\title{
The clinical value of TURP in patients with elevated or rising $P S A=D e$ klinische waarde van TURP bij patiënten met een verhoogde of stijgende PSA waarde
}

Citation for published version (APA):

van Renterghem, K. M. L. E. (2009). The clinical value of TURP in patients with elevated or rising $P S A=D e$ klinische waarde van TURP bij patiënten met een verhoogde of stijgende PSA waarde. [Doctoral Thesis, Maastricht University]. Maastricht University. https://doi.org/10.26481/dis.20090402kr

Document status and date:

Published: 01/01/2009

DOI:

$10.26481 /$ dis.20090402kr

Document Version:

Publisher's PDF, also known as Version of record

Please check the document version of this publication:

- A submitted manuscript is the version of the article upon submission and before peer-review. There can be important differences between the submitted version and the official published version of record.

People interested in the research are advised to contact the author for the final version of the publication, or visit the DOI to the publisher's website.

- The final author version and the galley proof are versions of the publication after peer review.

- The final published version features the final layout of the paper including the volume, issue and page numbers.

Link to publication

\footnotetext{
General rights rights.

- You may freely distribute the URL identifying the publication in the public portal. please follow below link for the End User Agreement:

www.umlib.nl/taverne-license

Take down policy

If you believe that this document breaches copyright please contact us at:

repository@maastrichtuniversity.nl

providing details and we will investigate your claim.
}

Copyright and moral rights for the publications made accessible in the public portal are retained by the authors and/or other copyright owners and it is a condition of accessing publications that users recognise and abide by the legal requirements associated with these

- Users may download and print one copy of any publication from the public portal for the purpose of private study or research.

- You may not further distribute the material or use it for any profit-making activity or commercial gain

If the publication is distributed under the terms of Article 25fa of the Dutch Copyright Act, indicated by the "Taverne" license above, 


\section{The clinical value of TURP in patients with elevated or rising PSA}

Koenraad M. L. E. van Renterghem 
Copyright@ 2009 - KMLE van Renterghem - Maastricht 


\section{The clinical value of TURP in patients with elevated or rising PSA}

\section{De klinische waarde van TURP bij patiënten met een verhoogde of stijgende PSA waarde}

Proefschrift ter verkrijging van de graad van doctor aan de Universiteit Maastricht op gezag van de Rector Magnificus Prof mr G.P.M.F. Mols en volgens besluit van het College van Decanen

op 2 april 2009 om 14 uur door Koenraad Maria Leon Estella van Renterghem. 
Promotor:

Co-promotor:

Beoordelingscommissie: Prof. Dr. A.P. de Bruïne, voorzitter

Prof. Dr. V.C.G. Tjan-Heijnen

Prof. Dr. J.J.M.C.H. de la Rosette,

(Universiteit van Amsterdam)

Prof. Dr. O. van Schayck 
Si tibi videtur quod multa scis, et satis bene intellegis, scito tamen quia sunt multo plura quae nescis.

Als het u schijnt dat ge veel weet, en vrij goed begrijpt, weet dan dat er nog veel meer is dat gij niet weet (Thomas a Kempis ${ }^{\circ} \pm 1380-\dagger 1472$ ). 


\section{Table of contents}

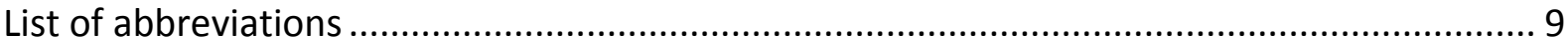

Chapter 1 - General introduction, background and outline of the thesis ............................. 11

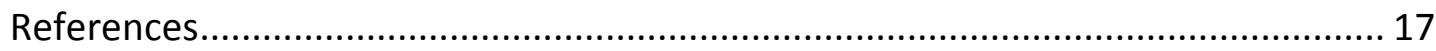

Chapter 2 - Rising PSA in patients with minor LUTS without evidence of prostatic carcinoma:

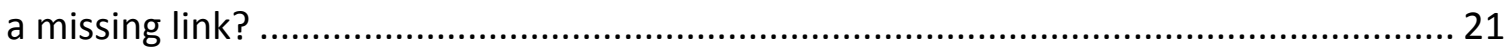

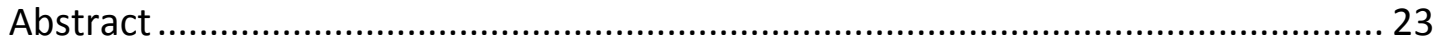

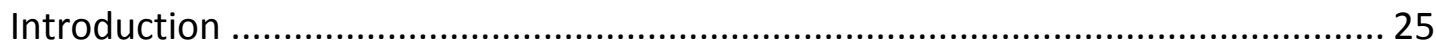

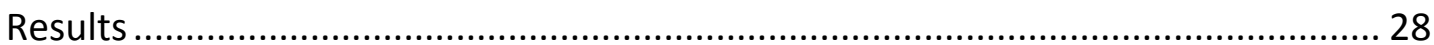

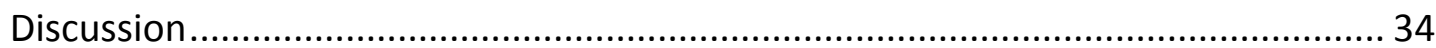

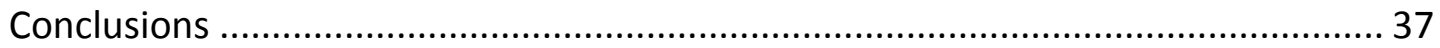

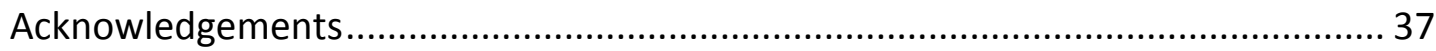

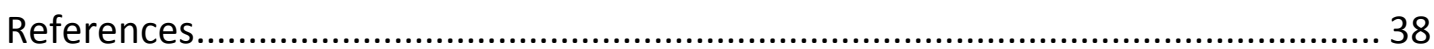

Chapter 3 - Clinical relevance of transurethral resection of the prostate in "asymptomatic"

patients with an elevated prostate-specific antigen level .............................................. 43

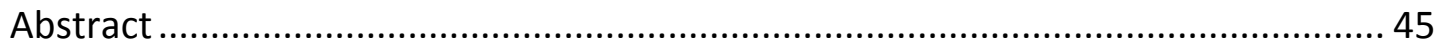

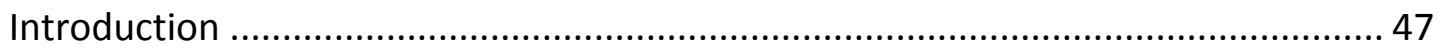

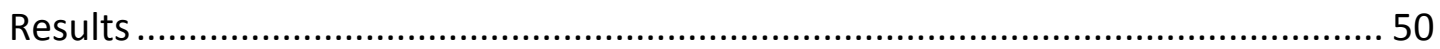

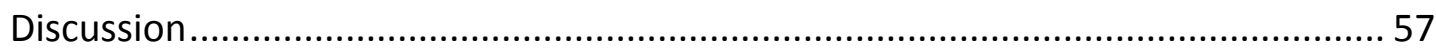

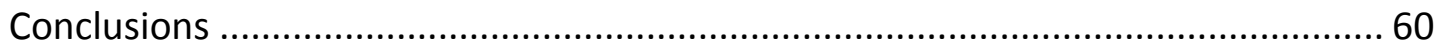

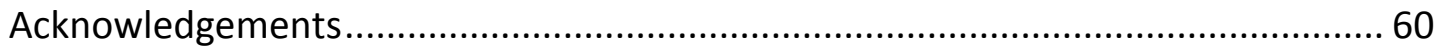

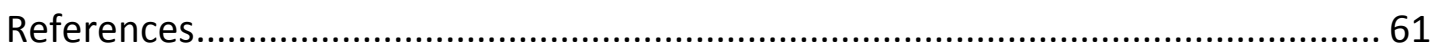

Chapter 4- Long-term clinical outcome of a diagnostic transurethral resection of the prostate

in patients with an elevated prostate-specific antigen level and minor lower urinary tract

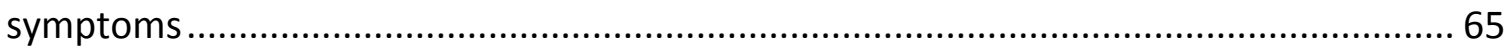

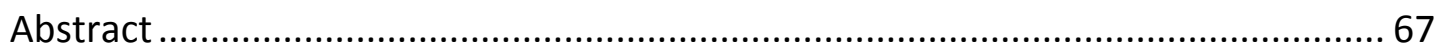

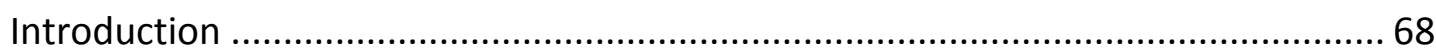

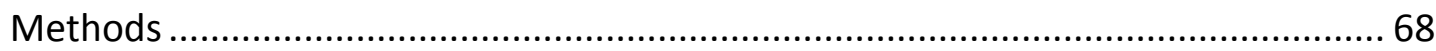

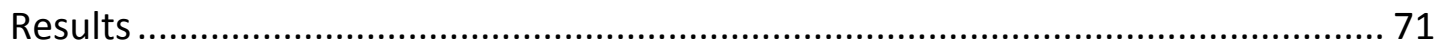

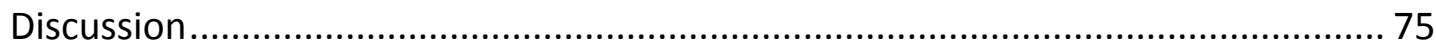

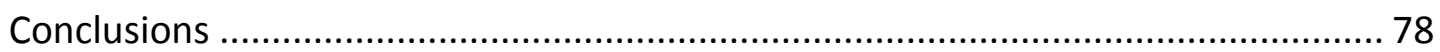

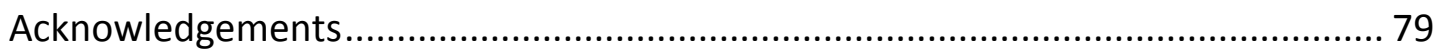

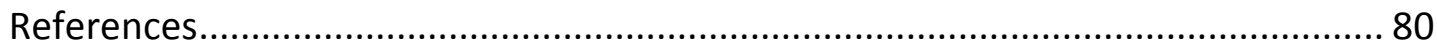

Chapter 5 - Prospective study of the role of transurethral resection of the prostate in patients with an elevated prostate specific antigen level, minor lower urinary tract

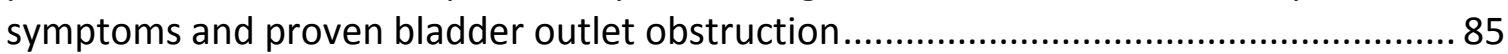

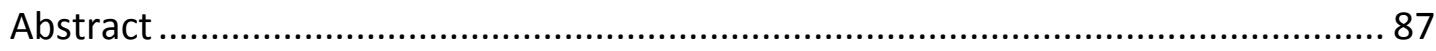

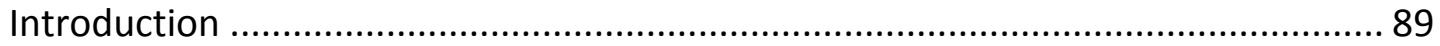

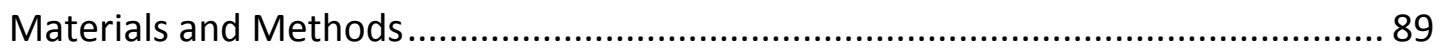

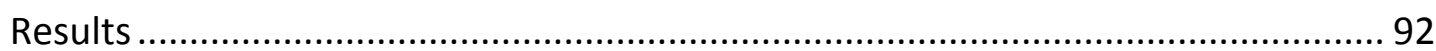

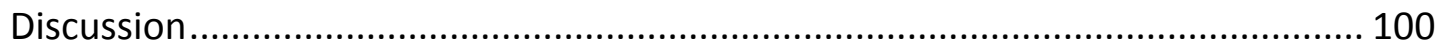

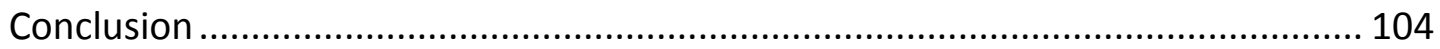

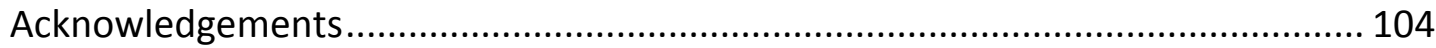

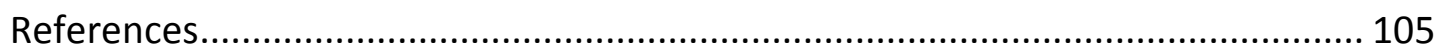


Chapter 6 - A new algorithm in patients with elevated and/or rising prostate-specific antigen level, minor lower urinary tract symptoms and negative multisite prostate biopsies... 109

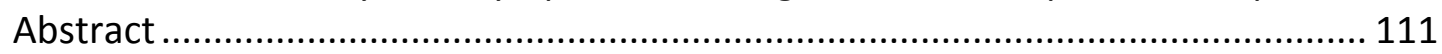

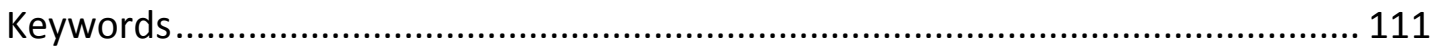

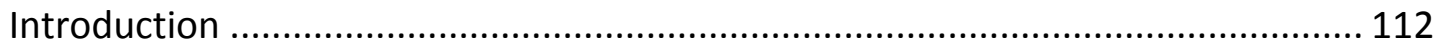

What are urologists doing today with patients presenting with elevated and/or rising PSA levels, minor LUTS and no signs of prostate cancer on (multiple) extended

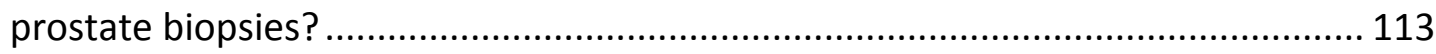

What has been suggested so far to deal with those patients?............................... 118

Proposal of a new algorithm in patients with elevated and/or rising PSA, minor LUTS, normal DRE and/or TRUS, and (multiple) negative extended prostate biopsies

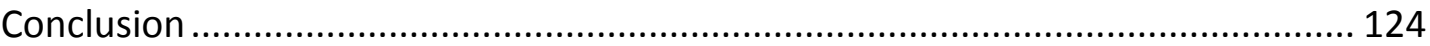

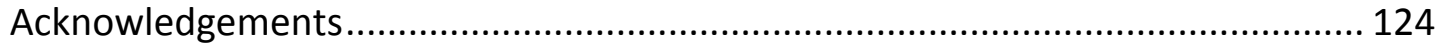

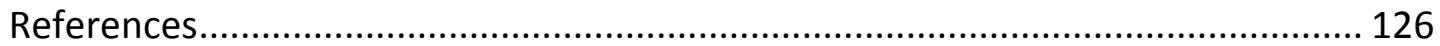

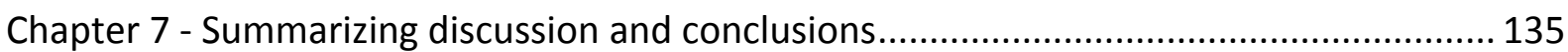

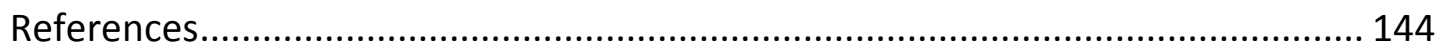

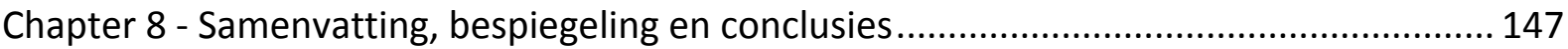

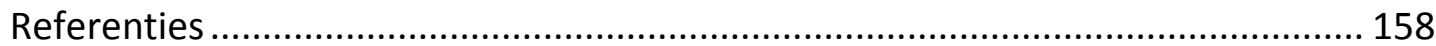

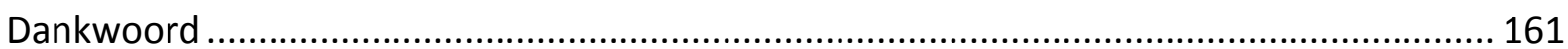

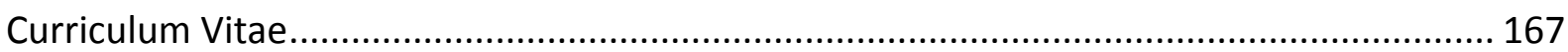




\section{List of abbreviations}

$\begin{array}{ll}\text { BOO: } & \text { Bladder Outlet Obstruction } \\ \text { BPE: } & \text { Benign Prostatic Enlargement } \\ \text { BPH: } & \text { Benign Prostatic Hyperplasia } \\ \text { BPSA: } & \text { Benign Prostate Specific Antigen } \\ \text { CEUS: } & \text { Contrast Enhanced Ultrasound } \\ \text { DRE: } & \text { Digital Rectal Examination } \\ \text { EPB: } & \text { Extended Prostate Biopsies } \\ \text { HPIN: } & \text { High Grade Prostatic Intra-epithelial Neoplasia } \\ \text { IPSS: } & \text { International Prostate Symptoms Score } \\ \text { LUTS: } & \text { Lower Urinary Tract Symptoms } \\ \text { PAP: } & \text { Prostate Acid Posphatase } \\ \text { PCa: } & \text { Prostate Cancer } \\ \text { PdetQ } & \text { Detrusor Pressure at Maximum flow } \\ \text { P/F: } & \text { Pressure / Flow } \\ \text { PSA: } & \text { Prostate Specific Antigen } \\ \text { PSAD: } & \text { Prostate Specific Antigen Density } \\ \text { PSA-Ratio (PSA\%): } & \text { Percentage of free PSA } \\ \text { PSAV: } & \text { Prostate Specific Antigen Velocity } \\ \text { QOL: } & \text { Quality Of Life } \\ \text { RRP: } & \text { Retropubic Radical Prostatectomy } \\ \text { RTE: } & \text { Real Time Elastography } \\ \text { SPSS: } & \text { Statistical Package for Social Sciences } \\ \text { TRUS: } & \text { Transrectal Ultrasound } \\ \text { TURP: } & \text { Transurethral Resection of the Prostate } \\ & \\ & \end{array}$


Chapter 1 - General introduction, background and outline of the thesis 
Benign prostatic hyperplasia (BPH) is a common condition in ageing men. As prostate enlargement is not always accompanied with symptoms, the exact prevalence of this condition is difficult to estimate. However, we surely know that clinical BPH is highly prevalent. In the Baltimore Longitudinal Study of Aging [1], it was shown that $60 \%$ of men aged 60 years or more have some degree of BPH. The Olmstead County Survey [2] estimated that in unselected Caucasian men in the United States over 70 years of age, $28 \%$ had moderate to severe lower urinary tract symptoms (LUTS). Furthermore, BPH is the second most common cause of surgical intervention in men over 60 years of age [3].

Prostate cancer on the other hand is diagnosed in 2.6 million new cases in Europe yearly. Bray [4] has proven that $11 \%$ of all male cancer cases in Europe were prostate cancers. Black [5] estimated that $9 \%$ of all cancer related deaths among men in Europe were due to prostate cancer. This implicates that prostate cancer is a health problem of the ageing male, especially in developed countries.

With the introduction of prostate specific antigen (PSA), a very interesting marker to diagnose prostate cancer became available as PSA is more sensitive than the formerly used prostate acid phosphatase (PAP) in detection of prostate cancer [6]. However, PSA is organ specific and not cancer specific. This implicates in many cases problems in diagnosing the nature of the prostatic disease. Stamey showed [6] a linear correlation between PSA values and prostate volume in BPH $(r=0.31)$.

Taking all these data together, it means that many patients are referred to an urologist because of elevated and/or rising PSA values. If PSA values are 
elevated and/or rising, if rectal examination and/or transrectal ultrasound are suspect for prostate cancer and extended multisite biopsies show malignancy, prostate cancer is diagnosed. In this case, treatment can be discussed with the patient according to the current guidelines. If however PSA values are elevated and/or rising, patient has no or minor LUTS, rectal examination and/or rectal ultrasound show no suspicion for prostate cancer and (multiple) extended prostate biopsies show no malignancy, uncertainty will arise.

In a recent publication on health perceptions in patients who undergo screening and work up for prostate cancer, Katz [7] showed that men with an abnormal prostate cancer screening report had an increased cancer related worry and more problems with sexual function. No one can find cancer; on the other hand, no one can reassure those patients. Similar findings were encountered in breast cancer screening [8][9]. So far, a lot of research is performed on what to do if patients present with elevated and/or rising PSA values, no LUTS, normal rectal examination and/or normal transrectal ultrasound, and negative (multiple) extended prostate biopsies. For example, PSA age related values or PSA density can be used [10]. Connolly [11] elaborated on the value of PSA velocity. Another refinement of PSA work up can be done with PSA ratio as shown by Laguna [10].

In the same group of patients with elevated and/or rising PSA, no LUTS, normal rectal examination and/or transrectal ultrasound and negative (multiple) extended prostate biopsies, one can try to refine diagnosis using different biopsy strategies. Hodge [12] performed research on a 6 core biopsy strategy. Arnold [13] promoted a 12 core biopsy scheme. More recently, Guichard [14] promoted the value of a 21 core biopsy strategy. Ultimately one can try to 
improve the diagnostic yield using saturation biopsies [15]. Another diagnostic dilemma is how many repeat biopsies should be done? Interesting work in this field was performed by Djavan [16][17]. Djavan showed that the chance to find cancer in the first biopsy session is $24 \%$. In a second biopsy session, $13 \%$ positive biopsies were encountered. After the second biopsy, diagnostic yield dropped dramatically.

If in these patients the PSA value remains elevated, one could wonder if inflammation could be the reason for PSA elevation. Many authors have proven that inflammation was not responsible for elevated PSA values $[18][19][20]$. Another ongoing discussion is the value of dietary manipulation; to our knowledge, no sound prospective, randomised placebo controlled trials have been published until now.

What is known about PSA in BPH patients? PSA is a marker for bladder outlet obstruction (BOO), a predictor of future prostate growth, a marker for elevated risk of acute urinary retention and PSA elevation is correlated with an augmented need for surgical therapy of BPH. All of these conditions have been proven to be present in patients with LUTS [21][22][23][24].

Nevertheless, the question remains what action to undertake in this group of patients if there is only minor LUTS. In this thesis we try to answer this question.

After this introduction, we discuss the results obtained in a retrospective analysis in patients with no bothersome LUTS (International Prostate Symptoms Score (IPSS) 0-7 or 8-19), elevated and/or rising PSA ( $\geq 4 \mathrm{ng} / \mathrm{ml}$ ), 
normal rectal examination and/or normal transrectal ultrasound and (multiple) negative prostate biopsies in Chapter 2. Special attention was given to urodynamic evaluation.

The results of the evaluation of the same group of patients with focus on TURP outcome with regard to symtomatology, PSA evolution and histological characteristics are shown in Chapter 3, while the results of a long term evaluation executed on the same group of patients are shown in Chapter 4.

In Chapter 5, the data obtained in a prospective analysis in a group of patients with the same characteristics are shown.

Chapter 6 deals with the proposal of a new algorithm to diagnose and treat patients with the above mentioned features.

Finally, in Chapter 7, we end with some summarizing discussion and conclusions. Chapter 8 consists of the Dutch translation of this summarizing discussion and conclusions. 


\section{References}

[1] Arrighi HM, Metter EJ, Guess HA, Fozzard JL. Natural history of benign prostatic hyperplasia and risk of prostatectomy, the Baltimore Longitudinal Study of Aging. Urology 1991;35(Suppl):4-8.

[2] Chute CG, Panser LA, Girman CJ, Oesterling JE, Guess HA, Jacobsen SJ, Lieber MM. The prevalence of prostatism: a population based survey of urinary symptoms. J Urol 1993;150(1):85-89.

[3] Kirby RS. The clinical assessment of benign prostatic hyperplasia. Cancer 1992;70(1 Suppl):284-290.

[4] Bray F, Sankila R, Ferlay J, Parkin DM. Estimates of cancer incidence and mortality in Europe in 1995. Eur J Cancer 2002;38(1):99-166.

[5] Black RJ, Bray F, Ferlay J, Parkin DM. Cancer incidence and mortality in the European Union: cancer registry data and estimates of national incidence for 1990. Eur J Cancer 1997;33(7):1075-1107.

[6] Stamey T, Yang N, Hay A, McNeal J, Freiha F, Redwine E. Prostate-specific antigen as a serum marker for adenocarcinoma of the prostate. N Eng J Med 1987;317(15): 909916.

[7] Katz D, Jarrard D, McHorney C, Hillis S, Wiebe D, Fryback D. Health perceptions in patients who undergo screening and workup for prostate cancer. Urology 2007;69:215-220.

[8] Lipkus IM, Halabi S, Strigo TS, Rimer BK. The impact of abnormal mammograms on psychosocial outcomes and subsequent screening. Psychooncology 2000;9(5):402-410.

[9] Aro AR, Pilvikki Absetz S, van Elderen TM, van der Ploeg E, van der Kamp LJ. Falsepositive findings in mammography screening induces short-term distress - breast cancer-specific concern prevails longer. Eur J Cancer 2000;36(9):1089-1097.

[10] Laguna P, Alivizatos G. Prostate specific antigen and benign prostatic hyperplasia. Curr Opin Urol 2000;10:3-8.

[11] Connolly D, Black A, Murray LJ, Napolitano G, Gavin A, Keane PF. Methods of Calculating Prostate-Specific Antigen Velocity. Eur Urol 2007;52:1044-1051.

[12] Hodge K, McNeal J, Terris M, Stamey T. Random systematic versus directed ultrasound guided transrectal core biopsies of the prostate. J Urol 1989; 142: 71-75. 
[13] Arnold P, Niemann T, Bahnson R. Extended sector biopsy for detection of carcinoma of the prostate. Urologic Oncology 2001;6:91-93.

[14] Guichard G, Larrré S, Gallina A, Lazar A, Faucon H, Chemama S, Allory Y, Patard J, Vordos D, Hoznek A, Yiou R, Salomon L, Abbou C, de la Taille A. Extended 21-sample needle biopsy protocol for diagnosis of prostate cancer in 1000 consecutive patients. Eur Urol 2007;52: 430-435.

[15] Ashley RA, Inman BA, Routh JC, Mynderse LA, Gettman MT, Blute ML. Reassessing the diagnostic yield of saturation biopsy of the prostate. Eur Urol 2008;53:976-983.

[16] Djavan B, Ravery V, Zlotta A, Dobronski P, Dobrovits M, Fakhari M, Seitz C, Susani M, Borkowski A, Boccon-Gibod L, Schulman CC, Marberger M. Prospective evaluation of prostate cancer detected on biopsies $1,2,3$ and 4: When should we stop? J Urol 2001;166: 1679-1683.

[17] Djavan B, Fong YK, Ravery V, Remzi M, Horninger W, Susani M, Kreuzer S, BocconGibod L, Bartsch G, Marberger M. Are repeat biopsies required in men with PSA levels $<$ or $=4 \mathrm{ng} / \mathrm{ml}$ ? A multiinstitutional prospective European study. Eur Urol $2005 ; 47(1): 38-44$

[18] Morote J, Lopez M, Encabo G, de Torres IM. Effect of inflammation and benign prostatic enlargement on total and percent free serum prostatic specific antigen. Eur Urol 2000;37:537-40.

[19] Nickel JC, Young DI, Boag S. Asymptomatic inflammation and/or infection in benign prostatic hyperplasia. BJU Int 1999;84:976-981.

[20] Chang S, Kim C, Jeon S, Kim Y and Choi B. Is chronic inflammatory change in the prostate the major cause of rising serum prostate-specific antigen in patients with clinical suspicion of prostate cancer? Int J Urol 2006;13(2):122-126.

[21] Laniado M, Ockrim J, Marronaro A, Tubaro A, Carter S. Serum prostate-specific antigen to predict the presence of bladder outlet obstruction in men with urinary symptoms. BJU Int 2004; 94(9):1283-1286.

[22] Roehrborn C, McConnell J, Lieber M, Kaplan S, Geller J, Malek G, Castellanos R Coffield S, Saltzman B, Resnick M, Cook TJ, Waldstreicher J. Serum prostate-specific antigen concentration is a powerful predictor of acute urinary retention and need for surgery in men with clinical benign prostatic hyperplasia. Urology 1999;53(3): 473-480. 
[23] Roehrborn C, McConnell J, Bonilla J, Rosenblatt S, Hudson P, Malek G, Castellanos R, Coffield S, Saltzman B, Resnick M, Cook TJ, Waldstreicher J. Serum prostate specific antigen is a strong predictor of future prostate growth in men with benign prostatic hyperplasia. J Urol 2000; 163(1): 13-20.

[24] Mochtar CA, Kiemeney LALM, Laguna MP, van Riemsdijk MM, Barnett GS, Debruyne FMJ, de la Rosette JJMCH. Prognostic role of prostate-specific antigen and prostate volume for the risk of invasive therapy in patients with benign prostatic hyperplasia initially managed with alpha1-blockers and watchful waiting. J Urol 2005;65(2): 300305. 
Chapter 2 - Rising PSA in patients with minor LUTS without evidence of prostatic carcinoma: a missing link?

van Renterghem K, Van Koeveringe G, Van Kerrebroeck P. Int Urol Nephrol. 2007;39(4):1107-1113. 


\section{Abstract}

Objectives:

To determine the role of pressure flowmetry in patients without bothersome lower urinary tract symptoms (LUTS), rising prostate-specific antigen (PSA) levels and diagnosed as having clinical benign prostatic hyperplasia (BPH) after negative (multiple) extended multi-site biopsy.

\section{Methods:}

The study enrolled patients with minor LUTS who were referred to our urological practice by their general practitioner because of a rising PSA level ( $\geq$ $4 \mathrm{ng} / \mathrm{mL}$ ). After exclusion of clinical prostatic carcinoma by digital rectal examination and transrectal ultrasound, all patients underwent at least one set of extended multi-site biopsies to exclude T1c prostate cancer. Patients with negative biopsies (clinical BPH) were subjected to pressure flowmetry whereafter those with bladder outlet obstruction underwent TURP.

\section{Results:}

The study included 82 patients, with a mean age of 64.8 years (50.2-78.2 years), satisfying the inclusion criteria. Urodynamic analysis showed that all patients had bladder outlet obstruction. After TURP, eight patients (9.8\%) were diagnosed as having histologically proven prostate cancer; 74 patients $(90.2 \%)$ were diagnosed as having $\mathrm{BPH}$. Patients of the BPH group had a mean preoperative PSA level of $8.8 \mathrm{ng} / \mathrm{mL}(4.3-25.8 \mathrm{ng} / \mathrm{mL})$ and a mean International Prostate Symptom Score of 8.8 (2-18). The mean detrusor pressure at maximum flow in $\mathrm{BPH}$ patients was $89.5 \mathrm{~cm} \mathrm{H}_{2} \mathrm{O}\left(20-200 \mathrm{~cm} \mathrm{H}_{2} \mathrm{O}\right)$.

\section{Conclusions:}

An increased PSA in patients with minor or no LUTS, clinical BPH and negative extended multi-site prostate biopsy is strongly correlated to bladder outlet 
obstruction. Therefore, patients with these characteristics should be treated with TURP.

Keywords: Benign prostatic hyperplasia, lower urinary tract symptoms, pressure flowmetry, prostate cancer, prostate-specific antigen, transurethral resection of the prostate 


\section{Introduction}

Twenty five percent of men over 50 years old have lower urinary tract symptoms (LUTS). LUTS may be caused by benign prostatic hyperplasia (BPH), one of the most common diseases among ageing men and the second most common cause of surgery in men over 60 years old [1]. Another cause of LUTS may be prostate cancer ( $\mathrm{PCa}$ ), which has become the most common cancer in males in several developed countries, especially in Western populations and particularly among the black population of the US.

Many patients are referred to a urological practice because of an elevated prostate-specific antigen (PSA) level. Because of its organ-specificity, PSA has become a useful marker in prostate screening [2]. It is exclusively produced in the prostate and more sensitive than prostatic acid phosphatase (PAP) in the detection of PCa; however, it is not cancer specific [2]. One of the major problems is the poor specificity at the upper cut-off levels. In a study of Ercole, $21 \%$ of patients undergoing transurethral resection of the prostate (TURP) because of BPH, had a PSA level $>4 \mathrm{ng} / \mathrm{mL}, 3 \%$ of these patients had a PSA level $>10 \mathrm{ng} / \mathrm{mL}$ [3]. Patients with an elevated PSA level are usually examined by digital rectal examination (DRE), transrectal ultrasound (TRUS) and extended multi-site biopsy to discriminate between PCa and BPH.

If left untreated, BPH may ultimately lead to bladder outlet obstruction (BOO). BOO can be demonstrated by urodynamic investigation with pressure flowmetry [4]. It has repeatedly been shown that BOO results in high detrusor pressure during micturition [1][5]. This can ultimately cause an increase in residual urine volume and a decline in bladder sensation [1]. In a number of patients, BOO will ultimately cause detrusor decompensation because the 
detrusor muscle has a tendency to fatigue. As detrusor hypertrophy may be reversible, detrusor pressure may fall to normal levels after TURP. It is well recognised that not all patients with BPH develop BOO. However, there is ample evidence that an increased prostate volume and elevated PSA level are associated with an increased risk of acute urinary retention and a greater need for invasive therapy [6-8]. In the present study, we evaluated the risk of BOO in BPH patients with minor LUTS and rising PSA levels.

\section{Methods}

The study was approved by the hospital's Ethics Committee and conducted according to the established good clinical practice criteria.

\section{Study population}

The study enrolled patients without bothersome LUTS who were referred to a specialist by their general practitioner because of an elevated PSA level $(\geq 4$ $\mathrm{ng} / \mathrm{mL}$ ). Patients with urinary tract infections and/or suspected DRE and/or suspected TRUS were excluded from the study.

\section{Study Design}

Previously collected data of patients were examined in a retrospective analysis. Patients with no complaints of LUTS and an elevated PSA ( $\geq 4 \mathrm{ng} / \mathrm{mL})$ who were referred by their general practitioner to our department were first evaluated by means of DRE and TRUS. Subsequently, all patients underwent at least one set of extended multi-site biopsies to detect T1c PCa. Patients with negative biopsies were subjected to pressure flowmetry. When BOO was diagnosed, patients underwent TURP. Resected tissue fragments were weighted and carefully examined for histologic evidence of PCa. Because all patients were 
referred by their general practitioner, PSA tests were carried out in different laboratories. DRE, TRUS and determination of International Prostate Symptom Score (I-PSS) (adapted from file) were all performed by one single wellexperienced urologist, i.e. the main investigator.

\section{Study procedures}

TRUS was carried out with a Kretz Ultrasound type combison 310 A+. Patients were considered unobstructed at a detrusor pressure at maximum flow $\left(P d e t Q_{\max }\right)<20 \mathrm{~cm} \mathrm{H}_{2} \mathrm{O}$, a Pdet $Q_{\max }$ between 20 and $40 \mathrm{~cm} \mathrm{H}_{2} \mathrm{O}$ was considered equivocal and patients with a $P \operatorname{det} Q_{\max } \geq 40 \mathrm{~cm} \mathrm{H} \mathrm{H}_{2} \mathrm{O}$ were considered to be obstructive. Biopsies were performed with a spring-loaded automatic biopsy gun (Bard magnum) fitted with a 18 gauge Tru-cut needle guided by a side firing transrectal probe US $7.5 \mathrm{mHz}$ bipolar. All patients received quinolone prophylaxis for five days, starting the day before the biopsy. No local anaesthesia was used. Prostate biopsies were handled and reported as proposed by the European society of uropathology [9]. Urodynamics were performed by an experienced nurse using Laborie Medical technologies INC/UDS-64-IIs. Patients received low dose quinolone prophylaxis for 48 hours, starting one day before the urodynamic study. Filling was done standing with a filling speed of $35 \mathrm{~mL} / \mathrm{min}$, using a 6 French filling catheter (double lumen). Pressure flow analysis was carried out in standing position according to the International Continence Society (ICS) criteria (Abrams-Griffiths score) [4]. All endoscopic procedures were done under loco-regional anaesthesia by the main investigator using an Olympus resectoscope 26 or 28 charrière, depending on estimated prostate volume. After TURP, resected prostate specimens were embedded until four sets, each containing $2 \mathrm{~g}$ of tissue, were filled. In case $>8$ 
$\mathrm{g}$ of resected prostate tissue, one additional cassette for each additional $10 \mathrm{~g}$ of tissue was filled [10].

\section{Statistical Methods}

All statistical analyses were performed using the routines of the Statistical Package for Social Sciences (SPSS) software. Two groups of patients were compared using the independent samples t-test. A $P$ value $<0.05$ was considered to indicate statistical significance.

\section{Results}

Number of patients and baseline characteristics

Of those patients satisfying the inclusion criteria of no bothersome LUTS and a PSA $\geq 4 \mathrm{ng} / \mathrm{mL}, 82$ had at least one set of negative extended multi-site biopsies. After TURP, eight out of 82 patients (9.8\%) had histologically proven PCa; 74 patients $(90.2 \%)$ had histologically proven BPH. Most of the results in this article are deducted from the figures of the BPH group.

Patient baseline characteristics are shown in Table 2.1. The mean age of all patients correlated well with that of the BPH group. Thirty seven BPH patients (50\%) had a PSA between 6 and $10 \mathrm{ng} / \mathrm{mL} ; 22$ BPH patients (29.7\%) had a PSA > $10 \mathrm{ng} / \mathrm{mL}$.

Table 2.1: Patient baseline characteristics.

\begin{tabular}{lll}
\hline & All patients $(\mathbf{n}=\mathbf{8 2})$ & BPH patients $(\mathbf{n}=\mathbf{7 4})$ \\
\hline Mean age (years) & $64.8(50.2-78.2)$ & $64.6(50.2-78.2)$ \\
Mean pre-operative PSA & $8.8(4.3-25.8)$ & $8.8 \mathrm{ng} / \mathrm{mL}(4.3-25.8)$ \\
Mean number of biopsy procedures & $1.7(1-6)$ & $1.6(1-6)$ \\
Mean pre-operative I-PSS & $8.5(0-18)$ & $8.8(2-18)$ \\
\hline
\end{tabular}


None of the BPH patients had severe LUTS (I-PSS > 19), 43 patients $(58.1 \%)$ had moderate symptoms (I-PSS 8-19) and 31 patients (41.9\%) had mild symptoms $($ I-PSS $\leq 7)$ (Figure 2.1). No patients were referred because of LUTS and none of the patients was spontaneously complaining of LUTS. The average I-PSS was 8.8 (2-18) (Figure 2.2). There was a negative correlation between I-PSS and PSA levels $(R=-0.3782, P<0.001)$. Both I-PSS and PSA levels normalised after TURP in all patients.

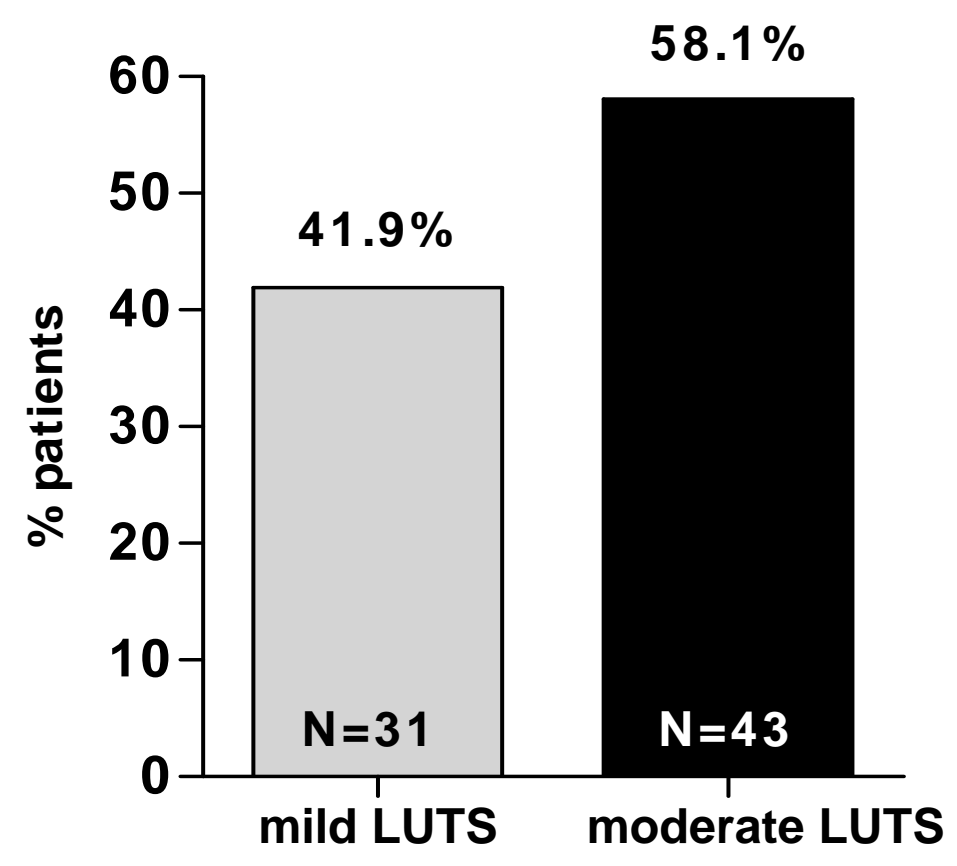

Figure 2.1: Percentage of benign prostatic hyperplasia (BPH) patients with mild (I-PSS $\leq 7)$ or moderate (I-PSS 8-19) lower urinary tract symptoms (LUTS) at baseline. 


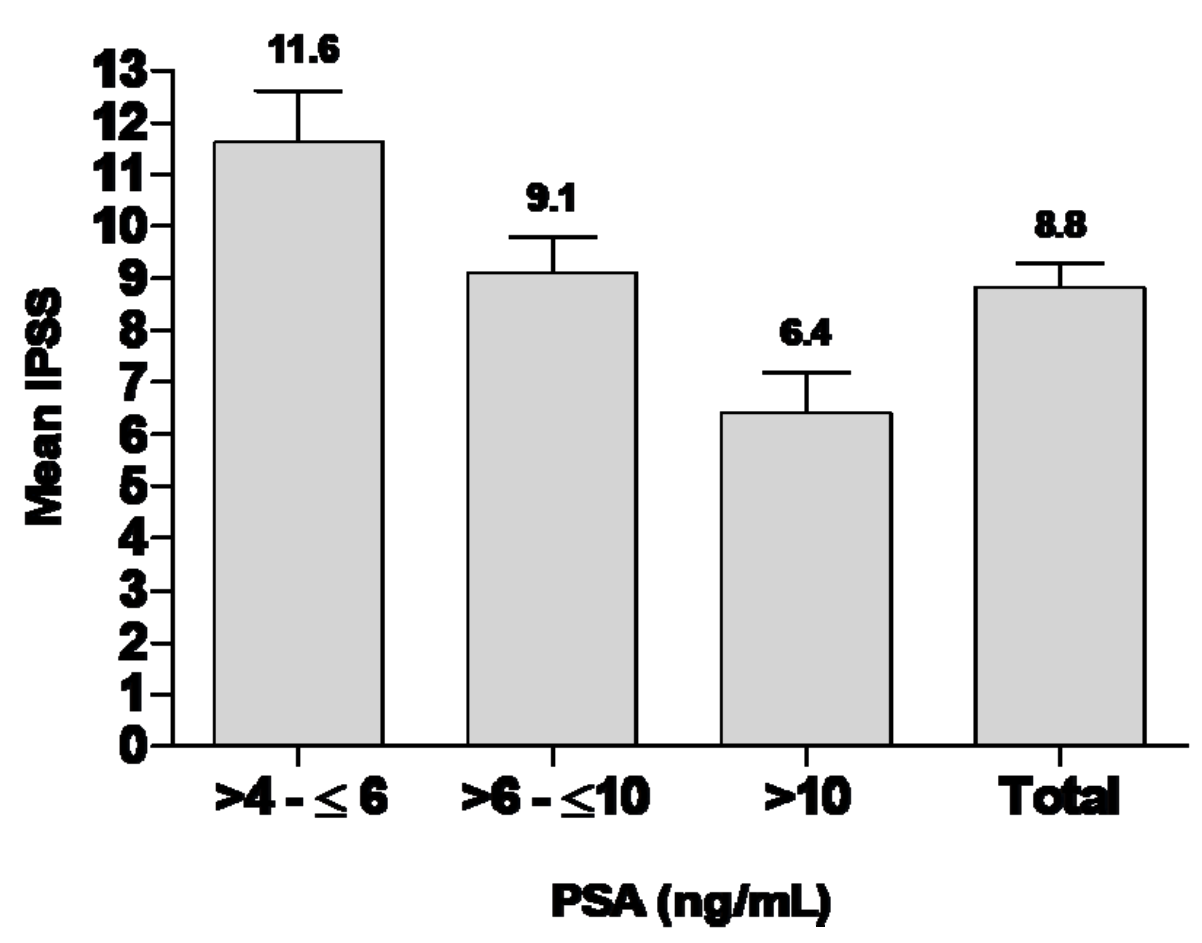

Figure 2.2: Mean International Prostate Symptom Score (I-PSS) (SE) within different Prostate-specific antigen (PSA) categories and in the total population of benign prostatic hyperplasia (BPH) patients at baseline.

\section{Urodynamic analysis}

Only three BPH patients (4.1\%) had an equivocal detrusor pressure at maximum flow ( $\mathrm{PdetQ}_{\max } 20$ to $39 \mathrm{~cm} \mathrm{H}_{2} \mathrm{O}$ ) at baseline; in this group cystoscopy showed obstruction. In two of these patients, the Watts factor could be reconstructed and showed normal detrusor contractility; in one patient the Watts factor could not be reconstructed. Seventy one patients $(95.9 \%)$ were clearly obstructed ( $P \operatorname{det} Q_{\max } \geq 40 \mathrm{~cm} \mathrm{H}_{2} \mathrm{O}$ ) (Figure 2.3). Mean $P \operatorname{det} Q_{\max }$ was $89.5 \mathrm{~cm} \mathrm{H} \mathrm{H}_{2}\left(20-200 \mathrm{~cm} \mathrm{H}_{2} \mathrm{O}\right)$ (Figure 2.4). Of the patients with a slightly elevated PSA ( $>4$ to $\leq 6 \mathrm{ng} / \mathrm{mL}$ ), $73.3 \%$ had an overactive bladder with urodynamic signs of detrusor overactivity. Of the patients with a PSA $>10$ 
$\mathrm{ng} / \mathrm{mL}, 68.2 \%$ had stable cystometry. The number of patients with stable vs. unstable cystometry was significantly different between both groups $(P=$ 0.021). The $P \operatorname{det} Q_{\max }$ was not statistically significantly correlated with $P S A$ levels $(P=0.364$; Figure 2.4$)$, age $(P=0.446)$ or I-PSS $(P=0.315)$.

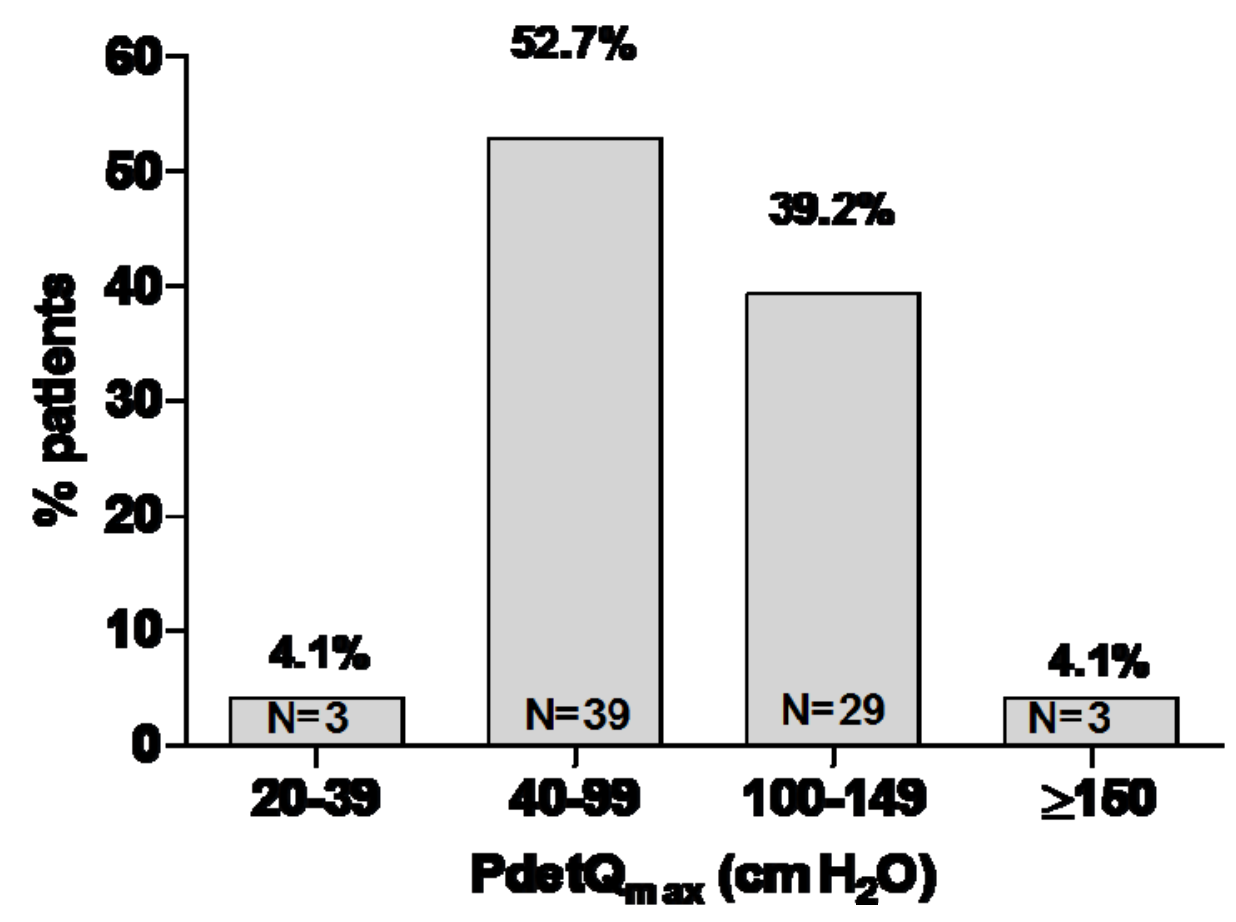

Figure 2.3: Percentage of benign prostatic hyperplasia (BPH) patients within different categories of detrusor pressure at maximum flow $\left(\mathrm{Pdet}_{\max }\right)$ at baseline. 


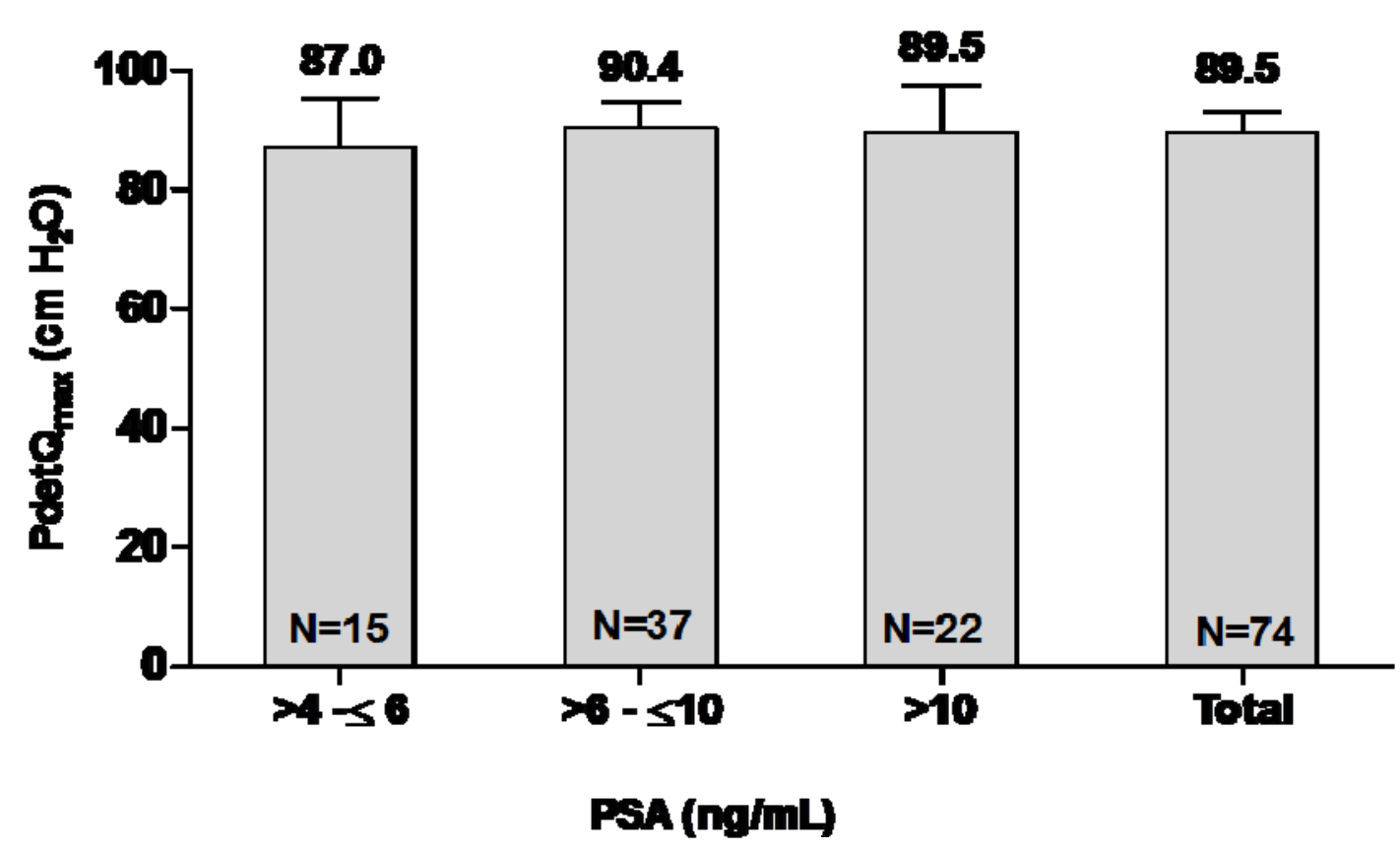

Figure 2.4: Detrusor pressure at maximum flow $\left(P \operatorname{det} Q_{\max }\right)(\mathrm{SE})$ in benign prostatic hyperplasia (BPH) patients within different prostate-specific antigen (PSA) categories.

\section{Prostate weight and histology}

After TURP, all resected specimen was carefully weighted and histologically examined. Eight out of 82 patients (9.8\%) were found to have PCa; seven of these patients (87.5\%) had clinically important PCa. One patient with T1aG2 was assigned to watchful waiting because this cancer has a low malignant potential (Gleason score $3+3=6$ ). The mean prostate weight (after TURP) was $44.2 \mathrm{~g}$ (13-100 g). Prostate weight varied considerably between BPH patients (Figure 2.5) and was positively correlated with PSA levels $(P=0.003, \mathrm{R}=$ 0.3199) and $P \operatorname{det} Q_{\max }(P=0.011, R=0.2656)$, but there was no statistically significant relation between prostate weight and I-PSS score $(P=0.189)$ or overactive bladder $(P=0.176)$. 


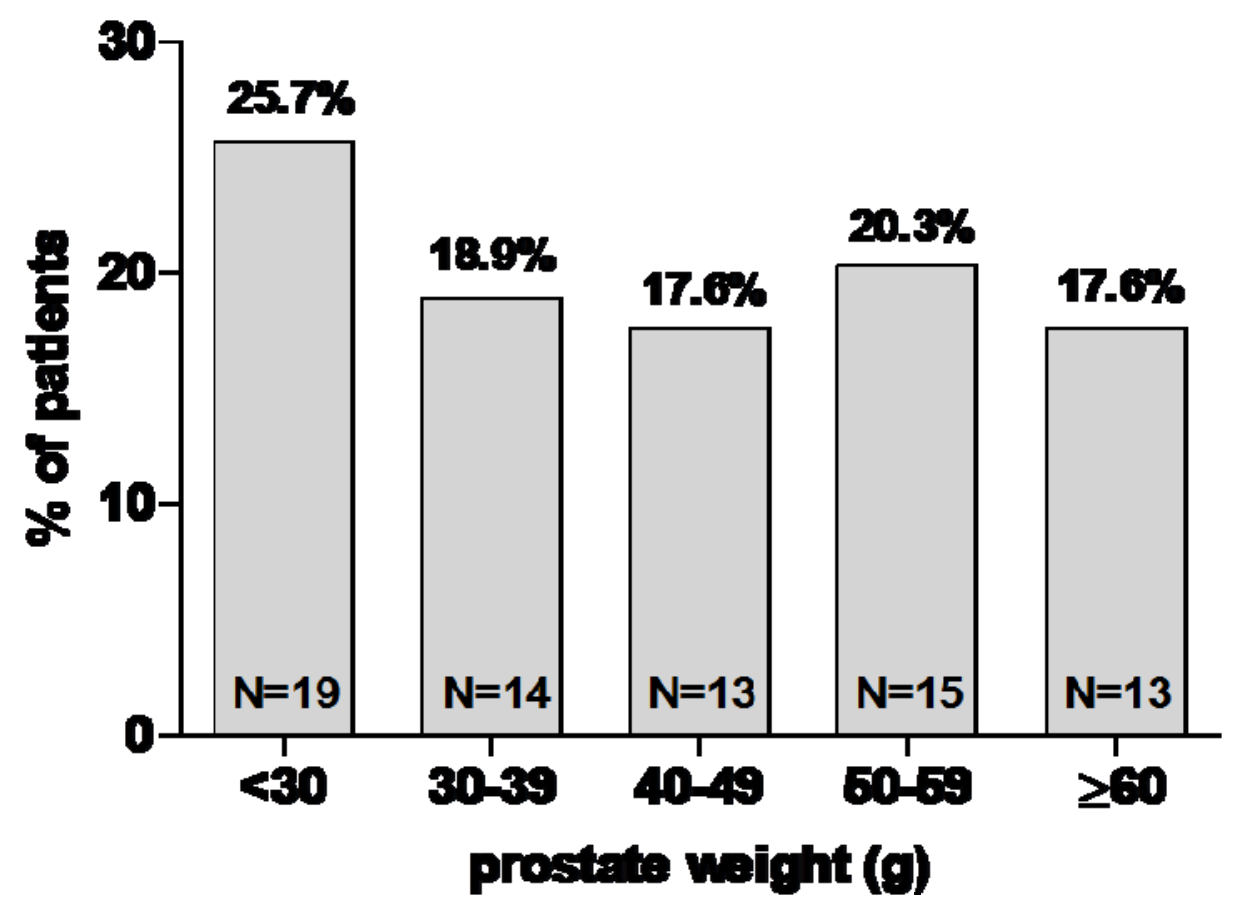

Figure 2.5: Percentage of benign prostatic hyperplasia (BPH) patients within different categories of prostate weight. 


\section{Discussion}

Patients with a continuously rising PSA level without evidence of PCa, even after (multiple) extended multi-site prostate biopsy, are a challenging diagnostic problem that occurs quite often in a urological practice. Especially when there are minor or no urinary symptoms, patients and their general practitioners and urologists are worried and anxious that the patient might develop PCa.

In the current study, all patients were referred by their general practitioner because of an elevated PSA level ( $>4 \mathrm{ng} / \mathrm{mL}$ ); none of them was referred because of bothersome LUTS. In patients where DRE and TRUS did not indicate malignancy, at least one set of extended multi-site prostate biopsies was performed to screen for T1c PCa. It is common practice to repeat prostate biopsies after a certain time if the first set of biopsies showed no malignancy. Sometimes patients with an elevated PSA level and negative biopsy are given chemoprevention or antibiotics hoping that this will normalise their PSA level. Although minor complications of extended multi-site biopsies are very common, severe complications are rather rare (3.5\% fever; $0.4 \%$ acute urinary retention; $0.5 \%$ hospital admittance because of sepsis) [11]. However, besides the fact that a prostate biopsy is an unpleasant examination for the patient, there is no scientific reason to repeat prostate biopsies ad aeternam. Djavan et al showed that the cancer detection rate in patients with a PSA level between 4 and $10 \mathrm{ng} / \mathrm{mL}$ is $22 \%$ on the first biopsy and $10 \%$ on the second biopsy [12][13]. Biopsy 3 and 4 had slightly higher complication rates than the first two biopsies and cancer detected on biopsies 3 and 4 had a lower Gleason score, volume and stage. Many authors tried to optimise the biopsy regimen to increase the 
diagnostic power [14][15][16][17]. In the present study, the average number of biopsy sets was 1.6; no serious complications were reported.

It has previously been shown that high PSA levels in patients with bothersome LUTS are associated with an augmented risk of acute urinary retention and BPH related surgery [6][8][18]. In the present study, urodynamic investigation showed that all patients had BOO, suggesting that a PSA level $\geq 4 \mathrm{ng} / \mathrm{mL}$ is also an important indication of $\mathrm{BOO}$ in patients presenting to their general practitioner without bothersome LUTS. We suggest that a high intravesical permictional detrusor pressure is a reason for rising PSA levels, even without major complaints [19]. Urodynamic investigation, especially with a low regimen of antibiotic prophylaxis, can be considered as a minimally invasive procedure for the diagnosis of $\mathrm{BOO}$ with a low complication rate [20].

Since all patients were found to be obstructed, all of them underwent TURP. TURP is indicated in the first place in patients with $\mathrm{BOO}$ because high detrusor pressure can lead to detrusor hypertrophy and ultimately to hypocontractility [5]. Detrusor hypertrophy has been shown to be a reversible process and the risk of detrusor fatigue diminishes after TURP [5]. Rodriguez showed that the clinical benefit of TURP is greater in patients who are more severely obstructed [21].

A second reason why patients were offered TURP is because histological analysis of tissue samples from the transition zone of the prostate allows detection of PCa that could not be detected after (multiple) extended multi-site biopsies. According to McNeal, $24 \%$ of PCas are located in the transition zone [22]. Greene showed that transition zone PCa is frequently associated with larger and high grade PCa in the peripheral zone [23]. Furthermore a subset of 
PCas located in the transition zone can be aggressive [24][25][26]. To date, there have been no studies investigating the diagnostic yield of $\mathrm{PCa}$ in men with minor LUTS [27][28]. In the current study, eight out of 82 patients $(9.8 \%)$ were histologically diagnosed as having PCa; seven of these patients (87.5\%) had clinically important PCa.

The theory that the elevated PSA levels in the patients included in our study are due to an elevated $\mathrm{Pdet}_{\mathrm{max}}$ caused by $\mathrm{BOO}$ is supported by the finding that PSA levels normalised after TURP in all patients. Despite the clear correlation between elevated PSA levels and BOO in the patients included in this study, we believe that pressure flow urodynamics are still recommended to decide whether TURP is indicated. The patients in this study did not seek help because of bothering LUTS and an elevated PSA level on its own is no reason to perform TURP. While I-PSS is a subjective measure, urodynamics provide objective information which can be used to discuss the intervention with the patient.

Regression analysis revealed that there was a negative correlation between PSA levels and I-PSS, which can probably be explained by the fact that an elevated PSA level is caused by high pressure, resulting in a good flow, no dysuria, and consequently a low I-PSS. This theory is supported by a previous study showing that a normal maximum flow rate does not rule out obstruction [29]. The results of another study suggested that although the I-PSS is useful to evaluate symptom worsening or improvement over time, there is only a poor correlation between the I-PSS and obstruction [30]. Therefore, relative changes in the I-PSS over time may be more meaningful than the absolute I-PPS. This might also explain why all patients included in the present study were 
obstructed, but none of them had severe LUTS. Finally, we found a positive correlation between PSA levels and prostate weight (after TURP).

\section{Conclusions}

The present study shows that there is a scientific basis for pressure flow studies in patients with a rising PSA level, with minor or no complaints of LUTS and after (multiple) negative extended multi-site biopsies because (nearly) all these patients are found to be obstructive. The elevated PSA in obstructed patients is probably due to a chronically elevated intravesical pressure. De-obstruction, i.e. TURP, can be indicated in these patients with BPH and rising PSA as it allows extensive histological examination of the transition zone of the prostate, thus providing more certainty about the diagnosis and reducing the fear of PCa, which is often associated with elevated PSA levels.

Although patients in the present study were not referred because of LUTS, more than half appeared to have moderate LUTS when they completed the IPSS. This implies that intravesical permictional pressure is to be considered uncomfortable for the patient.

\section{Acknowledgements}

The authors are grateful to Ismar Healthcare NV for their assistance in editing of the manuscript. 


\section{References}

[1] Kirby RS (1992) The clinical assessment of benign prostatic hyperplasia. Cancer 70:284-290.

[2] Stamey TA, Yang N, Hay AR, et al (1987) Prostate-specific antigen as a serum marker for adenocarcinoma of the prostate. N Engl J Med 317:909-916.

[3] Ercole CJ, Lange PH, Mathisen M, et al (1987) Prostatic specific antigen and prostatic acid phosphatase in the monitoring and staging of patients with prostatic cancer. $J$ Urol 138:1181-1184.

[4] Griffiths D, Hofner K, van Mastrigt R, et al (1997) Standardization of terminology of lower urinary tract function: pressure-flow studies of voiding, urethral resistance, and urethral obstruction. International Continence Society Subcommittee on Standardization of Terminology of Pressure-Flow Studies. Neurourol Urodyn 16:1-18.

[5] Claridge M, Shuttleworth KE (1964) The dynamics of obstructed micturition. Invest Urol 25:188-199.

[6] Marberger MJ, Andersen JT, Nickel JC, et al (2000) Prostate volume and serum prostate-specific antigen as predictors of acute urinary retention. Combined experience from three large multinational placebo-controlled trials. Eur Urol 38:563568.

[7] Tubaro A, La Vecchia C (2004) The relation of lower urinary tract symptoms with lifestyle factors and objective measures of benign prostatic enlargement and obstruction: an Italian survey. Eur Urol 45:767-772.

[8] Mochtar CA, Kiemeney LA, Laguna MP, et al (2005) Prognostic role of prostatespecific antigen and prostate volume for the risk of invasive therapy in patients with benign prostatic hyperplasia initially managed with alpha1-blockers and watchful waiting. Urology 65:300-305.

[9] Boccon-Gibod L, van der Kwast TH, Montironi R, et al (2004) Handling and pathology reporting of prostate biopsies. Eur Urol 46:177-181.

[10] Rosai J (2004) Ackerman's surgical pathology. ed. 9, Mosby Year Book. St. Louis

[11] Raaijmakers R, Kirkels WJ, Roobol MJ, et al (2002) Complication rates and risk factors of 5802 transrectal ultrasound-guided sextant biopsies of the prostate within a population-based screening program. Urology 60:826-830. 
[12] Djavan B, Ravery V, Zlotta A, et al (2001) Prospective evaluation of prostate cancer detected on biopsies 1, 2, 3 and 4: when should we stop? J Urol 166:1679-1683.

[13] Djavan B, Fong YK, Ravery V, et al (2005) Are repeat biopsies required in men with PSA levels $<$ or $=4 \mathrm{ng} / \mathrm{ml}$ ? A Multiinstitutional Prospective European Study. Eur Urol 47:38-44.

[14] Chon CH, Lai FC, McNeal JE, et al (2002) Use of extended systematic sampling in patients with a prior negative prostate needle biopsy. J Urol 167:2457-2460.

[15] Durkan GC, Sheikh N, Johnson P, et al (2002) Improving prostate cancer detection with an extended-core transrectal ultrasonography-guided prostate biopsy protocol. BJU Int 89:33-39.

[16] Arnold MD, Niemann TH, Bahnson RR (2001) Extended sector biopsy for detection of carcinoma of the prostate. Urol Oncol 6:91-93.

[17] Eskew LA, Bare RL, McCullough DL (1997) Systematic 5 region prostate biopsy is superior to sextant method for diagnosing carcinoma of the prostate. J Urol 157:199202.

[18] Laniado ME, Ockrim JL, Marronaro A, et al (2004) Serum prostate-specific antigen to predict the presence of bladder outlet obstruction in men with urinary symptoms. BJU Int 94:1283-1286.

[19] Gerstenberg TC, Andersen JT, Klarskov P, et al (1982) High flow infravesical obstruction in men: symptomatology, urodynamics and the results of surgery. J Urol 127:943-945.

[20] Carter PG, Lewis P, Abrams P (1991) Urodynamic morbidity and dysuria prophylaxis. Br J Urol 67:40-41.

[21] Rodrigues P, Lucon AM, Freire GC, et al (2001) Urodynamic pressure flow studies can predict the clinical outcome after transurethral prostatic resection. J Urol 165:499502.

[22] McNeal JE, Redwine EA, Freiha FS, et al (1988) Zonal distribution of prostatic adenocarcinoma. Correlation with histologic pattern and direction of spread. Am J Surg Pathol 12: 897-906.

[23] Greene DR, Wheeler TM, Egawa S, et al (1991) A comparison of the morphological features of cancer arising in the transition zone and in the peripheral zone of the prostate. J Urol 146:1069-1076. 
[24] Shannon BA, McNeal JE, Cohen RJ (2003) Transition zone carcinoma of the prostate gland: a common indolent tumour type that occasionally manifests aggressive behaviour. Pathology 35:467-471.

[25] Radhakrishnan S, Dorkin TJ, Sheikh N, et al (2004) Role of transition zone sampling by TURP in patients with raised PSA and multiple negative transrectal ultrasound-guided prostatic biopsies. Prostate Cancer Prostatic Dis 7:338-342.

[26] Kitamura H, Masumori N, Tanuma Y, et al (2002) Does transurethral resection of the prostate facilitate detection of clinically significant prostate cancer that is missed with systematic sextant and transition zone biopsies? Int J Urol 9:95-99.

[27] Zigeuner R, Schips L, Lipsky K, et al (2003) Detection of prostate cancer by TURP or open surgery in patients with previously negative transrectal prostate biopsies. Urology 62:883-887.

[28] Bratt O (2006) The difficult case in prostate cancer diagnosis--when is a "diagnostic TURP" indicated? Eur Urol 49:769-771

[29] Abrams P, Blaivas J, Griffiths DJ, Nordling J, Koyanagi T, Neal D, et al. The objective evaluation of bladder outflow obstruction. In: Cockett ATK, Khoury S, Aso Y, Chatelain C, Denis L, Griffiths K, Murphy G, eds. Proceedings of the 2nd international consultation on benign prostatic hyperplasia. Jersey: Jersey Scientific Communication, 1993:153-209.

[30] Laguna P, Alivizatos G. Prostate specific antigen and benign prostatic hyperplasia. Curr Opin Urol 2000;10:3-8 
Chapter 3 - Clinical relevance of transurethral resection of the prostate in "asymptomatic" patients with an elevated prostatespecific antigen level

van Renterghem K, Van Koeveringe G, Achten R, Van Kerrebroeck P. Eur Urol. 2007 Sep;52(3):819-826. 


\section{Abstract}

Objectives:

To determine the clinical relevance of transurethral resection of the prostate (TURP) in patients with minor lower urinary tract symptoms (LUTS) but elevated prostate-specific antigen (PSA) levels.

\section{Methods:}

In this study, we retrospectively included 82 patients (50.2-78.2 years) with minor LUTS, elevated PSA ( $\geq 4 \mathrm{ng} / \mathrm{mL}$ ) and no signs of prostate cancer after (multiple) negative multisite biopsies who underwent TURP after they were diagnosed by urodynamics with bladder outlet obstruction (BOO). We evaluated the clinical benefit of TURP by assessing its effect on International Prostate Symptom Score (I-PSS) and PSA and the diagnostic value of histological examination of the resected tissue for the presence of PCa.

Results:

After TURP, histological analysis of the resected specimen revealed that eight patients $(9.8 \%)$ had prostate cancer (PCa); seven of these patients had a tumour that needed further treatment. The remaining 74 patients $(90.2 \%)$ were diagnosed with $\mathrm{BOO}$ due to $\mathrm{BPH} / \mathrm{BPE}$. In this group, the mean PSA level decreased from $8.8 \mathrm{ng} / \mathrm{mL}$ before TURP to $1.1 \mathrm{ng} / \mathrm{mL}$ in the first year and 1.3 $\mathrm{ng} / \mathrm{mL}$ in the second year after TURP; the mean I-PSS decreased from 8.8 to 1.5 in the first year after TURP.

\section{Conclusions:}

The current data suggest that patients with minor LUTS and elevated PSA without evidence of PCa are very likely to have BOO due to BPH/BPE and may benefit from TURP if obstruction is proved. However, a prospective trial is warranted to assess the impact of these results on clinical practice. 
Keywords: Benign prostatic enlargement, benign prostatic hyperplasia, diagnosis, lower urinary tract symptoms, prostate cancer, prostate-specific antigen, transition zone, transurethral resection of the prostate 


\section{Introduction}

Prostate-specific antigen (PSA) has proved to be a very useful tumour marker for the prostate gland. However, as PSA is not prostate cancer (PCa)-specific [1], especially at the upper cut-off levels, and early PCa is often asymptomatic, an elevated PSA level may be a major cause of concern for patients without clinical evidence of PCa. Therefore, many patients with minor or no LUTS are referred to a urologist because of an elevated PSA level. When there are no arguments for bladder outlet obstruction (BOO) and digital rectal examination (DRE) and transrectal ultrasound (TRUS) of the prostate shows no signs of malignancy, many of these patients are subjected to extended multisite biopsies to rule out T1C PCa. If biopsies do not show malignancy, patients are usually actively monitored with our without treatment with antibiotics, diet supplements, etc. In most cases, the PSA level is re-evaluated after a certain period of time and, if PSA is still elevated, a new set of biopsies is analysed [2]. When multiple negative biopsy procedures give no explanation for the elevated PSA level, uncertainty grows.

In the present paper we evaluated whether elevated PSA levels in patients with minor LUTS but no biopsy-proven PCa are due to BOO. In addition, we evaluated the diagnostic and symptomatic benefits of subsequent TURP in these patients.

\section{Methods}

The study was approved by the hospital's Ethics Committee and conducted according to the established good clinical practice criteria. 


\section{Study population}

The study retrospectively included all patients without bothersome LUTS with an elevated PSA ( $\geq 4 \mathrm{ng} / \mathrm{mL}$ ) and no signs of PCa by DRE and TRUS and (multiple) negative multisite biopsies who were referred to our department since January 1997. All these patients underwent a diagnostic TURP after they were diagnosed by urodynamics with BOO or equivocal detrusor pressure at maximum flow $\left(P \operatorname{det} \mathrm{Q}_{\max }\right)$. Patients with urinary tract infections and/or clinical PCa were excluded from the study. All patients were informed about the potential risks associated with the procedure.

\section{Study Design}

Patients with no bothersome LUTS who were referred by their general practitioner to our department because of an elevated PSA level ( $\geq 4 \mathrm{ng} / \mathrm{mL}$ ) were evaluated by means of DRE and TRUS and underwent at least one set of 12-core extended multi-site biopsies to exclude T1c PCa. Patients with no signs of malignancy were subjected to pressure flowmetry and those with BOO (Pdet $Q_{\max } \geq 40 \mathrm{~cm} \mathrm{H}_{2} \mathrm{O}$ ) or equivocal $P$ det $Q_{\max }$ (between 20 and $40 \mathrm{~cm} \mathrm{H} \mathrm{H}_{2} \mathrm{O}$ ) were treated with TURP. The clinical relevance of TURP in these patients was evaluated by assessing its effect on I-PSS and PSA and the diagnostic value of histological examination of the resected tissue for the presence of PCa. The International Prostate Symptom Score (I-PSS) was evaluated before and within the first year after TURP; PSA levels were evaluated pre-operatively and within the first and second year after TURP. Initial PSA tests were performed in different laboratories as all patients were referred by their general practitioner. Further examination was performed by the main investigator/urologist. This included DRE, TRUS, assessment of the patient's medical history with the I-PSS (adapted from file), extended 12-core multisite biopies and evaluation of post- 
operative PSA levels. Pressure flowmetry was performed by an experienced study nurse.

\section{Study procedures}

TRUS was performed using a Kretz Ultrasound type combison 310 At. 12-core biopsies were done with a spring-loaded automatic biopsy gun (Bard magnum) fitted with a 18 gauge Tru-cut needle guided by a side firing transrectal probe US $7.5 \mathrm{mHz}$ bipolar. The 12-core biopsy protocol was described in 2002 by Durkan et al. [3]. Briefly, 6 laterally targeted biopsies, 2 from the transition zone and 4 from the lateral peripheral zones were taken in addition to the conventional parasagittal sextant biopsies (at the base, mid gland and apical regions of the prostate). All biopsies were performed using this protocol. Patients received quinolone prophylaxis for five days, starting the day before the biopsy. No local anaesthesia was used. Prostate biopsies were handled and reported as proposed by the European society of uropathology [4]. Urodynamics were performed using Laborie Medical technologies INC/UDS-64Ils. All patients were treated with low dose quinolone prophylaxis for 48 hours, starting the day before urodynamics. Filling was done standing with a filling speed of $35 \mathrm{~mL} / \mathrm{min}$, using a 6 French filling catheter (double lumen). Pressure flow analysis occurred in agreement with the International Continence Society (ICS) criteria (Abrams-Griffiths score). Patients with a PdetQ $Q_{\max }<20 \mathrm{~cm} \mathrm{H} \mathrm{H}_{2} \mathrm{O}$ were considered unobstructed, those with a $P \operatorname{det} Q_{\max } \geq 40 \mathrm{~cm} \mathrm{H}_{2} \mathrm{O}$ were considered obstructed and a $P \operatorname{det} \mathrm{Q}_{\max }$ between 20 and $40 \mathrm{~cm} \mathrm{H} \mathrm{H}_{2} \mathrm{O}$ was considered equivocal. Endoscopic procedures were done under loco-regional anaesthesia using an Olympus resectoscope 26 or 28 charrière, depending on estimated prostate volume. After TURP, resected prostate fragments were weighed and carefully examined. Afterwards, the fragments were embedded 
until four sets, each containing $2 \mathrm{~g}$ of tissue, were filled. When there was an excess of prostate tissue, one additional cassette for each additional $10 \mathrm{~g}$ of tissue was filled [5].

\section{Statistical Methods}

All statistical analyses were performed using the routines of the Statistical Package for Social Sciences (SPSS) software. When two successive results were compared on the same patients, the paired samples t-test was used for variables for which the normality assumption was accepted; the nonparametric sign test was used for variables with no normal distribution. Two groups of patients were compared using the independent samples t-test when the normality assumption was accepted and the Mann-Whitney $U$ Test for variables with no normal distribution. A $P$ value $<0.05$ was considered to indicate statistical significance.

\section{Results}

\section{Number of patients and baseline characteristics}

Eighty two patients satisfied the inclusion criteria of no bothersome LUTS, a PSA $\geq 4 \mathrm{ng} / \mathrm{mL}$, no evidence of malignancy after DRE, TRUS and at least one set of negative 12-core extended multi-site biopsies. Nearly all patients were found to be obstructed; i.e. 3 patients had an equivocal pressure at maximum flow ( $P$ det $Q_{\max } 20$ to $39 \mathrm{~cm} \mathrm{H}_{2} \mathrm{O}$ ), 79 patients were clearly obstructed (PdetQ $Q_{\max } \geq 40$ $\mathrm{cm} \mathrm{H}_{2} \mathrm{O}$ ). When obstruction was proved, patients underwent TURP. After TURP, histological analysis showed that eight patients (9.8\%) had PCa; 74 patients (90.2\%) had BPH (including 71 patients with obstructed and three patients with equivocal pressure). 
Table 3.1: Baseline characteristics.

\begin{tabular}{lll}
\hline & All patients $(\mathbf{N}=\mathbf{8 2})$ & BPH/BPE patients $(\mathbf{N}=\mathbf{7 4})$ \\
\hline Mean age (years) & $64.8(50.2-78.2)$ & $64.6(50.2-78.2)$ \\
Mean pre-operative PSA $(\mathrm{ng} / \mathrm{mL})$ & $8.8(4.3-25.8)$ & $8.8(4.3-25.8)$ \\
$\begin{array}{l}\text { Mean number of biopsy } \\
\text { procedures }\end{array}$ & $1.7(1-6)$ & $1.6(1-6)$ \\
Mean pre-operative I-PSS & $8.5(0-18)$ & $8.8(2-18)$ \\
\hline
\end{tabular}

The baseline characteristics are shown in Table 3.1. In the group of patients with clinical BPH/BPE, the mean I-PSS was 8.8 (2-18) (Figure 3.1). None of the patients had severe LUTS (I-PSS > 19), 43 patients $(58.1 \%)$ had moderate LUTS (I-PSS 8-19) and 31 patients (41.9\%) had mild LUTS (I-PSS $\leq 7$ ) (Figure 3.2). I-PSS and PSA levels were negatively correlated $(r=-0.3782, P<0.001)$. The number of biopsies in patients with mild and moderate LUTS is shown in Table 3.2. Patients with mild LUTS underwent more biopsies than patients with moderate LUTS $(P=0.012)$ because there was more uncertainty about the cause of the elevated PSA in these patients.

Table 3.2: Number of biopsies in patients with mild and moderate I-PSS.

\begin{tabular}{lccc}
\hline \multirow{2}{*}{$\begin{array}{l}\text { Number of } \\
\text { biopsies }\end{array}$} & All patients (N = 82) & \multicolumn{2}{c}{ Preoperative I-PSS } \\
\cline { 3 - 4 } & & Mild (<7) (N = 36) & Moderate (8-18) (N = 46) \\
\hline 1 & $49(59.8 \%)$ & $13(36.1 \%)$ & $36(78.3 \%)$ \\
2 & $18(22 \%)$ & $14(38.9 \%)$ & $4(8.7 \%)$ \\
3 & $12(14.6 \%)$ & $7(19.4 \%)$ & $5(10.9 \%)$ \\
$\geq 4$ & $3(3.7 \%)$ & $2(5.6 \%)$ & $1(2.2 \%)$ \\
\hline Number of & BPH/BPE patients & \multicolumn{2}{c}{ Preoperative I-PSS } \\
biopsies & $(\mathbf{N}=\mathbf{7 4})$ & Mild (< 7) (N = 31) & Moderate (8-18) (N = 43) \\
\hline 1 & $45(60.8 \%)$ & $12(38.7 \%)$ & $33(76.7 \%)$ \\
2 & $15(20.3 \%)$ & $11(35.5 \%)$ & $4(9.3 \%)$ \\
3 & $12(16.2 \%)$ & $7(22.6 \%)$ & $5(11.6 \%)$ \\
$\geq 4$ & $2(2.7 \%)$ & $1(3.2 \%)$ & $1(2.3 \%)$ \\
\hline
\end{tabular}




\section{Histology}

After TURP, all resected specimen was weighed and histologically examined. Table 3.3 shows the weight of prostate tissue resected; the mean weight was $43.8 \mathrm{~g}$ in all patients and $44.2 \mathrm{~g}$ in patients with histologically proven $\mathrm{BPH}$. There was a positive correlation between the pre-operative PSA and the weight of tissue resected $(r=0.3199, P<0.0005)$. As shown in table 3.4 , eight out of 82 patients $(9.8 \%)$ had PCa: seven patients $(87.5 \%)$ had clinically important and potentially life threatening PCa (mostly T2 tumours). PCa with a Gleason score $\geq 7$ was labelled as 'clinically important PCa'. Most of these patients had T2/T3 PCa and PCa was usually located anterior or lateral peripheral. All patients with clinically important PCa were treated according to the European Association of Urology (EAU) guidelines (Table 3.4) [2]. One of these patients had a Gleason score of $3+2$, but as this patient was rather young (62 years), very anxious and had $10 \%$ of tumour in the tissue resected, he also received further treatment. One patient with T1aG2 was assigned to watchful waiting because of his age (72 years), his moderate general condition and the acceptable malignant potential of his cancer (Gleason score $3+4=7$ ). The PSA level of this patient dropped from $6.4 \mathrm{ng} / \mathrm{mL}$ before TURP to $0.65 \mathrm{ng} / \mathrm{mL}$ a few months after TURP, which was an extra argument for watchful waiting. There was only $1 \%$ tumour in the prostate tissue resected and we consider a tumour as a T1a tumour when it comprises less than $5 \%$ of the tissue resected, regardless of Gleason score [6]. 
Among those patients with at least two sets of negative biopsies $(N=33)$, four (12.1\%) were diagnosed with PCa in the TURP specimen. Among the patients with only one set of negative biopsies ( $N=45)$, four $(8.9 \%)$ had PCa in the TURP specimen. Only five patients not diagnosed with $\mathrm{PCa}(6.8 \%)$ had signs of inflammation and prostatitis.

Table 3.3: Weight of prostate tissue resected.

\begin{tabular}{lcc}
\hline Weight of prostate tissue & All patients $(\mathbf{N}=\mathbf{8 2})$ & BPH/BPE patients $(\mathbf{N}=\mathbf{7 4})$ \\
\hline$<30 \mathrm{~g}$ & $21(25.6 \%)$ & $19(25.7 \%)$ \\
$30-39 \mathrm{~g}$ & $16(19.5 \%)$ & $14(18.9 \%)$ \\
$40-49 \mathrm{~g}$ & $14(17.1 \%)$ & $13(17.6 \%)$ \\
$50-59 \mathrm{~g}$ & $16(19.5 \%)$ & $15(20.3 \%)$ \\
$\geq 60 \mathrm{~g}$ & $15(18.3 \%)$ & $13(17.6 \%)$ \\
\hline
\end{tabular}


Table 3.4: Histological data of patients diagnosed as having PCa after TURP. ERT: external beam radiotherapy, HPIN: high-grade intraepithelial neoplasia, RRP: radical retropubic prostatectomy.

\begin{tabular}{|c|c|c|c|c|c|c|}
\hline $\begin{array}{l}\begin{array}{l}\text { Age } \\
\text { (years) }\end{array}\end{array}$ & $\begin{array}{l}\text { Pre-op. } \\
\text { PSA } \\
\text { (ng/mL) } \\
\text { PSA ratio }\end{array}$ & $\begin{array}{l}\text { Bioptic } \\
\text { procedures }\end{array}$ & $\begin{array}{l}\text { TURP } \\
\text { histological } \\
\text { examination }\end{array}$ & $\begin{array}{l}\text { RRP } \\
\text { histological } \\
\text { examination }\end{array}$ & $\begin{array}{l}\text { Other } \\
\text { treatment }\end{array}$ & Follow-up \\
\hline 52 & $\begin{array}{l}7.3 \\
(7 \%)\end{array}$ & 2 & $\begin{array}{l}13 \mathrm{~g} / 2 \mathrm{~g} \\
\text { tumour } \\
\text { Gleason } 3+4=7 \\
\text { Peripheral zone } \\
\text { Perineural } \\
\text { invasion }\end{array}$ & $\begin{array}{l}16 \mathrm{~g} / 1.88 \mathrm{~g} \\
\text { tumour } \\
\text { Gleason } 3+4=7 \\
\text { Peripheral zone } \\
\text { Perineural invasion } \\
\text { Mainly anterior } \\
\text { Massive HPIN } \\
\text { T2cG3 }\end{array}$ & - & $\begin{array}{l}\text { No recurrence } \\
\text { after } 1 \mathrm{yr}\end{array}$ \\
\hline 65 & $\begin{array}{l}5.9 \\
(29 \%)\end{array}$ & 1 & $\begin{array}{l}62 \mathrm{~g} / 0.62 \mathrm{~g} \\
\text { tumour } \\
\text { Gleason } 4+4=8 \\
\text { Peripheral zone } \\
\text { No perineural } \\
\text { invasion }\end{array}$ & $\begin{array}{l}8 \mathrm{~g} / 0.16 \mathrm{~g} \text { tumour } \\
\text { Gleason } 4+3=7 \\
\text { Peripheral zone } \\
\text { Perineural invasion } \\
\text { Central } \\
\text { HPIN loci } \\
\text { T2aG3 }\end{array}$ & - & $\begin{array}{l}\text { No recurrence } \\
\text { after } 1 \mathrm{yr}\end{array}$ \\
\hline 66 & $9.5(6.2 \%)$ & 2 & $\begin{array}{l}24 \mathrm{~g} / 1.2 \mathrm{~g} \\
\text { tumour } \\
\text { Gleason } 4+4=8 \\
\text { Peripheral zone } \\
\text { Perineural } \\
\text { invasion }\end{array}$ & $\begin{array}{l}16 \mathrm{~g} / 4.42 \mathrm{~g} \\
\text { tumour } \\
\text { Gleason } 4+3=7 \\
\text { Peripheral zone } \\
\text { Perineural invasion } \\
\text { Central } \\
\text { Limited HPIN foci } \\
\text { T3G2 }\end{array}$ & - & $\begin{array}{l}\text { No recurrence } \\
\text { after } 1 \mathrm{yr}\end{array}$ \\
\hline 62 & $\begin{array}{l}7.2 \\
(11 \%)\end{array}$ & 2 & $\begin{array}{l}31 \mathrm{~g} / 3.1 \mathrm{~g} \\
\text { tumour } \\
\text { Gleason } 3+2=5 \\
\text { Transition zone } \\
\text { No perineural } \\
\text { invasion }\end{array}$ & $\begin{array}{l}15 \mathrm{~g} / 1.5 \mathrm{~g} \text { tumour } \\
\text { Gleason } 3+2=5 \\
\text { Transition zone } \\
\text { Perineural invasion } \\
\text { Central } \\
\text { Limited HPIN foci } \\
\text { T1bG2 }\end{array}$ & - & $\begin{array}{l}\text { No recurrence } \\
\text { after } 2 \text { yrs }\end{array}$ \\
\hline 78 & $\begin{array}{l}13.6 \\
-\end{array}$ & 6 & $\begin{array}{l}37 \mathrm{~g} / 1.85 \mathrm{~g} \\
\text { tumour } \\
\text { Gleason } 4+5=9 \\
\text { Peripheral zone } \\
\text { Perineural } \\
\text { invasion }\end{array}$ & $\begin{array}{l}16 g / 0.84 \text { g tumour } \\
\text { Gleason } 4+5=9 \\
\text { Peripheral zone } \\
\text { Perineural invasion } \\
\text { Central+peripheral } \\
\text { Limited HPIN foci } \\
\text { T2cG3 }\end{array}$ & - & $\begin{array}{l}\text { No recurrence } \\
\text { after } 2 \text { yrs }\end{array}$ \\
\hline 68 & $5.6(8.6 \%)$ & 1 & $\begin{array}{l}16 \mathrm{~g} / 3.2 \mathrm{~g} \\
\text { tumour } \\
\text { Gleason } 3+4=7 \\
\text { Peripheral zone } \\
\text { No perineural } \\
\text { invasion }\end{array}$ & $\begin{array}{l}15 \mathrm{~g} / 0.87 \mathrm{~g} \\
\text { tumour } \\
\text { Gleason } 3+4=7 \\
\text { Peripheral zone } \\
\text { Perineural invasion } \\
\text { Central+anterior } \\
\text { Limited HPIN foci } \\
\text { T2aG3 }\end{array}$ & - & $\begin{array}{l}\text { No recurrence } \\
\text { after } 3 \text { yrs }\end{array}$ \\
\hline 72 & $\begin{array}{l}6.4 \\
(19 \%)\end{array}$ & 1 & $\begin{array}{l}56 \mathrm{~g} / 0.6 \mathrm{~g} \\
\text { tumour } \\
\text { Gleason } 3+4=7 \\
\text { Peripheral zone } \\
\text { No perineural } \\
\text { invasion } \\
\text { T1aG2 }\end{array}$ & - & $\begin{array}{l}\text { Watchful } \\
\text { waiting }\end{array}$ & $\begin{array}{l}\text { No recurrence } \\
\text { after } 1 \mathrm{yr}\end{array}$ \\
\hline 70 & $15.8(29 \%)$ & 1 & $\begin{array}{l}62 \mathrm{~g} / 0.6 \mathrm{~g} \\
\text { tumour } \\
\text { Gleason } 3+3=6 \\
\text { Transition zone } \\
\text { No perineural } \\
\text { invasion }\end{array}$ & - & $\begin{array}{l}\text { ERT } \\
\text { LHRH }\end{array}$ & $\begin{array}{l}\text { No recurrence } \\
\text { after } 2.5 \mathrm{yr}\end{array}$ \\
\hline
\end{tabular}




\section{I-PSS and PSA after TURP}

The I-PSS returned to normal during the first year after TURP in all patients (Figure 3.1). The mean decrease in I-PSS was $7.3(-16$ to -1$)$ (Sign test, $P<$ $0.001)$, resulting in a mean post-operative I-PSS of 1.5 (0-7). The decrease in IPSS appeared to be more pronounced in patients with moderate LUTS: the mean I-PSS decreased with 3.5 points $(-7$ to -1$)$ in patients with mild LUTS, and with 10 points (-16 to -4$)$ in patients with moderate LUTS (Mann-Whitney $U$ test $P<0.001$ ). After TURP, all patients had mild LUTS (Figure 3.2). There was a negative correlation between I-PSS reduction and age $(r=-0.1997 P=0.044)$.

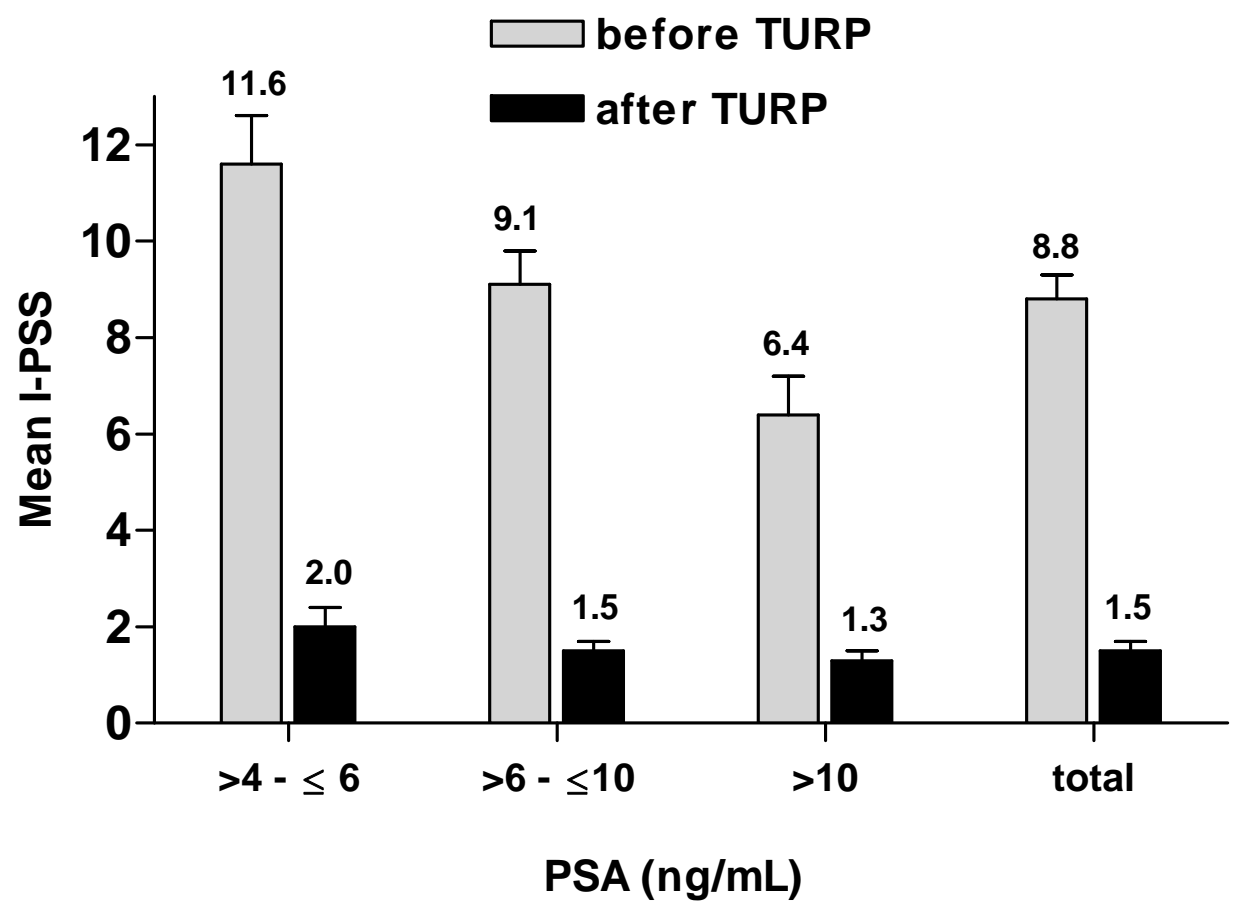

Figure 3.1: Mean I-PSS (SE) within different PSA categories and in the total population of clinical BPH/BPE patients at baseline and after TURP. 


\section{$\square$ mild LUTS \\ moderate LUTS}

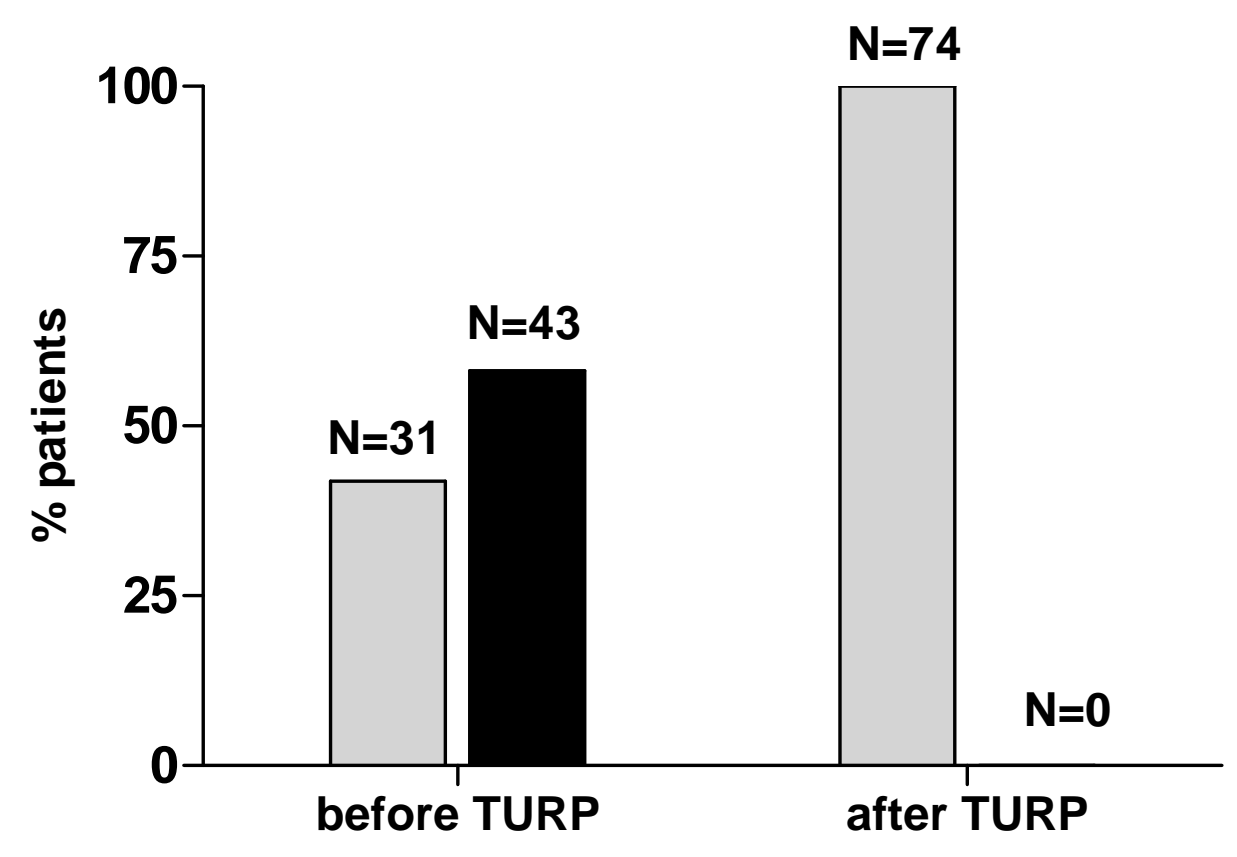

Figure 3.2: Percentage of clinical BPH/BPE patients with mild (I-PSS $\leq 7$ ) or moderate (I-PSS 8-18) LUTS at baseline and after TURP.

In $72 \mathrm{BPH} / \mathrm{BPE}$ patients, PSA levels were re-evaluated in the first year after TURP; two patients had their first check of PSA levels after two years. The mean PSA decreased from $8.8 \mathrm{ng} / \mathrm{mL}$ at baseline to $1.1 \mathrm{ng} / \mathrm{mL} 1$ year after TURP (Table 3.5). Evaluation of the evolution of PSA levels in the first year after TURP showed a normalisation (i.e. PSA $<4 \mathrm{ng} / \mathrm{mL}$ ) in all but one patients $(98.6 \%$ ); $62.5 \%$ even had a post-operative PSA level $\leq 1 \mathrm{ng} / \mathrm{mL}$. In patients where the pre-operative PSA level was $>10 \mathrm{ng} / \mathrm{mL}$, PSA decreased to $\leq 1 \mathrm{ng} / \mathrm{mL}$ in $68.2 \%$ of the patients after TURP $(P<0.001)$. Evaluation of PSA levels in the second year after TURP $(N=50)$, showed that the mean PSA level had decreased to 1.3 ng/mL (0.0-4.9; Table 3.5); 26 patients (52\%) had a PSA level $\leq 1 \mathrm{ng} / \mathrm{mL}$. In 6/12 
patients (50\%) with a pre-operative PSA level $>10 \mathrm{ng} / \mathrm{mL}$, PSA decreased to $\leq 1$ $\mathrm{ng} / \mathrm{mL}$. PSA levels were significantly more reduced in patients with a mild I-PSS than in patients with a moderate I-PSS (Mann-Whitney U Test $P<0.001$ ). There was no statistically significant difference between PSA levels in the first and the second year after TURP.

Table 3.5: Mean PSA at baseline and one and two years after TURP.

\begin{tabular}{|c|c|c|c|c|c|c|c|}
\hline & \multicolumn{6}{|c|}{ Number of patients with PSA } & \multirow{2}{*}{$\begin{array}{c}\text { Mean } \\
\text { PSA }\end{array}$} \\
\hline & $\leq 1$ & $>1 \leq 2$ & $>2 \leq 4$ & $>4 \leq 6$ & $>6 \leq 10$ & $>10$ & \\
\hline Before TURP & 0 & 0 & 0 & 15 & 37 & 22 & 8.8 \\
\hline$(N=74)$ & $(0 \%)$ & $(0 \%)$ & $(0 \%)$ & $(20.3 \%)$ & $(50.0 \%)$ & $(29.7 \%)$ & (SE 0.4) \\
\hline 1 year after TURP & 45 & 15 & 11 & 1 & 0 & 0 & 1.1 \\
\hline$(N=72)$ & $(62.5 \%)$ & $(20.8 \%)$ & $(15.3 \%)$ & $(1.5 \%)$ & $(0 \%)$ & $(0 \%)$ & (SE 0.1) \\
\hline$\geq 2$ years after & 26 & 13 & 9 & 2 & 0 & 0 & 1.3 \\
\hline TURP ( $N=50)$ & $(52.0 \%)$ & $(26.0 \%)$ & $(18.0 \%)$ & $(4.0 \%)$ & (0\%) & (0\%) & (SE 0.2) \\
\hline
\end{tabular}

\section{Discussion}

Patients with an elevated PSA, minor LUTS and no signs of PCa after DRE, TRUS and (multiple) extended multisite biopsies are a challenging problem in urological practice. Thus far, many techniques to improve bioptic yield and reduce the risk of false-negative results have been developed and discussed. Special attention was advised for biopsies in the transition zone of the prostate [3][8][9]. When the first set of biopsies does not show signs of malignancy, a new set can be analysed. However, there are indications that extended multisite biopsies are not harmless and might cause discomfort to the patient [10].

We noticed that in patients with minor complaints of LUTS and no obvious signs of malignancy, elevated PSA levels reflect an increased risk of BOO. There was a negative correlation between the pre-operative PSA and I-PSS in these 
patients. Most likely, this is due to the fact that a high PSA level is caused by a high Pdet $_{\max }$, which gives a good flow and subsequently minor complaints. In agreement with this theory, Abrams et al. previously showed that a normal maximum flow rate does not rule out obstruction [11]. In addition, Laguna et al. suggested that although the I-PSS is useful to evaluate symptom worsening or improvement over time, there is only a poor correlation between the I-PSS and obstruction [12]. Therefore, relative changes in the I-PSS over time may be more meaningful than the absolute I-PPS. This might also explain why all patients included in the present study were obstructed, but none of them had severe LUTS.

Since untreated BOO can cause significant morbidity such as detrusor fatigue [7][13], the patients were treated with TURP. An elevated PSA level is also associated with an increased risk of acute urinary retention and invasive therapy in patients with clinical BPH/BPE [14][15][16][17]. In a recently published systematic review it was shown that TURP is very effective and durable in alleviating LUTS suggestive of BPH [18]. The authors emphasised that from an economic point of view, TURP is a very good treatment option given its long-term efficacy. In addition, TURP seems to be associated with a rather low complication rate [19]. TURP had significant diagnostic and symptomatic benefits for the patients included in our study. After TURP, the I-PSS normalised in all patients, including those with a mild I-PSS. Correlation analysis showed a more pronounced decrease of I-PSS in younger patients; this may be because the detrusor muscle has a bigger potential to recover in this population. Furthermore, all BPH/BPE patients had a sound post-operative decrease of PSA levels within the first year after TURP; in most cases PSA level even fell to $\leq 1 \mathrm{ng} / \mathrm{mL}$. These findings clearly indicate that BOO was the major 
cause of the elevated PSA level in these patients and that de-obstruction is sufficient to normalise PSA. PSA levels did not change significantly between the first and the second year after TURP, providing further evidence for the nonmalignant nature of the disorder. Finally, there was a more pronounced decrease in PSA levels in the patient group with a mild I-PSS. This is most likely due to the negative correlation between pre-operative PSA and I-PSS.

Up till now, there has been controversy about the role of a diagnostic TURP [20][21][22][23][24][25][26] and the importance of PCa arising in the transition zone of the prostate [27][28][29][30]. In the current study, histological analysis of the resected specimen after TURP showed the presence of PCa in eight out of 82 patients (9.8\%); seven of these patients had an important life-threatening type of PCa. In all cases, the tumours were located in the lateral or anterior peripheral zones or in the central zone of the prostate, which are not easily accessible for extended multisite biopsies. All these patients received further treatment. Only one patient was assigned to watchful waiting given his age (72 years), the acceptable malignant potential of his cancer and his moderate general condition. None of the patients recurred within one year. These results indicate that TURP can be an important diagnostic tool in patients with no or minor LUTS, elevated PSA levels and no signs of clinical PCa; special attention should be given to the lateral and anterior part of the prostate away from the rectum during a diagnostic TURP. The number of patients diagnosed with PCa in the TURP specimen was comparable in patients with at least two sets of negative biopsies (12.1\%) and those with only one set of negative biopsies (8.9\%). Although these data concern only a small group of patients, they suggest that performing more than one biopsy does not seem to have considerable diagnostic benefits. However, we believe that in patients with 
mild LUTS, a second biopsy can be performed, as there is more uncertainty about the cause of the elevated PSA in these patients.

Histological analysis also showed that only 5 of the 74 patients with no histological signs of malignancy had signs of inflammation and prostatitis, indicating that inflammation is not the main cause of increased PSA levels in this patient group.

\section{Conclusions}

Our study shows that BOO may account for an elevated PSA level in patients with minor LUTS, no signs of malignancy after (multiple) negative multisite biopsies and diagnosed with bladder outlet obstruction (BOO) secondary to clinical BPH/BPE. TURP can be a proper treatment for these patients as it will result in a clear symptomatic benefit and a (super)normalisation of the PSA level. Furthermore, histological examination of resected specimen is a useful diagnostic tool to distinguish between clinical BPH/BPE and biologically important and potentially life threatening PCa that would normally be overlooked by extended multi-site biopsies. However, a prospective trial is warranted to assess the impact of these results on clinical practice.

\section{Acknowledgements}

The authors are grateful to Ismar Healthcare NV for their assistance in editing of the manuscript. 


\section{References}

[1] Partin AW, Oesterling JE. The clinical usefulness of prostate specific antigen: update 1994. J Urol 1994;152: 1358-68.

[2] Aus G, Abbou CC, Bolla M, Heidenreich A, Schmid HP, van Poppel H et al. EAU guidelines on prostate cancer. Eur Urol 2005;48: 546-51.

[3] Durkan GC, Sheikh N, Johnson P, Hildreth AJ, Greene DR. Improving prostate cancer detection with an extended-core transrectal ultrasonography-guided prostate biopsy protocol. BJU Int 2002;89: 33-9.

[4] Boccon-Gibod L, van der Kwast TH, Montironi R, Boccon-Gibod L, Bono A. Handling and pathology reporting of prostate biopsies. Eur Urol 2004;46: 177-81.

[5] Rosai J. Ackerman's surgical pathology. ed. 9, Mosby Year Book. St. Louis; 2004

[6] Eble J.N, Sauter G., Epstein J.I., Sesterhenn I.A. WHO blue book: World Health Organization Classification of Tumors. Pathology and Genetics of Tumours of the Urinary System and Male Genital Organs. Lyon: IARC Press; 2004

[7] Kirby RS. The clinical assessment of benign prostatic hyperplasia. Cancer 1992;70: 28490.

[8] Fleshner NE, Fair WR. Indications for transition zone biopsy in the detection of prostatic carcinoma. J Urol 1997;157: 556-8.

[9] Djavan B, Ravery V, Zlotta A, Dobronski P, Dobrovits M, Fakhari M et al. Prospective evaluation of prostate cancer detected on biopsies 1, 2, 3 and 4: when should we stop? J Urol 2001;166: 1679-83.

[10] Raaijmakers R, Kirkels WJ, Roobol MJ, Wildhagen MF, Schröder FH. Complication rates and risk factors of 5802 transrectal ultrasound-guided sextant biopsies of the prostate within a population-based screening program. Urology 2002;60: 826-30.

[11] Abrams P, Blaivas J, Griffiths DJ, Nordling J, Koyanagi T, Neal D, et al. The objective evaluation of bladder outflow obstruction. In: Cockett ATK, Khoury S, Aso Y, Chatelain C, Denis L, Griffiths K, Murphy G, eds. Proceedings of the 2nd international consultation on benign prostatic hyperplasia. Jersey: Jersey Scientific Communication, 1993:153-209.

[12] Laguna P, Alivizatos G. Prostate specific antigen and benign prostatic hyperplasia. Curr Opin Urol 2000;10:3-8 
[13] Claridge M, Shuttleworth KE. The dynamics of obstructed micturition. Invest Urol 1964;25: 188-99.

[14] Mochtar CA, Kiemeney LA, Laguna MP, van Riemsdijk MM, Barnett GS, Debruyne FM et al. Prognostic role of prostate-specific antigen and prostate volume for the risk of invasive therapy in patients with benign prostatic hyperplasia initially managed with alpha1-blockers and watchful waiting. Urology 2005;65: 300-5.

[15] Laniado ME, Ockrim JL, Marronaro A, Tubaro A, Carter SS. Serum prostate-specific antigen to predict the presence of bladder outlet obstruction in men with urinary symptoms. BJU Int 2004;94: 1283-6.

[16] Roehrborn CG, McConnell J, Bonilla J, Rosenblatt S, Hudson PB, Malek GH et al. Serum prostate specific antigen is a strong predictor of future prostate growth in men with benign prostatic hyperplasia. PROSCAR long-term efficacy and safety study. J Urol 2000;163: 13-20.

[17] Marberger MJ, Andersen JT, Nickel JC, Malice MP, Gabriel M, Pappas F et al. Prostate volume and serum prostate-specific antigen as predictors of acute urinary retention. Combined experience from three large multinational placebo-controlled trials. Eur Urol 2000;38: 563-8.

[18] Reich O, Gratzke C, Stief CG. Techniques and long-term results of surgical procedures for BPH. Eur Urol 2006;49: 970-8

[19] Muntener M, Aellig S, Kuttel R, Gehrlach C, Hauri D, Strebel RT. Peri-operative morbidity and changes in symptom scores after transurethral prostatectomy in Switzerland: results of an independent assessment of outcome. BJU Int 2006;98: 381-3

[20] Bratt O. The difficult case in prostate cancer diagnosis--when is a "diagnostic TURP" indicated? Eur Urol 2006;49: 769-71.

[21] Puppo P, Introini C, Calvi P, Naselli A. Role of transurethral resection of the prostate and biopsy of the peripheral zone in the same session after repeated negative biopsies in the diagnosis of prostate cancer. Eur Urol 2006;49: 873-8.

[22] Zigeuner R, Schips L, Lipsky K, Auprich M, Salfellner M, Rehak P et al. Detection of prostate cancer by TURP or open surgery in patients with previously negative transrectal prostate biopsies. Urology 2003;62: 883-7. 
[23] Radhakrishnan S, Dorkin TJ, Sheikh N, Greene DR. Role of transition zone sampling by TURP in patients with raised PSA and multiple negative transrectal ultrasound-guided prostatic biopsies. Prostate Cancer Prostatic Dis 2004;7: 338-42.

[24] Kitamura H, Masumori N, Tanuma Y, Yanase M, Itoh N, Takahashi A et al. Does transurethral resection of the prostate facilitate detection of clinically significant prostate cancer that is missed with systematic sextant and transition zone biopsies? Int J Urol 2002;9: 95-9.

[25] Philip J, Dutta RS, Scally J, Foster CS, Javle P. Importance of TURP in diagnosing prostate cancer in men with multiple negative biopsies. Prostate 2005;64: 200-2.

[26] Rovner ES, Schanne FJ, Malkowicz SB, Wein AJ. Transurethral biopsy of the prostate for persistently elevated or increasing prostate specific antigen following multiple negative transrectal biopsies. J Urol 1997;158: 138-41.

[27] Shannon BA, McNeal JE, Cohen RJ. Transition zone carcinoma of the prostate gland: a common indolent tumour type that occasionally manifests aggressive behaviour. Pathology 2003;35: 467-71.

[28] Greene DR, Wheeler TM, Egawa S, Dunn JK, Scardino PT. A comparison of the morphological features of cancer arising in the transition zone and in the peripheral zone of the prostate. J Urol 1991;146: 1069-76.

[29] Reissigl A, Pointner J, Strasser H, Ennemoser O, Klocker H, Bartsch G. Frequency and clinical significance of transition zone cancer in prostate cancer screening. Prostate 1997;30: 130-5.

[30] Merrill RM, Wiggins CL. Incidental detection of population-based prostate cancer incidence rates through transurethral resection of the prostate. Urol Oncol 2002;7: 213-9. 
Chapter 4- Long-term clinical outcome of a diagnostic transurethral resection of the prostate in patients with an elevated prostatespecific antigen level and minor lower urinary tract symptoms

van Renterghem K, Van Koeveringe G, Achten R, van Kerrebroeck P. Urologia Internationalis, accepted for publication. 


\section{Abstract}

Introduction: In patients with minor lower urinary tract symptoms (LUTS), elevated prostate-specific antigen (PSA) levels and (multiple) negative multisite biopsies, therapy decision is complex. Long-term outcome of a diagnostic transurethral resection of the prostate (TURP) in these patients needs to be determined.

Methods: We retrospectively evaluated patients with minor LUTS, elevated PSA levels ( $\geq 4 \mathrm{ng} / \mathrm{mL}$ ) and no signs of prostate cancer. Patients with bladder outlet obstruction (BOO) underwent TURP. When TURP showed no malignancy, patients were yearly evaluated by PSA testing and the International Prostate Symptom Score (IPSS).

Results: The study included 82 consecutive patients satisfying the inclusion criteria. All patients underwent TURP. No malignancy was encountered in 74 patients (90.2\%). Of this group, 36 patients were followed more than 3 years (mean of 62.1 months). One patient (2.8\%) showed a persistently rising PSA level with positive extended multi-site biopsies 4 years after TURP, implying further treatment. Thirty-five patients (97.2\%) had a permanent complete normalisation of PSA levels ( $<4 \mathrm{ng} / \mathrm{mL}$ ) together with normalised IPSS.

Conclusions: We consider an elevated PSA level in patients with minor LUTS and (multiple) negative multi-site biopsies as a sign of BOO. If these patients receive a diagnostic TURP, long-term outcome is excellent.

Keywords: diagnosis; lower urinary tract symptoms; prostate cancer; prostatespecific antigen; transurethral resection of the prostate 


\section{Introduction}

Patients with elevated and/or rising prostate-specific antigen (PSA) levels, minor lower urinary tract symptoms (LUTS) and diagnosed as having clinical benign prostatic enlargement (BPE) and/or benign prostatic hyperplasia (BPH) because of (multiple) negative multi-site biopsies are a challenging problem, especially given the fact that PSA is organ- and not cancer-specific. Many of these patients undergo repeated multi-site biopsies and are often empirically treated with antibiotics, vitamins or nutritional supplements, etc. [1,2] not always with a sound theoretical base for this treatment.

When PSA levels remain elevated and/or rise, uncertainty grows with repeated negative multi-site prostate biopsies. We have shown that in those patients, bladder outlet obstruction ( $\mathrm{BOO}$ ) can be the reason for elevated and/or rising PSA levels [3]. We also demonstrated that after performing a diagnostic transurethral resection of the prostate (TURP), BPH is encountered in most of these patients (90.2\%) [4].

In the present study, we evaluated the long-term outcome of those patients who underwent a diagnostic TURP, more particularly the effect on PSA levels and symptomatic benefit.

\section{Methods}

The study was approved by the Virga Jesse Ziekenhuis (Hasselt) hospital's Ethics Committee and conducted according to the established good clinical practice and the applicable laws and regulation (approval number 06.06/uro06.01). 


\section{Study design}

Patients were evaluated by the main investigator after referral by their general practitioner because of "asymptomatic" elevated and/or rising PSA levels $(\geq 4$ $\mathrm{ng} / \mathrm{mL}$ ). After exclusion of suspicion for prostate cancer (PCa) by digital rectal examination (DRE) and transrectal ultrasound (TRUS), all patients underwent extended (multiple) multi-site prostate biopsies to exclude T1c PCa. Patients with (multiple) negative biopsies were subjected to a urodynamic pressureflow study. When detrusor pressure at maximum flow $\left(P_{\text {det }} Q_{\max }\right)$ was $\geq 40 \mathrm{~cm}$ $\mathrm{H}_{2} \mathrm{O}$ or $20-40 \mathrm{~cm} \mathrm{H} \mathrm{H}_{2} \mathrm{O}$, patients were considered to have $\mathrm{BOO}$ or equivocal detrusor pressures, respectively, and underwent TURP. When TURP showed no malignancy, they were evaluated each year by means of the International Prostate Symptom Score (IPSS) and PSA testing. Initial PSA testing was performed in different laboratories because of referral by their general practitioner. Additional tests, including DRE, TRUS, assessment of the patient's history and extended multi-site prostate biopsies were all conducted by the main investigator. Urodynamic pressure flowmetry was performed by an experienced study nurse.

\section{Study population}

In this study, we retrospectively included all patients with minor LUTS [minor LUTS was defined as mild (IPSS $=0-7$ ) or moderate (IPSS $=8-19$ )], and elevated and/or rising PSA levels, who were referred to our department between 1997 and 2004. These patients had no clinical signs of PCa after DRE, TRUS and extended (multiple) multi-site prostate biopsies. Patients diagnosed as having BOO or equivocal Pdet $_{\max }$ following urodynamic evaluation underwent a diagnostic TURP and were then followed over time. Patients with urinary tract 
infections or clinical suspicion for PCa were excluded from the study. All patients were informed about the potential risks of TURP.

\section{Study procedures}

In all cases, 12-core biopsies were performed with a spring-loaded automatic biopsy gun (Bard magnum) fitted with an 18-gauge Tru-cut needle guided by a side firing transrectal probe US $7.5 \mathrm{mHz}$ bipolar. Briefly, 6 laterally targeted biopsies ( 2 from the transition zone and 4 from the lateral peripheral zones) were taken in addition to conventional parasaggital sextant biopsies at the base, mid-gland and apical regions of the prostate [5]. All patients received quinolone prophylaxis for 5 days, starting the day before the biopsy. No local anaesthesia was used. Prostate biopsies were handled and reported as proposed by the European society of uropathology [6]. Urodynamics were performed using Laborie Medical technologies INC/UDS-64-IIs. All patients received low-dose quinolone prophylaxis for 48 hours, starting the day before the urodynamic study. Filling was done standing with a filling speed of 35 $\mathrm{mL} / \mathrm{min}$, using a 6 French filling catheter (double lumen). Pressure-flow analysis was carried out according to the International Continence Society (ICS) criteria (Abrams-Griffiths score) [7]. Endoscopic procedures were done under locoregional anaesthesia using an Olympus resectoscope 26 or 28 charrière, depending on estimated prostate volume. After TURP, resected prostate fragments were weighed and carefully histologically examined. The fragments were embedded until 4 sets, each containing $2 \mathrm{~g}$ of tissue, were filled. When there was an excess of prostate tissue, 1 additional cassette for each additional $10 \mathrm{~g}$ of tissue was filled [8]. 


\section{Statistical methods}

All statistical analyses were performed using the routines of the Statistical Package for Social Sciences software. When two successive results were compared on the same patients, the paired sample t-test was used for variables for which the normality assumption was accepted; the nonparametric sign test was used for variables with no normal distribution. Two groups of patients were compared using the independent samples t-test. A $P$ value $<0.05$ was considered to indicate statistical significance.

\section{Results}

Number of patients and baseline characteristics

Of the 82 patients satisfying the inclusion criteria of minor LUTS, elevated and/or rising PSA levels ( $\geq 4 \mathrm{ng} / \mathrm{mL}$ ) and no signs of PCa after DRE, TRUS and extended (multiple) multi-site prostate biopsies, 79 patients (96.3\%) were clearly obstructed $\left(\mathrm{PdetQ}_{\max } \geq 40 \mathrm{~cm} \mathrm{H} \mathrm{O}\right.$ ) and 3 patients (3.7\%) had an equivocal $P_{\text {det }} \max \left(20-40 \mathrm{~cm} \mathrm{H} \mathrm{H}_{2} \mathrm{O}\right)$. After TURP, 8 patients (9.8\%) were diagnosed as having PCa; 74 patients (90.2\%) had histologically proven $\mathrm{BPH}$. In this $\mathrm{BPH}$ group, the maximum follow-up period was 8 years and 7 months; 36 patients had a follow-up period of more than 3 years and were evaluated with regard to long-term follow-up; 38 patients had a follow-up period less than 3 years and were therefore not taken into account. Of those 36 patients, 1 patient (2.8\%) had a persistently rising PSA level with positive extended multisite prostate biopsies 4 years after TURP. This patient underwent subsequently a radical retropubic prostatectomy (RRP). Thirty-five patients (97.2\%) were then included in our long-term evaluation and were referred to as the "PCa excluded group". In this "PCa excluded group", TURP specimens showed in 2 
patients $(5.7 \%)$ signs of chronic prostatitis which cannot be considered as the cause of the elevated PSA levels.

Baseline characteristics of all patients correlated well with that of the PCa excluded group (Table 4.1). In this latter group the mean age was 65 years; patients were followed for a mean of 61.5 months and had a mean preoperative PSA level of $8.2 \mathrm{ng} / \mathrm{mL}$. In the majority of patients (80\%), the preoperative PSA level was between $4-10 \mathrm{ng} / \mathrm{mL}$. A suspicious PSA velocity with a mean value of $3.0 \mathrm{ng} / \mathrm{mL} /$ year could be measured in 20 patients; free-to-total PSA was measured in 27 patients with a mean value of 18 . The mean preoperative IPSS value was 9.1. None of the 35 patients had severe LUTS (IPSS > 19); $42.9 \%$ of patients had mild symptoms (IPSS $\leq 7$ ) and $51.1 \%$ of the patients had moderate symptoms (IPSS 8-19). Patients underwent a mean of 1.7 sets (range 1-6) of extended multi-site prostate biopsies. Patients with mild LUTS underwent more biopsies than patients with moderate LUTS $(P=0.012)$ [2]. Upon urodynamic pressure flow studies, 1 patient (2.9\%) had an equivocal Pdet $_{\max }\left(20-40 \mathrm{~cm} \mathrm{H}_{2} \mathrm{O}\right)$ and 34 patients (97.1\%) were clearly obstructed

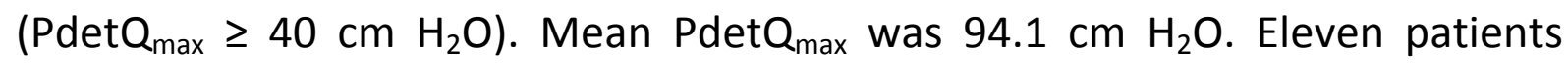
(31.4\%) had a median lobe on cystoscopy. Mean resected weight was $47.4 \mathrm{~g}$. 
Table 4.1. Baseline characteristics.

\begin{tabular}{|c|c|c|c|}
\hline Characteristic & Parameter & All patients $(n=36)$ & $\begin{array}{l}\text { PCa excluded patients } \\
(n=35)\end{array}$ \\
\hline \multirow[t]{2}{*}{ Follow-up (months) } & mean & 62.1 & 61.5 \\
\hline & range & $38-103$ & $38-103$ \\
\hline \multirow[t]{3}{*}{ Age (years) } & mean & 64.8 & 65 \\
\hline & SD & 5.38 & 5.32 \\
\hline & range & $53-73$ & $53-73$ \\
\hline Pre-operative PSA & mean & 8.2 & 8.2 \\
\hline \multirow[t]{2}{*}{ (ng/mL) } & SD & 2.75 & 2.78 \\
\hline & range & $4.2-15.0$ & $4.2-15.0$ \\
\hline \multirow[t]{3}{*}{ PSA density } & mean & 0.21 & 0.21 \\
\hline & SD & 0.09 & 0.08 \\
\hline & range & $0.10-0.40$ & $0.10-0.40$ \\
\hline PSA velocity & mean & 3.0 & 3.0 \\
\hline (ng/mL/year) & SD & 1.82 & 1.82 \\
\hline$(n=20)$ & range & $1.1-7.0$ & $1.1-7.0$ \\
\hline \multirow[t]{3}{*}{ Pre-operative IPSS } & mean & 9.3 & 9.1 \\
\hline & SD & 4.3 & 4.29 \\
\hline & range & $2.0-18.0$ & $2.0-18.0$ \\
\hline \multirow[t]{3}{*}{$P_{\operatorname{det}} Q_{\max }\left(\mathrm{cm} \mathrm{H}_{2} \mathrm{O}\right)$} & mean & 93.5 & 94.1 \\
\hline & SD & 34.6 & 34.88 \\
\hline & range & $25.0-200.0$ & $25.0-200.0$ \\
\hline \multirow[t]{3}{*}{ Resected weight (g) } & mean & 46.8 & 47.4 \\
\hline & SD & 18.8 & 18.61 \\
\hline & range & $15.0-100.0$ & $15.0-100.0$ \\
\hline
\end{tabular}

Evolution of IPSS and PSA level after TURP

In the PCa excluded group of patients, the mean PSA level was $0.9 \mathrm{ng} / \mathrm{mL}$ (range $0.1-2.7 \mathrm{ng} / \mathrm{mL}$ ) 1 year post-TURP and $1.1 \mathrm{ng} / \mathrm{mL}$ (range $0.2-3.9 \mathrm{ng} / \mathrm{mL}$ ) at the end of the follow-up period (Figure 4.1). At the end of the follow-up period, the PSA level decreased to $<1 \mathrm{ng} / \mathrm{mL}$ in 18 patients $(51.5 \%)$ and to $\geq 1 \mathrm{ng} / \mathrm{mL}$ in 17 patients (48.6\%). The mean IPSS value was 1.37 (range 0-3) 1 year postTURP and 1.9 (range $0-8$ ) at the end of the follow-up period (Figure 4.2). 


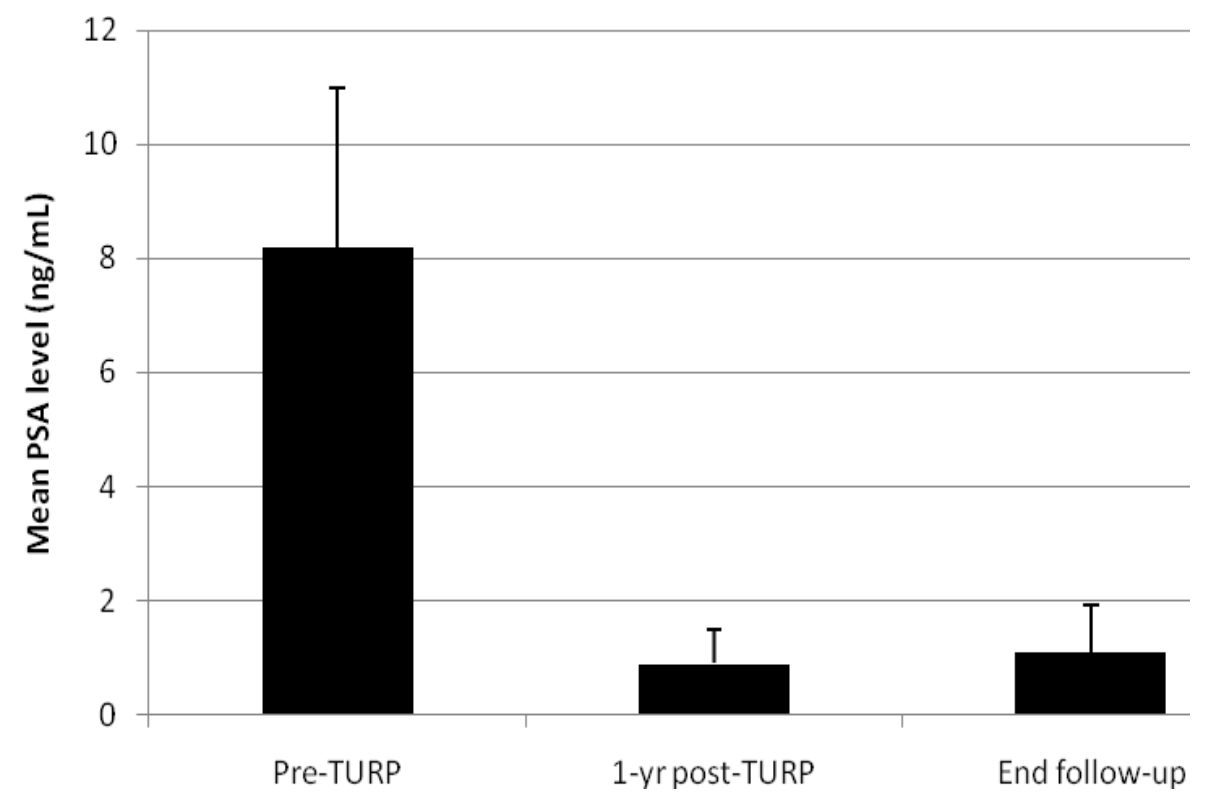

Figure 4.1: Mean prostate-specific antigen (PSA) level $(\mathrm{ng} / \mathrm{mL}$ ) pre-operatively, 1 year after transurethral resection of the prostate (TURP) and at the end of the follow-up period in the prostate cancer excluded group of patients $(n=35)$.

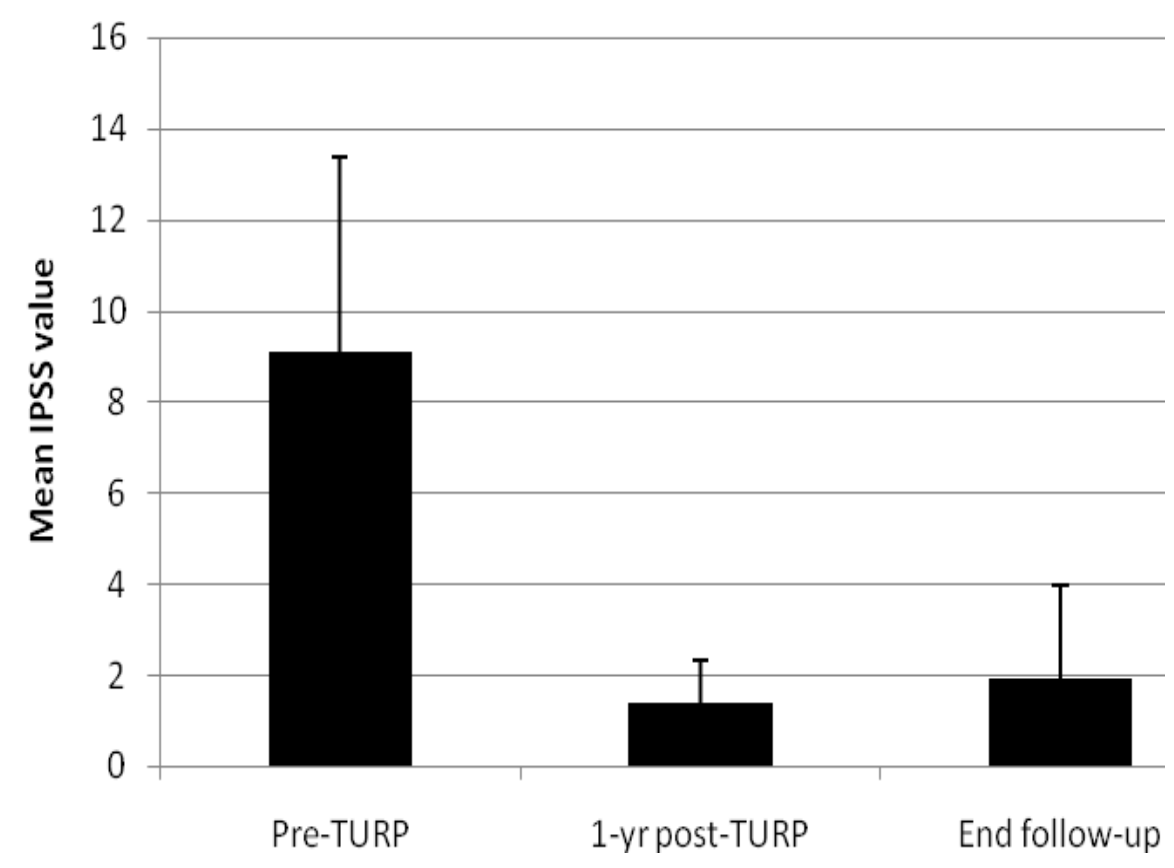

Figure 4.2: Mean International Prostate Symptom Score (IPSS) value preoperatively, 1 year after transurethral resection of the prostate (TURP) and at the end of the follow-up period in the prostate cancer excluded group of patients $(n=35)$. 


\section{Discussion}

When to perform a "diagnostic TURP" is an important urological question. A persistently elevated and/or rising PSA level is a relevant clinical matter because it causes anxiety in the patient and uncertainty for the general practitioner and urologist. This uncertainty grows with repeated elevated and/or rising PSA levels and with (multiple) negative extended multi-site prostate biopsies. In addition, it has been demonstrated that men with abnormal PCa screening tests report an increased cancer-related worry and more problems with sexual function [9]. In order to solve this problem, most urologists (repeatedly) perform extended multi-site biopsies.

Different biopsy strategies have been developed such as age-related cut-off PSA values, the free-to-total PSA ratio or even complexed PSA [10]. Catalona et al. [11] propose to measure PSA density, with a cut-off value of 0.078 , to predict whether a patient has malignant or benign disease. In the present study, we found a mean PSA density of 0.21 (range $0.10-0.40$ ) in the group of all patients as well as in the PCa excluded group. According to Berger et al, a PSA velocity of $>0.98 \mathrm{ng} / \mathrm{mL} /$ year may be a sensitive and specific clinical marker for the development of PCa [12]. Other studies suggest a cut-off value of $0.4 \mathrm{ng} / \mathrm{mL} /$ year for men younger than 60 [13]. In our study, a suspicious PSA velocity ranging between 1.1 and $7.0 \mathrm{ng} / \mathrm{mL} /$ year (with a mean of 3.0 $\mathrm{ng} / \mathrm{mL} /$ year) was measured in 20 patients in both groups, but the subsequent biopsies were negative. This implies that, in addition to the PSA levels [3], the PSA velocity can be a parameter for BOO. All together, when the PSA level is elevated or rising, and/or the PSA density is elevated and/or the PSA velocity is pathological, negative extended (multi-site) biopsies suggest the presence of BOO. In this perspective, Djavan et al. [14] demonstrated that the PCa 
detection rate after a first and a second biopsy set is dramatically low (about $5 \%)$, so in general, it is not recommended to perform more than 2 biopsy sets to rule out PCa. Deliveliotis and colleagues have shown that biopsies of the transitional zone are valuable, especially in repeated biopsies. The diagnostic yield in first biopsies was low (2.1\%) [15].

Patients diagnosed with BOO can be offered watchful waiting. However, potential side-effects of watchful waiting include detrusor muscle decompensation and development of renal insufficiency [16]. In addition, uncertainty/anxiety will continue since PSA levels will not decrease. The EAU guidelines state that BPH can be considered a progressive disease [17]. Moreover, a group of patients at increased risk of progression can be identified based on specific risk factors, i.e. age, PSA level and prostate volume. It might be appropriate to identify these patients at risk of progression and initiate early preventative treatment. Furthermore, it has been shown that an elevated and/or rising PSA level is associated with an increased risk for acute urinary retention, BPH-related invasive surgery and $\mathrm{BOO}$ in symptomatic patients [18]. Because PSA is a strong predictor of prostate growth in men with BPH, it may be an important factor when considering treatment options [19]. Medical treatment has also no influence on the PSA levels [20], except for $5 \alpha$-reductase inhibitors such as finasteride and dutasteride, where the PSA response is heterogeneous which makes monitoring of these patients difficult [21]. Other disadvantages of medical treatment are that histological examination is not possible and lack of cure implies life-long treatment emphasising the need for a thorough understanding of the long-term outcome [22]. Moreover, the costs of long-term medical treatment should be taken into account [23][24]. 
We believe that for the above mentioned reasons, patients with a persistently elevated PSA and/or rising PSA which is indicative of BOO should be offered TURP [4]. Until now, there has been controversy about the value of a diagnostic TURP. Zigeuner et al [25] found that the PCa detection rate by TURP or open prostatectomy in patients with obstructive symptoms and previously negative transrectal prostate biopsies was $7.9 \%$. They proposed using TURP as a diagnostic tool after a negative biopsy in patients with voiding symptoms and a suspicious DRE. The diagnostic yield in asymptomatic men, however, is still unknown. Additionally, Ozden et al [26] have performed a study which included 64 patients with LUTS, normal DRE, elevated PSA and negative EPB and negative histology in TURP/open prostatectomy. After 6 months 32 patients were re-evaluated with PSA and EPB; 7 out 32 patients still suffered from elevated PSA levels and 1 out of 7 patients had PCa, indicating that patients with those characteristics should be followed like BPH patients. However, the long term follow-up of these patients remains unclear. Furthermore, the benefit of transition zone sampling by TURP in patients with rising PSA levels and multiple negative peripheral zone biopsies has been demonstrated [27]. In another study, it was concluded that BOO should not interfere when considering TURP as a treatment option [28]. In our opinion, there are several arguments in favour of treating patients with a persistently elevated PSA and/or rising PSA and BOO with a "diagnostic" TURP. Firstly, BOO is a condition that should be cured since it can cause detrusor decompensation or renal insufficiency [16]. Secondly, a "diagnostic" TURP has the advantage of an extensive histological examination [4]. We previously showed that approximately $10 \%$ of patients with a persistently elevated PSA and/or rising PSA, negative biopsies and $\mathrm{BOO}$ had $\mathrm{PCa}$ in the resected tissue following TURP of whom $87.5 \%$ had a significant PCa mainly located anteriorly and laterally in 
the peripheral zone. The remaining patients $(90 \%)$ were diagnosed with BOO due to BPH/BPE. In the present follow-up study, 1 patient (2.8\%) developed a persistently rising PSA level which resulted in positive extended multi-site prostate biopsies after 4 years. The tumour was located anteriorly and classified as T2cG2. Thirdly, the long-term outcomes regarding the PSA levels and symptomatic benefit are excellent. Pre-operatively, the mean IPSS value was 9.1 while it was 1.9 at the end of the follow-up period. The mean preoperative PSA level of $8.2 \mathrm{ng} / \mathrm{mL}$ dropped to a mean PSA level of $1.1 \mathrm{ng} / \mathrm{mL}$ at the end of follow-up period. After TURP, no statistically significant PSA evolution was found which confirmed the hypothesis that the elevated and/or rising PSA levels are due to BOO. It has been stated that performing a TURP should be the "gold standard" in relieving symptoms of LUTS [20][29]. Our study confirms the excellent long-term outcome with a follow-up period up to 103 months. Finally, another argument in favour of a "diagnostic" TURP is the economic benefit [24]. In a nation-wide long-term analysis of 23,123 cases who underwent TURP or open prostatectomy, the overall incidence of a secondary procedure after primary TURP was $5.8 \%$ at 1 year, $12.3 \%$ at 5 years and $14.7 \%$ within 8 years [30]. In our series, only 1 patient out of $36(2.8 \%)$ needed a reTURP after 3 years.

\section{Conclusions}

Patients with elevated and/or rising PSA levels, minor LUTS and diagnosed as having clinical BPE/BPH because of (multiple) negative multi-site extended prostate biopsies are very likely to have BOO. If urodynamic pressure flow studies confirm BOO, we recommend considering a diagnostic TURP as this relieves obstruction and the resected tissue can be histologically examined for cancerous cells. In most cases $(90.2 \%)$, this will show no signs of malignancy. 
The long-term follow-up of a diagnostic TURP shows excellent results with regard to a permanent (super) normalisation of PSA levels and IPSS values. On the other hand, patients should be monitored yearly by means of PSA (velocity) since we encountered in 1 patient (2.8\%) a potentially life-threatening PCa after 4 years.

\section{Acknowledgements}

The authors wish to thank Dr Sven Deferme and Dr Rita Aert who provided medical writing services on behalf of PharmaXL. 


\section{References}

[1] Kobayashi M, Nukui A, Morita T: Serum PSA and percent free PSA value changes after antibiotic treatment. A diagnostic method in prostate cancer suspects with asymptomatic prostatitis. Urol Int 2008;80:186-192.

[2] Erol H, Beder N, Calişkan T, et al: Can the effect of antibiotherapy and antiInflammatory therapy on serum PSA levels discriminate between benign and malign prostatic pathologies? Urol Int 2006;76:20-26.

[3] van Renterghem K, Van Koeveringe G, Van Kerrebroeck P: Rising PSA in patients with minor LUTS without evidence of prostatic carcinoma: a missing link? Int Urol Nephrol 2007;39:1107-1113.

[4] van Renterghem K, Van Koeveringe G, Achten $R$, et al: Clinical relevance of transurethral resection of the prostate in "asymptomatic" patients with an elevated prostate-specific antigen level. Eur Urol 2007;52:819-826.

[5] Durkan GC, Sheikh N, Johnson P, et al: Improving prostate cancer detection with an extended-core transrectal ultrasonography-guided prostate biopsy protocol. BJU Int 2002;89:33-39.

[6] Boccon-Gibod L, van der Kwast TH, Montironi R, et al: Handling and pathology reporting of prostate biopsies. Eur Urol 2004;46:177-181.

[7] Griffiths D, Hofner K, van Mastrigt R, et al: Standardization of terminology of lower urinary tract function; pressure-flow studies of voiding, urethral resistance, and urethral obstruction. International Continence Society Subcommittee on Standardization of Terminology of Pressure-Flow Studies. Neurourol Urodyn $1997 ; 16: 1-18$

[8] Rosai J: Rosai and Ackerman's surgical pathology. ed. 9, Mosby Year Book. St. Louis, 2004.

[9] Katz D, Jarrard D, McHorney C, et al: Health perceptions in patients who undergo screening and workup for prostate cancer. Urology 2007;69:215-220.

[10] Froehner $M$, Hakenberg OW, Koch R, et al: Comparison of the clinical value of complexed PSA and total PSA in the discrimination between benign prostatic hyperplasia and prostate Cancer. Urol Int 2006;76:27-30. 
[11] Catalona WJ, Southwick PC, Slawin KM, et al. Comparison of percent free PSA, PSA density and age specific PSA cut-offs for prostate cancer detection and staging. Urology $2000 ; 56: 255-260$.

[12] Berger A, Deibl M, Strasak A, et al. Large-Scale Study of Clinical Impact of PSA Velocity: Long-Term PSA Kinetics as Method of Differentiating Men with from Those without Prostate Cancer. Urology 2007;69:134-138.

[13] Loeb S, Roehl KA, Catalona WJ, et al: Prostate specific antigen velocity threshold for predicting prostate cancer in young men. J Urol 2007;177:899-902.

[14] Djavan B, Ravery V, Zlotta A, et al: Prospective evaluation of prostate cancer detected on biopsies 1, 2, 3 and 4: when should we stop? J Urol 2001;166:1679-1683.

[15] Deliveliotis C, Varkarakis J, Albanis S, et al: Biopsies of the transitional zone of the prostate. Should it be done on a routine basis, when and why? Urol Int. 2002;68:113117.

[16] Rule AD, Lieber MM, Jacobsen SJ. Is benign prostatic hyperplasia a risk factor for chronic renal failure? J Urol 2005;173:691-696.

[17] Section 1.2.2 of the EAU guidelines, http://www.uroweb.org/fileadmin/user_upload/ Guidelines/BPH.pdf.

[18] Mochtar CA, Kiemeney LA, Laguna MP, et al: Prognostic role of prostate-specific antigen and prostate volume for the risk of invasive therapy in patients with benign prostatic hyperplasia initially managed with alpha1-blockers and watchful waiting. Urology 2005;65:300-305.

[19] Roehrborn CG, McConnell J, Bonilla J, et al: Serum prostate specific antigen is a strong predictor of future prostate growth in men with benign prostatic hyperplasia. PROSCAR long-term efficacy and safety study. J Urol 2000;163:13-20.

[20] Rassweiler J, Teber D, Kuntz R, et al: Complications of transurethral resection of the prostate (TURP) - incidence, management and prevention. Eur Urol 2006;50:969-979.

[21] Brawer MK, Lin DW, Williford WO, et al: Effect of finasteride and/or terazosin on serum PSA: results of VA Cooperative Study \#359. Prostate 1999;39:234-239.

[22] Madersbacher S, Marszalek M, Lackner J, et al: The long-term outcome of medical therapy for BPH. Eur Urol 2007;51:1522-1533. 
[23] DiSantostefano RL, Biddle AK, Lavelle JP: An evaluation of the economic costs and patient-related consequences of treatments for benign prostatic hyperplasia. BJU Int 2006;97:1007-1016.

[24] Teillac P, Scarpa R: Economic issues in the treatment of BPH. Eur Urol Suppl 2006;5:1018-1024.

[25] Zigeuner R, Schips L, Lipsky K, et al: Detection of prostate cancer by TURP or open surgery in patients with previously negative transrectal prostate biopsies. Urology 2003;62:883-887.

[26] Ozden C, Inal G, Adsan O, et al: Detection of prostate cancer and changes in prostatespecific antigen (PSA) six months after surgery for benign prostatic hyperplasia in patients with elevated PSA. Urol Int. 2003;71:150-153.

[27] Radhakrishnan S, Dorkin TJ, Sheikh N, et al: Role of transition zone sampling by TURP in patients with raised PSA and multiple negative transrectal ultrasound-guided prostatic biopsies. Prostate Cancer Prostatic Dis 2004;7:338-342.

[28] Puppo P, Introini C, Calvi P, et al: Role of transurethral resection of the prostate and biopsy of the peripheral zone in the same session after repeated negative biopsies in the diagnosis of prostate cancer. Eur Urol 2006;49:873-878.

[29] Reich O, Gratzke C, Stief CG: Techniques and long-term results of surgical procedures for BPH. Eur Urol 2006;49:970-978.

[30] Madersbacher S, Lackner J, Brössner C, et al: Reoperation, myocardial infarction and mortality after transurethral and open prostatectomy: a nation-wide, long-term analysis of 23,123 cases. Eur Urol 2005;47:499-504. 
Chapter 5 - Prospective study of the role of transurethral resection of the prostate in patients with an elevated prostate specific antigen level, minor lower urinary tract symptoms and proven bladder outlet obstruction

van Renterghem K, Van Koeveringe G, Achten R, van Kerrebroeck P. Eur Urol. 2008 Dec;54(6):1385-1392. 


\section{Abstract}

Background: Deciding on strategy for patients with minor lower urinary tract symptoms (LUTS), elevated prostate specific antigen (PSA) levels, nonsuspicious digital rectal examination (DRE) and/or transrectal ultrasound (TRUS) and multiple negative extended prostate biopsies is complex.

Objectives: To define the role and clinical significance of transurethral resection of prostate (TURP) in these patients.

Design, Settings and Participants: Thirty-three patients with elevated PSA, minor LUTS, as assessed by the International Prostate Symptoms Score (IPSS), no suspicion for prostate cancer on DRE and/or TRUS and negative extended prostate biopsies were prospectively enrolled in a cohort study at a tertiary care institution.

Intervention: After full urodynamic investigation, showing all patients to be obstructed, TURP was performed.

Measurements: Resected tissue was histologically examined for presence of prostate cancer. Within 6 months after TURP, patients were clinically reevaluated by means of IPSS and PSA.

Results and Limitations: Preoperatively, mean PSA and IPSS values were 8.2 $\mathrm{ng} / \mathrm{ml}$ and 6.8 , respectively. Mean detrusor pressure at maximum flow was $80.3 \mathrm{~cm} \mathrm{H} \mathrm{H}_{2} \mathrm{O}$. Histological examination after TURP revealed benign prostate hyperplasia in $81.8 \%$ (subgroup 1) and aggressive prostate cancer in $6.1 \%$ (subgroup 2). In $12.1 \%$, only a few chips of unaggressive prostate cancer (T1a) were detected. In patients without signs of aggressive prostate cancer $193.9 \%$ $=12.1 \%+81.8 \%$, subgroup 3$)$, mean postoperative PSA and IPSS values were $0.6 \mathrm{ng} / \mathrm{ml}$ and 2.4 , respectively, while these values were $0.6 \mathrm{ng} / \mathrm{ml}$ and $2.5 \mathrm{in}$ subgroup $1(p<0.0001)$. This study is limited in sample size, requiring more conformational research. 
Conclusions: This prospective study shows that in patients with minor LUTS and no suspicion for prostate cancer, bladder outlet obstruction can result in elevated PSA levels. These patients will benefit from TURP regarding symptomatology and (super)normalisation of PSA levels. Moreover, albeit in few cases, histological examination will reveal aggressive prostate cancer.

Keywords: Prostate Cancer; Transurethral resection of prostate; Prostatespecific antigen; Bladder Outlet Obstruction; Lower Urinary Tract Symptoms; Prostate Biopsy. 


\section{Introduction}

Since prostate-specific antigen (PSA) has proven to be a useful tumour marker for the prostate gland, patients with an elevated and/or rising PSA level form a substantial part of a common urological practice. Even if digital rectal examination (DRE) and/or transrectal ultrasound (TRUS) are negative, an extended prostate biopsy can be performed to rule out the presence of prostate cancer [1]. After negative biopsies, patients are subjected to a close surveillance policy, if needed with a treatment without sound theoretical base, such as antibiotics and/or diet supplements. If PSA levels remain elevated or even increase over time, most patients are subjected to a new series of extended prostate biopsies. Although repeating this procedure can be very useful, as demonstrated by Djavan and co-workers [2], these repetitions are very stressful, especially for patients having continuously elevated PSA levels and minor lower urinary tract symptoms (LUTS). For this group of patients, uncertainty will grow. Additionally, the follow-up of these patients is a considerable concern for the general practitioner and the urologist. Results from previous studies show that in this group of patients, bladder outlet obstruction (BOO) can be suspected and eventually proven by full urodynamic investigation [3][4][5]. Therefore, the objective of this study was to define the role and clinical significance of a transurethral resection of prostate (TURP) in these patients.

\section{Materials and Methods}

The study was approved by the Virga Jesse Ziekenhuis (Hasselt) hospital's Ethics Committee and conducted according to the established good clinical practice and the applicable laws and regulation (approval number 06.06/uro06.01). 


\section{Study population and study design}

In this study, a cohort of 33 consecutive patients was evaluated. The time interval for patient accrual was from June 2005 to May 2007. All patients were referred to the principal investigator by their general practitioner as a result of an elevated $(\geq 4 \mathrm{ng} / \mathrm{ml}$ ) and/or rising PSA [PSA velocity (PSAV) $>0.98$ $\mathrm{ng} / \mathrm{ml} /$ year] [6]. The proportion of patients with the characteristics of the present prospective cohort compared to all patients referred to our institution for the early detection of prostate cancer is estimated to be $5 \%$. Patients were not referred to our department because of bothering LUTS; only patients with minor LUTS (IPSS = 0-19) were included in this study. Minor LUTS was defined as mild (IPSS $=0-7)$ or moderate (IPSS $=8-19)$. Only patients without clinical suspicion for prostate cancer on DRE and/or TRUS were considered after at least a minimum of one set of negative extended 12-core prostate biopsies. When T1c prostate cancer was excluded, a full urodynamic evaluation with pressure flowmetry was performed in all 33 patients. Additionally, all patients underwent transurethral resection of the prostate (TURP) since BOO was proven in all cases. All patients were fully informed about all aspects of the TURP procedure. After TURP, prostatic tissue was histologically examined by one referee pathologist. Patients were re-evaluated within six months after TURP with regard to international prostate symptoms score (IPSS) and PSA levels.

\section{Study procedures}

TRUS was performed using a Kretz Ultrasound type combison $310 \mathrm{~A}+$. The 12core biopsies were prepared with a spring-loaded automatic biopsy gun (Bard magnum) fitted with a 18-gauge Tru-cut needle guided by a side firing transrectal probe US $7.5 \mathrm{mHz}$ biplanar. The 12-core biopsy protocol was 
described in 2002 by Durkan et al [7]. Briefly, six laterally targeted biopsies, two from the transition zone and four from the lateral peripheral zones, were taken in addition to the conventional parasagittal sextant biopsies (at the base, mid-gland, and apical regions of the prostate). All biopsies were performed following this protocol. Patients received quinolone prophylaxis for 5 days, starting the day before the biopsy. No local anaesthesia was used. Prostate biopsies were handled and reported as proposed by the European Society of Uropathology [8]. Urodynamics were performed using Laborie Medical technologies INC/UDS-64-IIs. All patients were treated with low-dose quinolone prophylaxis for 48 hours, starting the day before urodynamics. Filling was done standing with a filling speed of $35 \mathrm{ml} / \mathrm{min}$, using a $6 \mathrm{~F}$ filling catheter (double lumen). Pressure flow analysis occurred in agreement with the International Continence Society (ICS) criteria (Abrams-Griffiths score) [9]. Patients with a Pdet $Q_{\max }<20 \mathrm{~cm} \mathrm{H}_{2} \mathrm{O}$ were considered unobstructed, those with a $P$ det $Q_{\max }>40 \mathrm{~cm} \mathrm{H} \mathrm{H}_{2} \mathrm{O}$ were considered obstructed and a $P$ det $Q_{\max }$ between 20 and $40 \mathrm{~cm} \mathrm{H} \mathrm{H}_{2} \mathrm{O}$ was considered equivocal. Endoscopic procedures were done under loco-regional anaesthesia using an Olympus resectoscope 26 or 28 Charrière, depending on estimated prostate volume. After TURP, resected prostate fragments were weighed and carefully examined [10]. Afterwards, the fragments were embedded until 4 sets, each containing $2 \mathrm{~g}$ of tissue, were filled. Each additional $10 \mathrm{~g}$ of prostate tissue was used to fill an extra cassette. The degree of aggressiveness of the prostate cancer was determined taking into account the Gleason value, the amount of cancer cells and the age of the subjects [11][12]. To determine PSAV, PSA measurements were separated by a sufficiently long period of time. PSA density (PSAD) was calculated with ultrasound prostate volume and not with resected weight. 


\section{Statistical analysis}

All statistical analyses were performed using the routines of the Statistical Package for Social Sciences software. When two successive results were compared on the same patients, the two-sided paired sample t-test was used for variables for which the normality assumption was accepted $(p<0.05)$; the nonparametric sign test was used for variables with no normal distribution.

\section{Results}

\section{Baseline characteristics}

In total, 33 patients satisfied the inclusion criteria as described higher and were included in this study. The baseline characteristics for the patients in this study are shown in Table 5.1. The mean age of all patients was 66.6 years. The mean PSA level before TURP was $8.2 \pm 3.0 \mathrm{ng} / \mathrm{ml}$ for all patients. Different subgroups were defined based on the outcome of the histology assessment. Basically, subgroup 1 consists of subjects with benign prostatic hyperplasia (BPH), subgroup 2 consists of subjects with aggressive prostate cancer and subgroup 3 consists of subjects with unagressive prostate cancer and/or BPH. For further details on the definition of the subgroups we refer to the next section (histology). PSA levels were $8.5 \pm 3.1 \mathrm{ng} / \mathrm{ml}$ and $8.2 \pm 3.0 \mathrm{ng} / \mathrm{ml}$, in subgroup 1 and subgroup 3, respectively.

Concerning PSAV, the mean value in all cases was $3.0 \pm 2.5 \mathrm{ng} / \mathrm{ml} /$ year. For subgroup 1 and subgroup 3, this amounted to $3.1 \pm 2.6 \mathrm{ng} / \mathrm{ml} /$ year and $3.0 \pm$ $2.5 \mathrm{ng} / \mathrm{ml} /$ year, respectively. The values for PSA ratio and PSAD are described in Table 5.1. 
Table 5.1. Baseline characteristics of the study participants.

\begin{tabular}{|c|c|c|c|c|}
\hline Characteristic & Parameter & $\begin{array}{l}\text { All patients } \\
(n=33)\end{array}$ & $\begin{array}{l}\text { Subgroup } 1 \\
(\mathrm{n}=27)\end{array}$ & $\begin{array}{l}\text { Subgroup } 3 \\
(n=31)\end{array}$ \\
\hline \multirow[t]{3}{*}{ Age } & mean & 66.6 & 68.2 & 67.3 \\
\hline & SD & 7.5 & 6.9 & 7.1 \\
\hline & range & $53.9-82.6$ & $55.8-82.6$ & $53.9-82.6$ \\
\hline \multirow[t]{3}{*}{ PSA } & mean & 8.2 & 8.5 & 8.2 \\
\hline & SD & 3.0 & 3.1 & 3.0 \\
\hline & range & $5.1-16.4$ & $5.2-16.4$ & $5.1-16.4$ \\
\hline \multirow[t]{3}{*}{ PSAV } & mean & 3.0 & 3.1 & 3.0 \\
\hline & SD & 2.5 & 2.6 & 2.5 \\
\hline & range & $0.7-12.8$ & $0.9-12.8$ & $0.7-12.8$ \\
\hline \multirow[t]{3}{*}{ PSA\% } & mean & 21.7 & 23.8 & 22.5 \\
\hline & SD & 8.5 & 7.4 & 8.2 \\
\hline & range & $4-45$ & $12-45$ & $4-45$ \\
\hline \multirow[t]{3}{*}{ PSAD } & mean & 0.2 & 0.2 & 0.2 \\
\hline & SD & 0.1 & 0.1 & 0.1 \\
\hline & range & $0.1-0.4$ & $0.1-0.4$ & $0.1-0.4$ \\
\hline \multirow[t]{3}{*}{ IPSS } & mean & 6.8 & 7.4 & 7.1 \\
\hline & SD & 4.3 & 4.3 & 4.3 \\
\hline & range & $1-16$ & $1-16$ & $1-16$ \\
\hline \multirow[t]{3}{*}{$P \operatorname{det} Q_{\max }$} & mean & 80.3 & 77.4 & 78.2 \\
\hline & SD & 24.5 & 23.0 & 21.8 \\
\hline & range & $40-150$ & $40-140$ & $40-140$ \\
\hline \multirow[t]{3}{*}{$\mathrm{nEPB}$} & mean & 1.7 & 1.7 & 1.7 \\
\hline & SD & 0.9 & 1.0 & 0.9 \\
\hline & range & $1-5$ & $1-5$ & $1-5$ \\
\hline
\end{tabular}

PSA = Prostate specific antigen; PSAV = PSA velocity; PSA\% = percentage of free PSA; PSAD = PSA density; IPSS = international prostate symptoms score; $\mathrm{nEPB}=$ number of extended prostate biopsies; PdetQmax= detrusor pressure at maximum flow.

Subgroup 1 = patients with benign prostate hyperplasia. Subgroup $3=$ patients without signs of aggressive prostate cancer. 
For IPSS before TURP, a mean value in all patients of $6.8 \pm 4.3$ was obtained. In subgroup 1 and subgroup 3, mean IPSS values before TURP were $7.4 \pm 4.3$ and $7.1 \pm 4.3$, respectively.

The mean value for $P_{\text {det }} Q_{\max }$ in all patients was $80.3 \pm 24.5 \mathrm{~cm} \mathrm{H}_{2} \mathrm{O}$. In all cases, patients underwent an average of $1.7 \pm 0.9$ prostate biopsy procedures, which corresponded well with the data obtained for the different subgroups (Table 5.1).

\section{Histology}

After TURP, histological examination showed only BPH in 27 patients (81.8\%). This group of patients with no evidence of invasive prostate cancer is referred to as subgroup 1. For 2 patients (6.1\%), histological analysis showed aggressive prostate cancer [Gleason value of the first patient was $4+4=8$, of the second patient $3+3=6$; combined with greater amount of cancer cells (in both patients, $1 \mathrm{~g}$ of resected tissue was cancerous) and/or relative young age]. This group is referred to as subgroup 2 . These 2 patients were treated with radical retropubic prostatectomy three months after TURP because of the histological characteristics of their resected tissue and their relative young age (Table 5.2). The remaining 4 patients $(12.1 \%)$ showed a small amount of unaggressive prostate cancer cells (lower Gleason value and/or relative older age): T1a prostate cancer (Gleason value $3+3=6 / 10$ ) was found in a few chips with low malignant potential (Table 5.2). These patients, together with the 27 patients with no evidence of invasive prostate cancer (subgroup 1) (a total of 31 patients; 93.9\%), are called subgroup 3. 
Table 5.2. Histological data in patients with prostate cancer (aggressive and unaggressive).

\begin{tabular}{|c|c|c|c|c|c|c|}
\hline Patient age (years) & 63 & 54 & 60 & 68 & 55 & 54 \\
\hline Preop PSA & 5.8 & 9.9 & 5.7 & 5.1 & 9.2 & 5.4 \\
\hline Preop PSA\% & 19 & 4 & 21 & 13 & 13 & 9 \\
\hline Preop PSAD & 0.3 & 0.4 & 0.2 & 0.4 & 0.4 & 0.4 \\
\hline Preop PSAV & 1.2 & 45.0 & 3 & 0.7 & 1.9 & 0.7 \\
\hline preop IPSS & 4 & 3 & 10 & 2 & 3 & 3 \\
\hline nEPB & 3 & 2 & 1 & 2 & 1 & 1 \\
\hline$P_{\text {detQ }} Q_{\max }$ & 75 & 80 & 100 & 80 & 150 & 75 \\
\hline Weight (g) & 37 & 20 & 47 & 32 & 18 & 26 \\
\hline \multirow{3}{*}{$\begin{array}{l}\text { TURP/histological } \\
\text { examination }\end{array}$} & 1 chip $3+3=6 / 10$ & 2 chips $3+3=6 / 10$ & 4 chips $3+3=6 / 10$ & 10 chips $3+3=6 / 10$ & $1 \mathrm{~g} 4+4=8 / 10$ & $1 \mathrm{~g} 3+3=6 / 10$ \\
\hline & HPIN++ & HPIN & HPIN++ & $\begin{array}{l}\text { HPIN+ } \\
\text { prostatitis }\end{array}$ & $\begin{array}{l}\text { tertiary pattern } 3 \\
\text { HPIN++ }\end{array}$ & HPIN+ \\
\hline & T1aG2 & $\mathrm{T} 1 \mathrm{aG} 2$ & T1aG2 & $\mathrm{T} 1 \mathrm{aG} 2$ & T1aG3 & $\mathrm{T} 1 \mathrm{aG} 2$ \\
\hline PSA 6 months & 0.5 & 1.5 & 0.5 & 0.1 & $<0.01$ & $<0.01$ \\
\hline IPSS 6 months & 0 & 1 & 4 & 1 & 1 & I \\
\hline $\begin{array}{l}\text { further therapy = } \\
\text { RRP }\end{array}$ & I & / & I & I & $\begin{array}{l}2 \text { residual foci } \\
4+3=7 / 10 \\
\text { neg surgical margins } \\
\text { peripheral } \\
\text { T2aG3N0 }\end{array}$ & $\begin{array}{l}1 \text { residual focus } \\
3+3=6 / 10 \\
\text { neg surgical margins } \\
\text { peripheral } \\
\text { T2aG2NO }\end{array}$ \\
\hline
\end{tabular}

Preop = preoperative; PSA = prostate specific antigen; PSA\% = percentage of free/total PSA; PSAD = PSA density; PSAV = PSA velocity; IPSS = international prostate symptoms score; $\mathrm{nEPB}=$ number of extended prostate biopsies; $\mathrm{Pdet}_{\max }=$ detrusor pressure at maximal flow; $\mathrm{TURP}=$ transurethral resection of the prostate; PSA 6 months = PSA value 6 months postoperatively; IPSS 6 months = IPSS 6 months postoperatively; RRP = radical retropubic prostatectomy; HPIN = high-grade prostatic intraepithelial neoplasia. 
High-Grade Prostatic Intraepithelial Neoplasia (HPIN) was found in 5 patients including the 2 patients of subgroup 2. The other three patients with HPIN were patients from subgroup 1. Mean weight in all cases was $53.5 \pm 27.5 \mathrm{~g}$; in subgroup 1 and subgroup 3 a mean weight of $58.7 \pm 27.4 \mathrm{~g}$ and $55.5 \pm 27.1 \mathrm{~g}$ was measured, respectively. Moderate signs of prostatitis were found in 5 patients (15.1\%).

\section{PSA and functional outcome}

Mean PSA value post-TURP in subgroup 1 was $0.6 \pm 0.7 \mathrm{ng} / \mathrm{ml}$ and $0.6 \pm 0.6$ $\mathrm{ng} / \mathrm{ml}$ in subgroup 3 (Figure 5.1a). Six months after TURP, mean IPSS in subgroup 1 and subgroup 3 amounted to $2.5 \pm 1.9$ and $2.4 \pm 1.8$, respectively (Figure 5.1b). Mean results for quality of life (QOL) in subgroup 1 was 0.7 (preTURP 1.8) and 0.6 (pre-TURP 1.7) in subgroup 3 (Figure 5.1c).

In 7 randomly chosen patients of subgroup 3, a postoperative urodynamic evaluation was performed. In these patients, the mean value for $P_{\text {det }} Q_{\max }$ post-TURP was $16.4 \mathrm{~cm} \mathrm{H}_{2} \mathrm{O}$ (range $15-20 \mathrm{~cm} \mathrm{H}_{2} \mathrm{O}$ ). The pre-TURP mean value in this group was $85.0 \mathrm{~cm} \mathrm{H}_{2} \mathrm{O}$ (range $70-110 \mathrm{~cm} \mathrm{H}_{2} \mathrm{O}$ ).

A positive correlation was observed between PSAV and Pdet $_{\max }$, with $r=$ $0.5278(P=0.007)$ for subgroup 1 and $r=0.5014(P=0.006)$ for subgroup 3 (Table 5.3). Additionally, a positive correlation was discovered between PSAV and peak flow within six months after TURP $[r=0.5923(P=0.002)$ and $r=$ $0.5178(P=0.005)$ for subgroup 1 and subgroup 3 , respectively]. Finally, Pdet $_{\max }$ and peak flow within six months after TURP were observed to be positively correlated as well (Table 5.3). 
Table 5.3. Correlation between $P S A V, P d e t Q_{\max }$ and peak flow for all patients and the different subgroups.

\begin{tabular}{llll}
\hline Group & Variables & $\begin{array}{l}\text { Correlation } \\
\text { factor }\end{array}$ & p value \\
\hline Total $(n=33)$ & PSAV/PdetQ $_{\max }$ & 0.5014 & 0.006 \\
Subgroup 1 $(n=27)$ & PSAV/PdetQ $_{\max }$ & 0.5278 & 0.007 \\
Subgroup 3 $(n=31)$ & PSAV/PdetQ $_{\max }$ & 0.5014 & 0.006 \\
\hline Total $(n=33)$ & PSAV/peak flow & 0.5178 & 0.005 \\
Subgroup 1 $(n=27)$ & PSAV/peak flow & 0.5923 & 0.002 \\
Subgroup 3 $(n=31)$ & PSAV/peak flow & 0.5178 & 0.005 \\
\hline Total $(n=33)$ & PdetQ $_{\max } /$ peak flow & 0.3935 & 0.031 \\
Subgroup 1 $(n=27)$ & PdetQ $_{\max } /$ peak flow & 0.4437 & 0.023 \\
Subgroup 3 $(n=31)$ & PdetQ $_{\max } /$ peak flow & 0.3935 & 0.031 \\
\hline
\end{tabular}

Peak flow $=$ peak flow within 6 months after TURP; PSAV = PSA velocity; $P \operatorname{det} Q_{\max }=$ detrusor pressure at maximal flow.

Subgroup 1 = patients with benign prostate hyperplasia. Subgroup $3=$ patients without signs of aggressive prostate cancer. 
a)

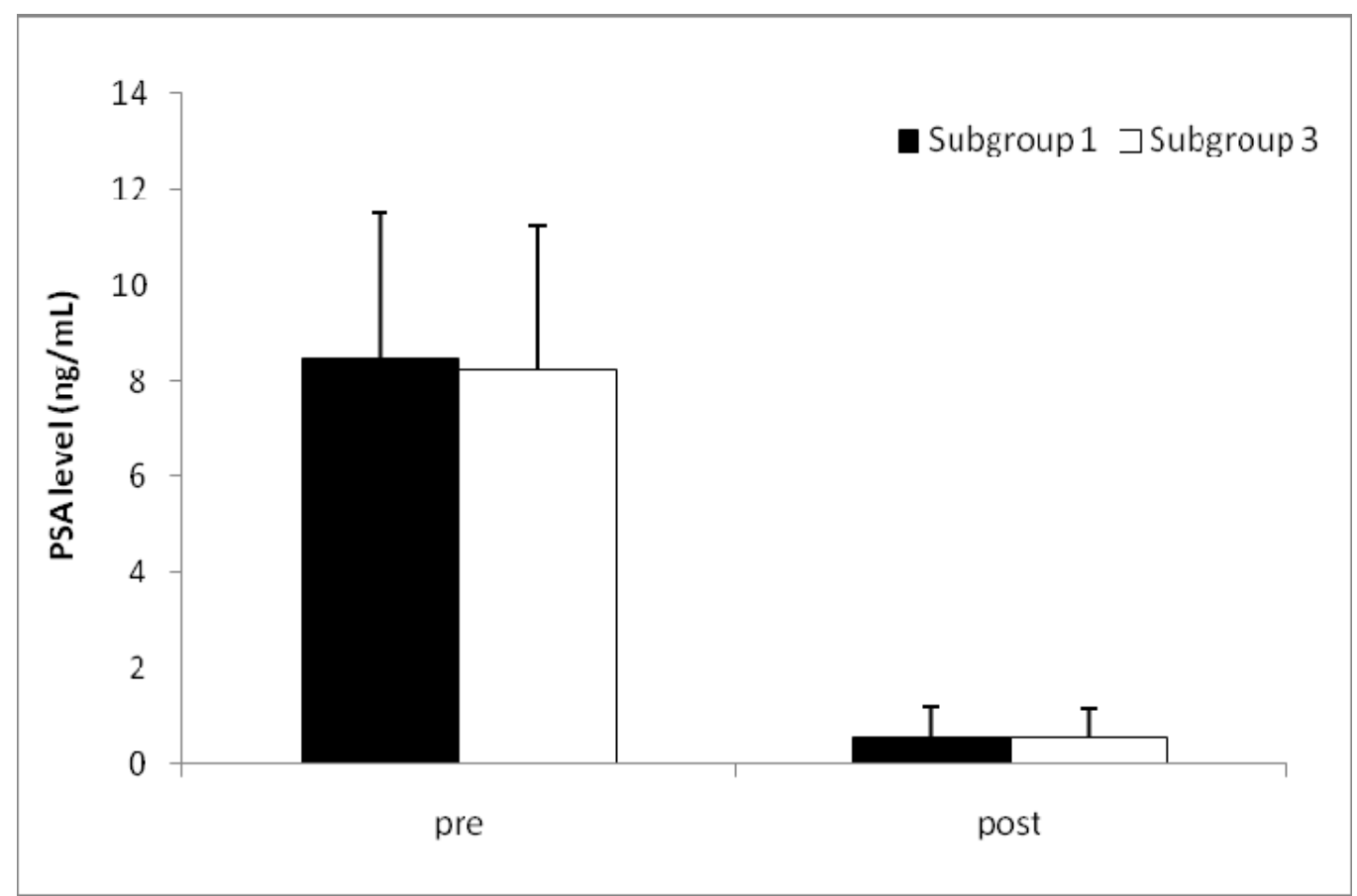

b)

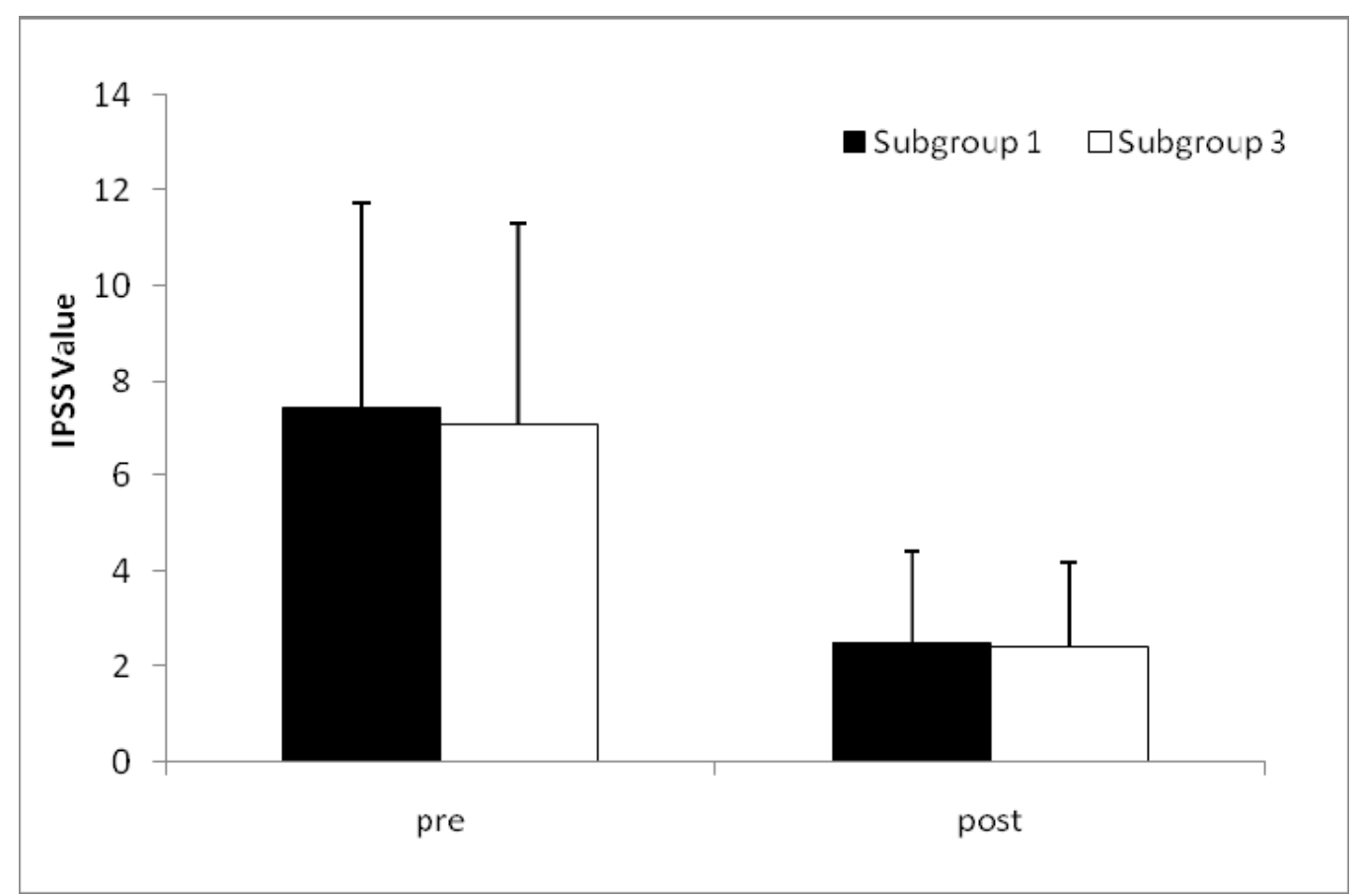


c)

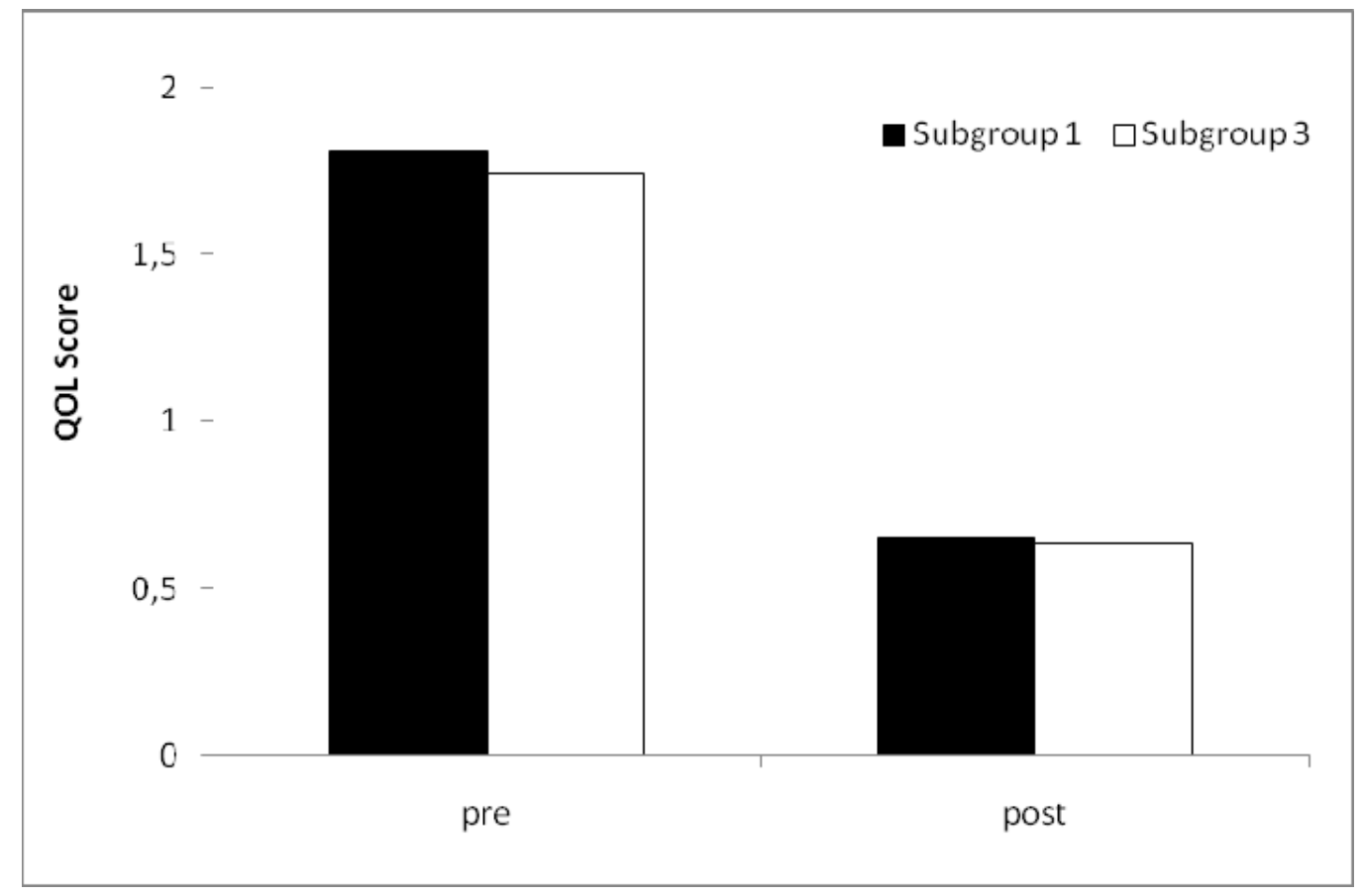

Figure 5.1. Pre- and postoperative evaluation of patients undergoing transurethral resection of the prostate (TURP): a) PSA level, b) IPSS c) QoL. Subgroup 1 = patients with benign prostate hyperplasia. Subgroup 3 = patients without signs of aggressive prostate cancer. 


\section{Discussion}

Patients with elevated and/or rising PSA levels are often referred to an urologist. When these elevated PSA levels coincide with cancer-suspicious DRE and TRUS examinations and when extended prostate biopsies show malignancy, treatment strategy is normally straightforward. However, when DRE and TRUS outcomes are not suspicious for prostate cancer and (multiple) extended prostate biopsies do not reveal a T1c prostate cancer, decision on which policy to follow remains unclear, especially if patients have minor LUTS and follow-up shows a persistent or even a rising PSA level [13][14].

In order to deal with this problem, a large numbers of strategies and biopsy regimens have been developed. Catalona and co-workers [15] promoted the use of free PSA\% and PSAD with a cut-off value of $25 \%$ or less for free PSA\% and 0.078 for PSAD. The group of Berger [6] put forward the use of PSAV, for which they suggested a cut-off value of $0.98 \mathrm{ng} / \mathrm{ml} /$ year. The group of Loeb [16] advised a cut-off value of $0.4 \mathrm{ng} / \mathrm{ml} /$ year in patients younger than 60 years.

With regard to extended prostate biopsies, different regimens have been suggested. Durkan [7] promoted an extended core biopsy protocol with twelve cores which improved prostate cancer detection rate. Arnold and his group [17] obtained a $13.5 \%$ extra detection rate with an extended sector 12 -cores biopsy scheme. More recently, Guichard and co-workers [1] presented results of a 21 sample biopsy protocol. Prostate cancer occurrence in a subset of patients with normal DRE was $33.8 \%$ in sextant with 6 lateral biopsies. This increased to $38.2 \%$ when applying a 21 samples strategy. 
Despite these different strategies, a number of patients with negative (multiple) prostate biopsies and a persistent elevated/rising PSA will remain. In the study of Guichard and co-workers, a residual group of patients with negative biopsies existed (61.8\%) [1]. Furthermore, Djavan[2] showed that this group of patients should not be biopsied continuously. Previous work from our group showed that in this remaining group of patients with elevated and/or rising PSA, normal DRE and TRUS, minor LUTS and (multiple) negative prostate biopsies, BOO can be suspected [4]. Additionally, it has been shown that these patients are at a higher risk for acute urinary retention and BPH related surgery [3][4]. Roehrborn and colleagues [18] came to the same conclusions in a group of patients with moderate to severe LUTS. They proposed to consider earlier surgical treatment [19]. Mochtar and co-workers [20] showed that PSA is a significant prognostic factor for invasive treatment. Additionally, the EAU guidelines state that BPH can be considered a progressive disease [21]. Moreover, a group of patients at increased risk of progression can be identified based on specific risk factors, i.e. age, PSA level and prostate volume [22]. It might be appropriate to identify these patients at risk of progression and initiate early preventative treatment.

As mentioned before, all patients in this study were proven to have BOO according to Abrams-Griffiths definition of obstruction [9]. After proposing and discussing the procedure of TURP to the patient, including full information on possible sexual dysfunction such as retrograde ejaculation, all patients agreed to undergo the procedure. Multiple reasons for using TURP to solve BOO can be given. Firstly, BOO -if not treated-can lead to fatigue of the detrusor muscle or even to renal insufficiency [23]. Secondly, medical treatment has been proven to have no effect on PSA level in case of $\alpha 1$-blockers and results in a 
heterogeneous PSA response in case of $5-\alpha$ reductase inhibitors [24]. Furthermore, as we know that transition zone cancers are frequently associated with separate, larger and higher grade peripheral zone prostate cancers [25], TURP allows a more exhaustive histological examination. Additionally, since long-term medical treatment does not provide cure, the economic benefit of TURP should be considered [26]. Moreover, it has been proven that TURP can no longer be considered as an aggressive treatment given the low complication rate. Wendt-Nordahl and Reich [27][28] even wonder if TURP should still be considered as "an invasive procedure". Finally, long term results of a TURP are excellent in comparison with medical treatment for a lifelong condition in an ageing population [29].

In this study, histological examination after TURP showed pure BPH in 27 patients (81.8\%). A small amount of unaggressive prostate cancer cells (moderate Gleason value of cancer cells) was encountered in 4 patients (12.1\%). Patients with pure BPH were submitted to close surveillance together with the patients with "unaggressive prostate cancer", who were treated conservatively [11][12]. In subgroup 3, consisting of 31 patients, PSA levels dropped from 8.2 to $0.6 \mathrm{ng} / \mathrm{ml}$ (range $0.1-2.9 \mathrm{ng} / \mathrm{ml}$ ) within six months after TURP, suggesting that $\mathrm{BOO}$ was the main reason of the PSA elevation. In the same subgroup, preoperative IPSS was 7.1 (range 1-16) and dropped to 2.4 (range 0-8) within six months. The QOL score dropped from 1.7 to 0.6 , indicating that patients were satisfied with the result of their TURP [30]. In subgroup 3, $\mathrm{Pdet}_{\max }$ normalised with a mean value of $16.4 \mathrm{~cm} \mathrm{H}_{2} \mathrm{O}$ (range 15$20 \mathrm{~cm} \mathrm{H} \mathrm{H}_{2} \mathrm{O}$ ) which was obtained in 7 random cases (preoperative mean $85 \mathrm{~cm}$ $\mathrm{H}_{2} \mathrm{O}$; range $70-110 \mathrm{~cm} \mathrm{H}_{2} \mathrm{O}$ ). 
In 2 patients (6.1\%), aggressive prostate cancer was detected after TURP (Table 5.2). Three months later, these two patients underwent a radical retropubic prostatectomy without major technical difficulty [31]. Histological examination of the prostate confirmed our retrospective analysis [5] of residual prostate cancer in the (lateral/anterior) peripheral zone. Both patients had a T2a stage and had a PSA value $<0.01 \mathrm{ng} / \mathrm{ml} 3$ months after radical retropubic prostatectomy. Therefore we also suggest to discuss a TURP in this particular group of patients even with very little symptoms (e.g.: IPSS = 1). This implies that we would not recommend vaporisation in these patients since this technique does not allow histological examination of the tissue.

Finally, in subgroup 3, a positive correlation between PSAV and $\mathrm{PdetQ}_{\max }(r=$ $0.5014, P=0.006$ ) was found. This value was clearly influenced by one patient (outlier). It is our belief that even this patient is not an accidental coincidence since his PSAV of $12.8 \mathrm{ng} / \mathrm{ml} /$ year matched a very high $P \operatorname{det} Q_{\max }\left(140 \mathrm{~cm} \mathrm{H}_{2} \mathrm{O}\right)$. His PSA decreased from $16.4 \mathrm{ng} / \mathrm{ml}$ preoperatively to $1.6 \mathrm{ng} / \mathrm{ml}$ post TURP. Histological examination showed BPH with no signs of prostate cancer neither HPIN nor inflammation. However, it should be noted that this study is limited by the sample size and that a reliable assessment of differences between subgroups was not possible due to the low number of (mostly) overlapping of patients. Therefore, more patients need to be studied to confirm this result. 


\section{Conclusion}

Patients with elevated and/or rising PSA, minor LUTS and no prostate cancer on (multiple) extended prostate biopsies present a challenging problem in urological practice. Since these patients can be expected to have BOO, a TURP should be discussed with the patient if $\mathrm{BOO}$ is confirmed. In favour of performing a TURP, both an expected "super" normalisation of PSA and a symptomatical benefit in terms of IPSS and QOL are determined. Importantly, extensive histological examination can diagnose aggressive and curable prostate cancer at early stage. However, more studies with a higher number of patients are needed to confirm these results.

\section{Acknowledgements}

The authors wish to thank Dr Sven Deferme and Dr Rita Aert who provided medical writing services on behalf of PharmaXL. 


\section{References}

[1] Guichard G, Larrré S, Gallina, et al. Extended 21-Sample Needle Biopsy Protocol for Diagnosis of Prostate Cancer in 1000 Consecutive Patients. Eur Urol 2007;52:430-435.

[2] Djavan B, Ravery V, Zlotta A, et al. Prospective evaluation of prostate cancer detected on biopsies 1, 2, 3 and 4: When should we stop? J Urol 2001;166:1679-1683.

[3] Laniado M, Ockrim J, Marronaro A, et al. Serum prostate-specific antigen to predict the presence of bladder outlet obstruction in men with urinary symptoms. BJU Int 2004; 94:1283-1286.

[4] Van Renterghem K, Van Koeveringe G, Van Kerrebroeck P. Rising PSA in patients with minor LUTS without evidence of prostatic carcinoma: a missing link? Int Urol Nephrol 2007;39:1107-1113.

[5] Van Renterghem K, Van Koeveringe G, Achten R, Van Kerrebroeck P. Clinical Relevance of Transurethral Resection of the Prostate in "Asymptomatic" patients with an Elevated Prostate-Specific Antigen Level. Eur Urol 2007;52:819-826.

[6] Berger A, Deibl M, Strasak A, et al. Large-Scale Study of Clinical Impact of PSA Velocity: Long-Term PSA Kinetics as Method of Differentiating Men with from Those without Prostate Cancer. Urology 2007;69:134-138.

[7] Durkan GC, Sheikh N, Johnson P, et al. Improving prostate cancer detection with an extended-core transrectal ultrasonography-guided prostate biopsy protocol. BJU Int 2002;89:33-39.

[8] Boccon-Gibod L, van der Kwast TH, Montironi R, et al. Handling and pathology reporting of prosate biopsies. Eur Urol 2004:46:177-181.

[9] Griffiths D, Höfner K, van Mastrigt R, et al. Standardization of terminology of lower urinary tract function: Pressure-flow studies of voiding, urethral resistance, and urethral obstruction. Neurourol Urodyn 1997;16:1-18.

[10] Rosai J. Ackerman's surgical pathology. ed. 9, Mosby Year Book. St. Louis; 2004.

[11] Eastham J, Kattan M, Fearn P, et al. Local Progression among Men with Conservatively Treated Localized Prostate Cancer: Results from the Transatlantic Prostate Group. Eur Urol 2008;53:347-354.

[12] Cheng L, Bergstralh EJ, Scherer BG, et al. Predictors of cancer progression in T1a prostate adenocarcinoma. Cancer. 1999;85:1300-1304. 
[13] Bratt O. The difficult case in prostate cancer diagnosis-when is a "diagnostic TURP" indicated? Eur Urol. 2006;49(5):769-771.

[14] Puppo P, Introini C, Calvi P, Naselli A. Role of transurethral resection of the prostate and biopsy of the peripheral zone in the same session after repeated negative biopsies in the diagnosis of prostate cancer. Eur Urol. 2006;49(5):873-878.

[15] Catalona WJ, Southwick PC, Slawin KM, et al. Comparison of percent free PSA, PSA density and age specific PSA cut-offs for prostate cancer detection and staging. Urology $2000 ; 56: 255-260$.

[16] Loeb S, Roehl KA, Catalona WJ, Nadler RB. Prostate Specific Antigen Velocity Threshold for Predicting Prostate Cancer in Young Men. J Urol 2007; 177:899-902.

[17] Arnold P, Niemann T, Bahnson R. Extended sector biopsy for detection of carcinoma of the prostate. Urol Oncol 2001;6:91-93.

[18] Roehrborn C, McConnell J, Lieber M, et al. Serum prostate-specific antigen concentration is a powerful predictor of acute urinary retention and need for surgery in men with clinical benign prostatic hyperplasia. Urology 1999;53:473-480.

[19] Roehrborn C, McConnell J, Bonilla J, et al. Serum prostate specific antigen is a strong predictor of future prostate growth in men with benign prostatic hyperplasia. J Urol 2000;163:13-20.

[20] Mochtar CA, Kiemeney LALM, Laguna MP, et al. Prognostic role of prostate-specific antigen and prostate volume for the risk of invasive therapy in patients with benign prostatic hyperplasia initially managed with Alpha1-blockers and watchful waiting. J Urol 2004;300-305.

[21] Section 1.2.2 of the EAU guidelines, http://www.uroweb.org/fileadmin/user_upload/ Guidelines/BPH.pdf.

[22] Roehrborn CG. BPH progression: concept and key learning from MTOPS, ALTESS, COMBAT and ALF-ONE. BJU Int 2008:101 S3:17-21.

[23] Rule $A D$, Lieber $M M$, Jacobsen SJ. Is benign prostatic hyperplasia a risk factor for chronic renal failure? J Urol 2005;173:691-696.

[24] Brawer MK, Lin DW, Williford WO, et al. Effect of Finasteride and/or Terazosin on serum PSA: results of VA cooperative study \#359: The Prostate 1999;39:234-239. 
[25] Noguchi M, Stamey TA, Neal JE, Yemoto CE. An analysis of 148 consecutive transition zone cancers: clinical and histological characteristics. J Urol 2000;163:1751-1755.

[26] Teillac P, Scarpa RM: Economic issues in the treatment of BPH. Eur Urol Suppl 2006;1018-1024.

[27] Wendt-Nordahl G, Bucher B, Häcker A, et al. Improvement in mortality and morbidity in transurethral resection of the prostate over 17 years in a single center. J Endourol 2007;21:1081-1087

[28] Reich O, Gratzke C, Stief CG. Techniques and long-term results of surgical procedures for BPH. Eur Urol 2006; 49:970-978.

[29] Madesbacher S, Marszalek M, Lackner J, et al. The Long-Term Outcome of Medical Therapy for BPH. Eur Urol 2007; 51:1522-1533.

[30] Laguna P, Alivizatos G. Prostate specific antigen and benign prostatic hyperplasia. Curr Opin Urol 2000;10:3-8.

[31] Colombo R, Naspro R, Salonia A, et al. Radical Prostatectomy After Previous Prostate Surgery: Clinical and Functional Outcomes. J Urol 2006;176:2459-2463. 
Chapter 6 - A new algorithm in patients with elevated and/or rising prostate-specific antigen level, minor lower urinary tract symptoms and negative multisite prostate biopsies: key role for urodynamics

van Renterghem K, Van Koeveringe G, Achten R, van Kerrebroeck P. Submitted for publication in Neurourology and Urodynamics. 


\section{Abstract}

Patients with elevated and/or rising prostate-specific antigen (PSA), minor lower urinary tract symptoms (LUTS), no evidence for prostate cancer on (multiple) extended prostate biopsies are a regularly encountered problem in urological practice. Even now, patients are seen with no objective explanation of this persistent elevated and/or rising PSA. So far, many strategic proposals have been elaborated and published to deal with this specific population including the use of different PSA derivates; applying different biopsy schemes - strategies - biopsy target imaging; diagnostic use of prostate cancer genes, and many more. In this review we propose a new algorithm in which an urodynamic evaluation should be included since bladder outlet obstruction (BOO) can be expected. Once BOO is confirmed, a transurethral resection of the prostate (TURP) can be offered to these patients. This procedure will result in subjective and biochemical improvement and allows extensive histological examination. Current literature was reviewed with regard to this specific population. This research was performed using the commercially available Medline online search tools and applying the following search terms: "diagnostic TURP"; "elevated PSA"; "prostate biopsy". Furthermore, subsequent reference search was executed on retrieved articles.

\section{Keywords}

Benign Prostatic Hyperplasia (BPH); Bladder Outlet Obstruction (BOO); Prostate Cancer; Transurethral Resection of the Prostate (TURP); Elevated ProstateSpecific Antigen (PSA). 


\section{Introduction}

Twenty five percent of men over 50 years old have lower urinary tract symptoms (LUTS). LUTS may be caused by benign prostatic hyperplasia (BPH), one of the most common diseases among ageing men and the second most common cause of surgery in men over 60 years old [1]. Another condition that might be accompanying LUTS could be prostate cancer (PCa), which has become the most common cancer in men in several developed countries, especially in Western populations and particularly among the black population of the US.

Since the concept of Prostate-Specific Antigen (PSA) has been introduced in clinical practice [2], many patients are referred to an urologist because of elevated and/or rising PSA levels. To find the cause of these elevated and/or rising PSA levels, often extended prostate biopsies are taken. If cancer cells are discovered in the biopsies, therapy is usually straightforward. If however prostate biopsies are negative for cancer cells, numberless diagnostic strategies have put forward. When PSA levels remain high or rise even more, new extended prostate biopsies are usually taken, eventually with different methods. When PSA levels keep on rising and when extended prostate biopsies remain negative in this group of patients, uncertainty will grow for patients, as well as for general practitioners and last but not least for urologists. More specifically, this will be the case if the patient suffers only minor LUTS.

We have previously shown that this group of patients (patients with elevated/and or rising PSA levels, minor LUTS and no signs of prostate cancer) are likely to have bladder outlet obstruction (BOO) on pressure flowmetry 
according to Abrams-Griffiths definition [3][4]. Despite minor to no LUTS, transurethral resection of prostate (TURP) is a therapeutic option that can be offered to patients resulting in (super)normalisation of PSA levels, symptomatic benefit and improvement of the quality of life. Additionally, this technique allows extended histological examination, which will reveal in few cases prostate cancer that can be aggressive and need further treatment. Since patients with elevated and/or rising PSA; minor LUTS; (multiple) negative extended prostate biopsies can be expected to have $\mathrm{BOO}$, we elaborated a new algorithm in which we propose to consider urodynamic evaluation and the possibility of performing a TURP in this group of patients.

\section{What are urologists doing today with patients presenting with elevated and/or rising PSA levels, minor LUTS and no signs of prostate cancer on (multiple) extended prostate biopsies?}

\section{Strategies related to PSA evaluation}

If PSA is elevated and/or rising in a patient with minor LUTS, no signs of prostate cancer on digital rectal examination and/or TRUS and eventually on extended prostate biopsies different PSA derivates have been proposed. A first PSA derivative that can be used is PSA age related levels [5]. However, the use of age-specific PSA cut-off values can result in missing up to $60 \%$ of cancers in men older than 60 years of age [6]. Borer concluded that age specific PSA references did not safely eliminate the need for prostate biopsies in a population aged 60 to 79 years [7].

A second PSA derivate that is regularly used is PSA density. When a cut-off value of 0.078 is used for PSA density, the sensitivity for detection of prostate 
cancer is 95\% [5]. Especially in intermediate PSA levels, PSA density nomograms allow a more precise determination than PSA age related levels [8].

A third very frequently used PSA derivative, which is related to PSA kinetics, is PSA velocity. Despite its frequent use, caution is required as different methods exist to calculate PSA velocity [9]. The best way to calculate PSA velocity is by performing linear regression. However, in routine practice urologists often use the rate of PSA change using the first and last value. The arithmetic equation of PSA change should not be recommended [9]. Carter [10] proposed a cut-off value of $0.75 \mathrm{ng} / \mathrm{ml} / \mathrm{yr}$ for PSA velocity. Since the use of this cut-off value has been shown to result in missing $48 \%$ of prostate cancers, Loeb [11] advised in men younger than 60 years to use a cut-off value of $0.4 \mathrm{ng} / \mathrm{ml} / \mathrm{yr}$. Additionally, Berger [12] showed that PSA velocity increases in the years before diagnosis of prostate cancer which correlates well with the pathological stage and with Gleason scores.

Another PSA derivate that can be used is the PSA ratio. The use of this parameter with a cut-off value of $25 \%$ results in sensitivity of $95 \%$ in prostate cancer diagnosis [5]. Catalona [13] proved that the use of PSA ratio can reduce the number of unnecessarily performed biopsies in men with elevated PSA levels on the condition that cut-off values are well defined. An additional PSA derived parameter was investigated by Froehner who evaluated the value of complexed PSA in comparison to total PSA [14]. Using this parameter, a statistical advantage was detected. However, clinical relevance remains unclear.

Several authors investigated the use of "benign" PSA [15][16][17][18]. BPSA is a "benign" form of free PSA that seems to be increased in patients with BPH. A 
correlation was found with transition zone volume and total prostate volume. However, as is the case with some other PSA derivatives, more studies are needed to confirm its clinical utility.

In addition to these PSA derived parameters, molecular assays are a new tool that can be used to refine difficulties in PSA interpretation. A well described and commercially available molecular assay is the PCA3 assay [19]. PCA3 is a very prostate cancer specific gene also called DD3. When a cut-off value of 35 is used, sensitivity amounted $58-65 \%$ with a specificity of $66-72 \%$ (PSA specificity of 47\%) [19][20][21]. Haese and colleagues performed a prospective, multicentre study including 463 patients with one or two negative biopsies who were scheduled for a repeat biopsy [22]. Aim of the study was to compare the diagnostic accuracy of PCA3 with fPSA\%. With a cut-off value of 35 for PCA3, the probability of a positive repeat biopsy was greater if PCA3 was higher. Deras et al found PCA3 to be independent of prostate volume, serum PSA and number of previous biopsies [23]. Although these assays are promising, there are some disadvantages related to these tests. First of all, it should be emphasized that they cannot be used in a routine screening as they are far more expensive. Secondly, these tests can also give false negative and false positive results. Therefore, more evidence confirming the use and the outcome of these assays is required. Last but not least, in addition to these molecular assays, common extended prostate biopsies are still needed to prove possible prostate cancer. 
Strategies related to technique and prostate biopsy regimen

Numerous publications have been made on techniques of prostate biopsies. Hodge [24] started with ultrasound guided, 6 core random biopsies. Subsequently, Eskew [25] proved 5 region prostate biopsies to be superior to sextant biopsies, resulting in an increasing diagnostic yield. A few years later, a 10 core protocol with laterally directed biopsies together with sextant biopsies was developed by Gore [26]. Arnold [27] extended the biopsy technique to a 12 core regimen. This extension resulted in a $13.5 \%$ increased detection rate of prostate cancer in comparison to sextant biopsies combined with transition zone biopsies [28]. Additional techniques were developed by Matsumoto [29], who described a technique where special attention was taken for deep apical biopsies and Lui [30], who advised on more specific attention for transition zone biopsies. However, other authors have shown that biopsies of transition zone and seminal vesicles resulted in low additional yield in the diagnosis of prostate cancer [31][32][33]. Recently, Guichard [34] proposed a 21 core biopsy protocol. Compared to sextant biopsies, a $22 \%$ improvement in prostate cancer detection rate was observed with a 12 core biopsy. When using a 21 core protocol, the cancer detection rate was further increased to $42.5 \%$ compared to $38.7 \%$ with 12 core biopsies. Scattoni et al [35] reviewed the literature on extended and saturation prostate biopsies and concluded extended biopsies should be performed at first biopsy, saturation biopsies at repeated biopsy. However, Ashley [36] evaluated the diagnostic yield of saturation biopsies. In these latter biopsy protocols, 24 or more biopsy cores are taken. Ultimately, they proved that saturation biopsies did not detect more abnormal pathology than standard biopsies [36]. 
Although prostate biopsies are a standard technique, one has to be aware of the possible complications of this procedure, which are excellently reviewed by Raaijmakers [37]. Minor complications such as hematuria, hemospermia, etc are frequently seen. Severe complications occur less frequently: fever (3.5\%), acute urinary retention (0.4\%) and hospitalisation (0.5\%).

Another dilemma with prostate biopsies is how many repeat biopsies should be taken. Djavan [38][39] investigated the cancer detection rate in repeat biopsies. He observed that prostate cancer detection rate in a first biopsy was 24\%. In a second biopsy, the cancer detection rate lowered to $13 \%$. Prostate cancers found in first and second biopsies were comparable in terms of PSA, grade, stage, cancer volume. Cancer detection rate in biopsies 3 and 4 were far less, $5 \%$ and $4 \%$, respectively.

What to do if extended prostate biopsies remain negative and PSA keeps on rising?

In case prostate biopsies remain negative and PSA keeps on rising at the same time, many urologists treat these patients with antibiotics. However, several authors noticed that inflammation seems to have no effect on PSA [40][41][42], putting the antibiotic treatment in question. Another frequently used strategy is an attempt to normalise PSA with dietary manipulation [43][44][45]. However, these data do not support the hypothesis that dietary manipulation protects against prostate cancer. For example, Eastham [46] showed that fat intake was not associated with PSA levels. Therefore, advocating functional foods or supplements explicitly for cancer control purposes, would currently be premature. 


\section{What has been suggested so far to deal with those patients?}

Several authors [47][48][49][50] showed that PSA can be seen as a marker for $\mathrm{BOO}$, as a predictor of future prostate growth and as a marker for risk of acute urinary retention in patients with LUTS. Furthermore, a correlation was found with an elevated need for surgical treatment of BPH in symptomatic patients [50].

However, the challenging problem are patients with elevated and/or rising PSA, minor LUTS, normal DRE and/or TRUS and (multiple) negative extended prostate biopsies. This problem is well recognised in literature [51][52].

A first attempt to deal with this problem was described by Rovner [53]. He showed that a transurethral sampling of at least 4 quadrant chips together with prostate biopsies in patients with elevated and/or rising PSA levels and negative prostate biopsies did not significantly improve prostate cancer diagnosis. Kitamura [54] evaluated 139 consecutive patients with negative prostate biopsies. These patients received TURP for relief of LUTS implying that these patients were symptomatic. Because 4 of these patients were revealed to have prostate cancer during the follow-up period, the authors concluded that the role of TURP in these patients remained unclear. Zigeuner [55] performed a retrospective analysis in patients with LUTS. All patients had (multiple) negative extended prostate biopsies. Another important characteristic in this group of patients was that besides an elevated PSA level, $21.8 \%$ of these patients had an abnormal DRE. After TURP, prostate cancer was detected in $7.9 \%$ of all cases and in $5.5 \%$ of the patients with a normal DRE. Zigeuner concluded that detection rate was low and that diagnostic yield in asymptomatic men remained unknown [55]. 
Özden [56] evaluated 64 patients with LUTS and normal DRE presenting with elevated PSA levels and negative extended prostate biopsies. When TURP was performed, BPH was encountered in 63 patients, and in 1 patient prostatic intraepithelial neoplasia was detected. Six months after TURP, 7 out of 64 patients still had an elevated PSA level. In 3 of these 7 cases, prostatitis was suggested to be the reason of PSA elevation. One patient seemed to have prostate cancer; the remaining 3 patients were diagnosed having $\mathrm{BPH}$. The long-term follow-up in these 7 patients was unclear.

Radhakrishnan [57] described a retrospective analysis in 14 patients undergoing TURP after at least 2 negative extended prostate biopsies. In $21 \%$ of the subjects, aggressive prostate cancer was encountered. In $50 \%$ of the subjects, PSA values returned to normal after TURP. In 1 patient, repeated prostate biopsies revealed prostate cancer after TURP. Philip [58] presented results in 11 patients with prostate cancer diagnosed in TURP after negative extended prostate biopsies with 24-48 cores. Five of these 11 patients underwent a radical retropubic prostatectomy in which organ confined cancer was found, especially located anteriorly. Additionally, in this group of patients TURP was performed to resolve LUTS. Important to notice in this group of patients is that prostate cancer was mainly located anteriorly.

Puppo [59] described the role of TURP together with biopsies of the peripheral zone in the same session in the diagnosis of prostate cancer after repeated negative biopsies. In this study, a group of 43 patients with at least 2 negative extended prostate biopsies is described. In 35 of the 43 patients, further PSA elevation was shown and these patients underwent new prostate biopsies. In 7 of 35 patients, prostate cancer was shown after repeated prostate biopsies. 
Additionally, 3 patients were lost during the follow-up period and 4 patients had a severe co-morbidity and hence were unable to undergo TURP. The remaining 21 patients were offered TURP together with prostate biopsies of the peripheral zone regardless of BOO. In this group of 21 patients, 14 patients accepted to undergo TURP. In 8 of these 14 patients, prostate cancer was diagnosed and these patients underwent a radical prostatectomy. The remaining 6 patients had no cancer in TURP specimen and were followed with a median follow-up of 9 months. Persistently rising PSA values were noted for 2 out of these 6 patients. However, on repeated prostate biopsies, no signs of prostate cancer were detected. Puppo concluded that TURP together with lateral extended prostate biopsies had a high diagnostic power in patients with previously negative extended prostate biopsies and rising PSA levels [59].

Several authors investigated the value of new imaging techniques that can possibly be used for targeted biopsies. A first new emerging and promising technique is contrast-enhanced ultrasound of the prostate (CEUS). This technique overcomes classical limitations of conventional ultrasonography in the B-mode imaging of parenchymal disease. With CEUS, the blood flow in the prostate can be investigated which will results in a better detection of abnormal micro- and macrovascular lesions. Applying CEUS targeted biopsies, more cancers can be detected in comparison with systematic ultrasound guided biopsies [60][61][62]. In a multicentre European study, this technique was further evaluated [63]. Cancer was visualised and localized in $78 \%$. However, further studies to confirm these results have to be initiated. Other authors performed research on real time elastography (RTE). With this technique, tissue stiffness is investigated as this is related to cancer high cell density. Additionally, RTE can be used for targeted biopsies. However, also for 
this technique further studies are needed to approve the value in prostate cancer imaging and targeted biopsies [64][65][66][67][68]. Another innovative technique in prostate cancer imaging and targeted biopsies is Magnetic Resonance (MR) and MR-guided biopsies of the prostate. This technique is well discussed in a recent review by Pondman et al [69]. However, this technique also needs further evaluation.

In our series of studies $[4][70][71][72]$, we included a population with very specific characteristics that are notwithstanding regularly encountered in a urological practice. Therefore, we investigated patients with elevated and/or rising PSA, minor LUTS, negative DRE and TRUS and (multiple) negative extended prostate biopsies. In this group of patients, we found that BOO is extremely likely to occur [4]. In a retrospective analysis of 82 patients [71], 74 patients were shown to suffer from BPH after TURP. In these 74 patients, only 3 patients (4.1\%) had an equivocal $P$ det $Q_{\max }$ (detrusor pressure at maximum flow) according to Abrams-Griffiths [3], while nearly all patients (95.9\%) were

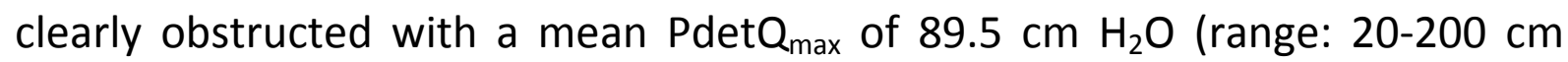
$\mathrm{H}_{2} \mathrm{O}$ ). In a prospective group of 33 patients, mean $\mathrm{Pdet}_{\max }$ was $80.3 \mathrm{~cm} \mathrm{H} \mathrm{H}_{2} \mathrm{O}$ (range: 40-150 $\mathrm{cm} \mathrm{H}_{2} \mathrm{O}$ ) [72]. When TURP was performed in patients with these characteristics, this resulted in a symptomatic benefit (international prostate symptoms score [IPSS]/quality of life) and (super)normalisation of PSA levels both in our retrospective and prospective study [71][72]. Most of the patients seemed to have BPH (retrospective study: 74/82 = 90.2\%; prospective study: $27 / 33=81.8 \%$ ). However, a few subjects suffered aggressive prostate cancer (taking into account the age of the subject, the Gleason score, and the amount of cancer cells) that needed further treatment [73] [74]. This was the case in 7 out of 8 non-BPH patients in the retrospective analysis $(n=82)$ [71] 
and in 2 of 6 non-BPH patients in our prospective analysis $(n=33)$ [72]. On the other hand, in 1 of 8 non-BPH patients $(n=82)$ [71] and in 4 of $6(n=33)$ nonBPH patients [72], unaggressive prostate cancer was found. For these patients, watchful waiting was proposed. These results were confirmed in a long term follow-up analysis with a mean follow-up of 61.5 months. In the same analysis, we found 1 patient (out of 36) who had a persistently rising PSA that resulted in positive extended prostate biopsies 4 years after TURP. This patient received further treatment with radical retropubic prostatectomy and has a tumour free follow-up of 36 months [71].

As already mentioned, in our series of studies, most patients proved to have BPH after TURP (90.2\% retrospective series; $81.8 \%$ in prospective series; $93.9 \%$ in prospective series with no aggressive cancer, only small amount of cancer cells or BPH). This implies that in this particular group of patients even PCA3 testing, saturation prostate, biopsies, CEUS, RTE, and MR guided biopsies will remain negative since there is no cancer to be found. When in this group of patients PSA remains elevated or even rises, confusion will increase and patients cannot be submitted for ever to high-tech, cumbersome, expensive new investigations such as PCA3, CEUS, RTE, or MR. Additionally, it should also be emphasized that even new technologies have false positive and false negative result. Last but not least, most of these new investigations have to be investigated more thoroughly in the future. Considering these remarks, no clear answer will be found in this group of patients explaining the elevated and/or rising PSA levels. Moreover, it should be emphasized that we found in our series that in patients who underwent a radical prostatectomy, cancer was mainly located anteriorly in the peripheral zone, which is not easily accessible for prostate biopsies regardless of the targeting technique. 
Proposal of a new algorithm in patients with elevated and/or rising PSA, minor LUTS, normal DRE and/or TRUS, and (multiple) negative extended prostate biopsies

Patients showing abnormal screening parameters, but with a negative cancer screening result, can be terrified because there is no answer for their abnormal values [75][76][77]. For example, Katz [51] showed that men with abnormal values observed during prostate cancer screening, have an increased cancer related worry and show more problems with sexual function despite their negative biopsy results. Furthermore, we know that medical treatment has no effect on PSA levels (in case of $\alpha 1$ blockers) or a heterogeneous effect on PSA levels (in case of $5 \alpha$ reductase inhibitors) [78][79]. Concerning $5 \alpha$ reductase inhibitors, Brawer showed "the multiply by two rule" is not correct [78].

We also know that if $\mathrm{BOO}$ is not treated, patients are at increased risk of detrusor decompensation and/or renal insufficiency [80][81]. Taking into account the economic aspects of the different treatments for $\mathrm{BPH}$ [82][83][84] and knowing that TURP should no longer be seen as an invasive treatment $[85][86][87][88][89]$, offering TURP to these patients can be a valuable alternative strategy after BOO was proven with urodynamic evaluation since pressure flowstudies can exclude patients who will not benefit from TURP. Moreover, the pressure flowstudies provide great predictive value of clinical improvement after TURP. The worse the degree of BOO, the higher the efficacy of TURP seemed to be [90][91][92][93]. Therefore, we suggest that in these patients with elevated and/or rising PSA level, and/or abnormal PSA velocity, and/or abnormal PSA density, and/or abnormal PSA ratio together with minor LUTS and negative DRE and TRUS, extended prostate biopsies should be taken with at least 12 cores (Figure 6.1). Special attention should be taken for lateral 
and anterior peripheral biopsies as well as transition zone biopsies. If patients suffer from mild LUTS (IPSS 0-7), at least one series of repeated extended prostate biopsy should be taken (Figure 6.1). In patients with moderate LUTS (IPSS 8-19), one well-performed extended prostate biopsy should be sufficient ( $p=0.012[76])$. If extended prostate biopsies remain negative, patients should be offered an urodynamic examination with pressure flow analysis (Figure 6.1). One can expect these patients to have an obstructive pressure flow value (or at least equivocal). In that case, TURP can be discussed and proposed (Figure 6.1). Performing TURP, special attention should be given to the anterior prostate zone.

\section{Conclusion}

Patients with elevated and/or rising PSA, minor LUTS, normal DRE and/or TRUS and (multiple) negative extended prostate biopsies are a conundrum. We showed that in these patients, urodynamics with pressure flowmetry should be performed since BOO can be expected. In this population, we proposed a "diagnostic" TURP with special attention for the anterior prostate. This will probably result in a (super)normalisation of PSA levels and symptomatic benefit, suggesting that BOO, even with minor LUTS, can be seen as a discomfort for patients. However, histological examination will reveal prostate cancer in few cases. This prostate cancer might be aggressive needing further treatment.

\section{Acknowledgements}

The authors wish to thank Dr Sven Deferme who provided medical writing services on behalf of PharmaXL. 


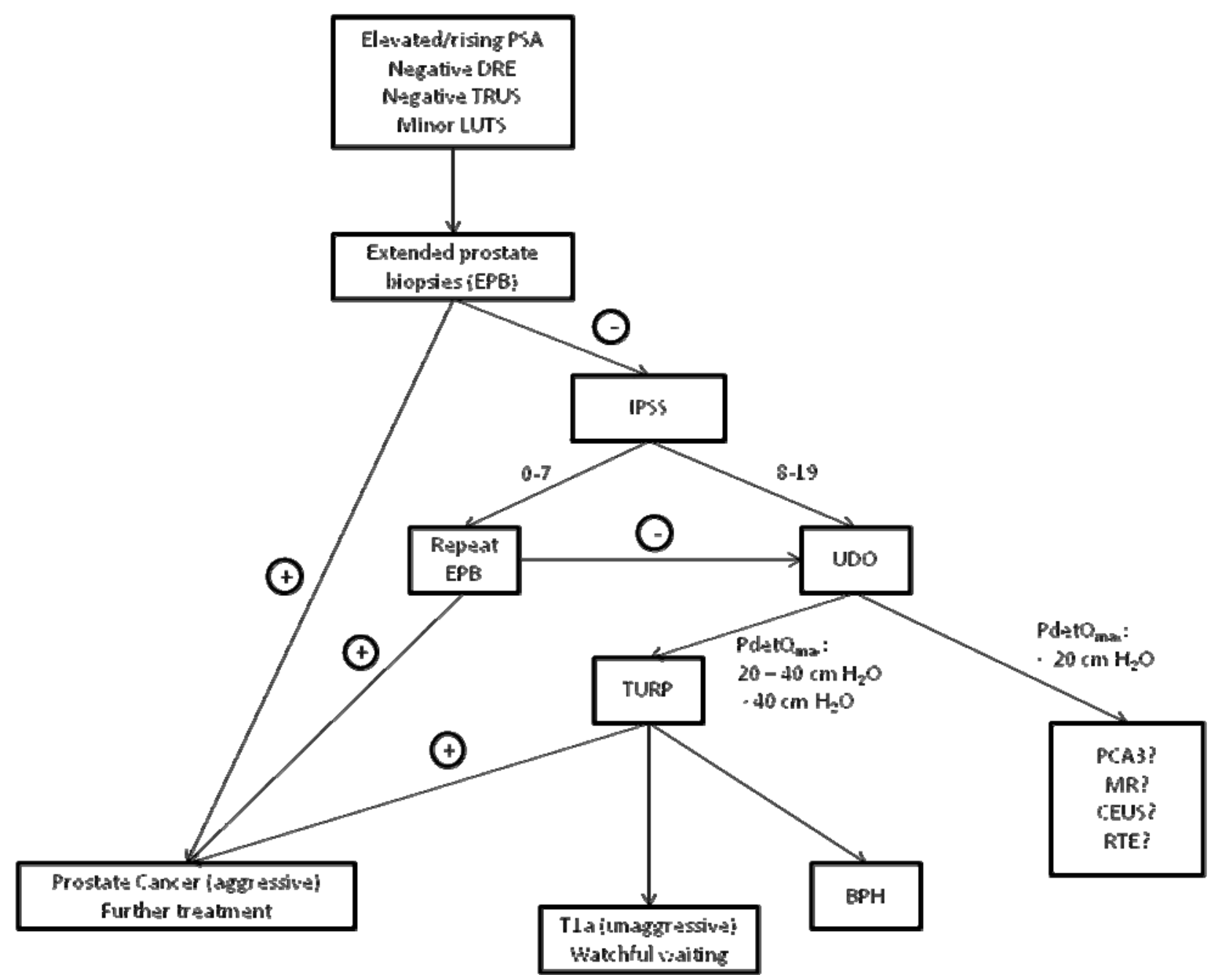

Figure 6.1: Algorithm in patients with elevated and/or rising PSA, minor LUTS, normal DRE and/or TRUS, and (multiple) negative extended prostate biopsies.

PSA: prostate specific antigen; DRE: digital rectal examination; TRUS: transrectal ultrasound; LUTS: lower urinary tract symptoms; EPB: extended prostate biopsies: IPSS: international prostate symptoms score; UDO: urodynamic observations; $P \operatorname{det} Q_{\max }$ : detrusor pressure at maximum flow; TURP: transurethral resection of prostate; BPH: benign prostatic hyperplasia. 


\section{References}

[1] Kirby RS: The clinical assessment of benign prostatic hyperplasia. Cancer 1992;70:284290.

[2] Stamey TA, Yang N, Hay AR, et al: Prostate specific antigen as a serum marker for adenocarcinoma of the prostate. N Engl J Med 1987; 317:909-916.

[3] Griffiths D, Höfner K, van Mastrigt R, et al: Standardization of terminology of lower urinary tract function: Pressure-flow studies of voiding, urethral resistance, and urethral obstruction. Neurourol Urodyn 1997;16:1-18.

[4] van Renterghem K, Van Koeveringe G, Van Kerrebroeck P: Rising PSA in patients with minor LUTS without evidence of prostatic carcinoma: a missing link? Int Urol Nephrol 2007;39:1107-1113.

[5] Laguna P and Alivizatos G: Prostate specific antigen and benign prostatic hyperplasia. Curr Opin Urol 2000;10:3-8.

[6] Catalona WJ, Southwick PC, Slawin KM, et al: Comparison of percent free PSA, PSA density, and age-specific PSA cut-offs for prostate cancer detection and staging. Urology 2000;56:255-260.

[7] Borer JG, Sherman J, Solomon MC, et al: Age specific prostate specific antigen reference ranges: population specific. J Urol 1998;159(2):444-448.

[8] Benson MC, Whang IS, Olsson CA, et al: The use of prostate-specific antigen density to enhance the predictive value of intermediate levels of serum prostate-specific antigen. J. Urol 1992;147:817-821.

[9] Connolly D, Black A, Murray LJ, et al: Methods of calculating Prostate-Specific Antigen velocity. Eur Urol 2007;52:1044-1051.

[10] Carter HB, Pearson JD, Metter JE, et al: Longitudinal evaluation of prostate-specific antigen levels in men without prostate disease. JAMA 1992;267:2215-2220.

[11] Loeb S, Roehl KA, Catalona WJ, et al: Prostate Specific Antigen velocity threshold for predicting prostate cancer in young men. J Urol 2007;177:899-902.

[12] Berger AP, Deibl M, Strasak A, et al: Large-scale study of clinical impact of PSA velocity: long-term PSA kinetics as method of differentiating men with from those without prostate cancer. Urology 2007;69:134-138. 
[13] Catalona W, Smith D, Wolfert R, et al: Evaluation of percentage of free serum prostatespecific antigen to improve specificity of prostate cancer screening. JAMA 1995;274:1214-1220.

[14] Froehner $M$, Hakenberg OW, Koch $R$, et al: Comparison of the clinical value of complexed PSA and total PSA in the discrimination between benign prostatic hyperplasia and prostate cancer. Urol Int 2006;76(1):27-30.

[15] Linton HJ, Marks LS, Millar LS, et al: Benign prostate-specific antigen (BPSA) in serum is increased in benign prostate disease. Clin Chem 2003;49(2):253-259.

[16] Khan MA, Sokoll LJ, Chan DW, et al: Clinical utility of proPSA and "benign" PSA when percent free PSA is less than 15\%. Urology 2004;64(6):1160-1164.

[17] Slawin KM, Shariat S, Canto E: BPSA: A Novel Serum Marker for Benign Prostatic Hyperplasia. Rev Urol 2005;7 Suppl 8:S52-56.

[18] Stephan C, Jung K, Lein M, et al: PSA and other tissue kallikreins for prostate cancer detection. Eur J Cancer 2007;43(13):1918-1926.

[19] Marks LS, Fradet Y, Deras IL, et al: PCA3 molecular urine assay for prostate cancer in men undergoing repeat biopsy. Urology 2007;69:532-535.

[20] Hessels D, Klein Gunnewiek JM, van Oort I, et al: DD3(PCA3)-based molecular urine analysis for the diagnosis of prostate cancer. Eur Urol 2003;44(1):8-15.

[21] van Gils MP, Hessels D, van Hooij O, et al: The time-resolved fluorescence-based PCA3 test on urinary sediments after digital rectal examination; a Dutch multicenter validation of the diagnostic performance. Clin Cancer Res 2007;13(3):939-943.

[22] Haese A, de la Taille A, van Poppel $\mathrm{H}$ et al: Clinical utility of the PCA3 urine assay in European men scheduled for repeat biopsy. Eur Urol 2008;54:1081-1088.

[23] Deras IL, Aubin SM, Blase A, et al: PCA3: a molecular urine assay for predicting prostate biopsy outcome. J Urol 2008;179(4):1587-1592.

[24] Hodge K, McNeal J, Terris M, et al: Random systematic versus directed ultrasound guided transrectal core biopsies of the prostate. J Urol 1989;142:71-75.

[25] Eskew A, Bare R, McCullough D: Systematic 5 region prostate biopsy is superior to sextant method for diagnosing carcinoma of the prostate. J Urol 1997;157:199-203.

[26] Gore JL, Shariat SF, Miles BJ, et al: Optimal combinations of systematic sextant and laterally directed biopsies for the detection of prostate cancer. J Urol 2001;165:15541559. 
[27] Arnold P, Niemann T, Bahnson R: Extended sector biopsy for detection of carcinoma of the prostate. Urol Oncol 2001;6:91-93.

[28] Durkan GC, Sheikh N, Johnson P, et al: Improving prostate cancer detection with an extended-core transrectal ultrasonography-guided prostate biopsy protocol. BJU Int 2002;89: 33-39.

[29] Matsumoto K, Egawa S, Satoh T, et al: Computer simulated additional deep apical biopsy enhances cancer detection in palpably benign prostate gland. Int J Urol 2006;13:1290-1295.

[30] Lui $\mathrm{P}$, Terris $\mathrm{M}$, McNeal J, et al: Indications for ultrasound guided transition zone biopsies in the detection of prostate cancer. J Urol 1995;153:1000-1003.

[31] Bazinet M, Karakiewicz P, Aprikian A, et al: Value of systematic transition zone biopsies in the early detection of prostate cancer. J Urol 1996;155:605-606.

[32] Terris $M$, Pham $T$, Issa $M$, et al: Routine transition zone and seminal vesicle biopsies in all patients undergoing transrectal ultrasound guided prostate biopsies are not indicated. J Urol 1997;157:204-206.

[33] Fleshner $\mathrm{N}$ and Fair $\mathrm{W}$ : Indications for transition zone biopsy in the detection of prostatic carcinoma. J Urol 1997;157:556-558.

[34] Guichard G, Larrré S, Gallina A, et al: Extended 21-sample needle biopsy protocol for diagnosis of prostate cancer in 1000 consecutive patients. Eur Urol 2007;52:430-435.

[35] Scattoni V, Zlotta A, Montironi R, et al: Extended and saturation prostatic biopsy in the diagnosis and characterisation of prostate cancer: a critical analysis of the literature. Eur Urol 2007;52(5):1309-1322.

[36] Ashley RA, Inman BA, Routh JC, et al: Reassessing the diagnostic yield of saturation biopsy of the prostate. Eur Urol 2008;53:976-983.

[37] Raaijmakers R, Kirkels W, Roobol M, et al: Complication rates and risk factors of 5802 transrectal ultrasound-guided sextant biopsies of the prostate within a populationbased screening program. Urology 2002;60:826-830.

[38] Djavan B, Ravery V, Zlotta A, et al: Prospective evaluation of prostate cancer detected on biopsies 1,2,3 and 4: when should we stop? J Urol 2001;166:1679-1683. 
[39] Djavan B, Fong YK, Ravery V, et al: Are repeat biopsies required in men with PSA levels $<$ or $=4 \mathrm{ng} / \mathrm{ml}$ ? A multiinstitutional prospective European study. Eur Urol 2005;47:3844.

[40] Morote J, Lopez M, Encabo G, et al: Effect of inflammation and benign prostatic enlargement on total and percent free serum prostatic specific antigen. Eur Urol 2000;37:537-540.

[41] Nickel JC, Young DI, Boag S: Asymptomatic inflammation and/or infection in benign prostatic hyperplasia. BJU Int 1999;84:976-981.

[42] Chang S, Kim C, Jeon S, et al: Is chronic inflammatory change in the prostate the major cause of rising serum prostate-specific antigen in patients with clinical suspicion of prostate cancer? Int J Urol 2006;13:122-126.

[43] Demark-Wahnefried W and Moyad MA: Dietary intervention in the management of prostate cancer. Curr Opin Urol 2007;17(3):168-174.

[44] Jatoi A, Burch P, Hillman D, et al: A tomato-based, lycopene-containing intervention for androgen-independent prostate cancer: results of a phase II study from the North Central Cancer Treatment group. Urology 2007;69(2):289-294.

[45] Kirsh VA, Mayne ST, Peters U, et al: A prospective study of lycopene and tomato product intake and risk of prostate cancer. Cancer Epidemiol Biomarkers Prev 2006;15(1):92-98.

[46] Eastham JA, Riedel E, Latkany L, et al: Dietary manipulation, ethnicity, and serum PSA levels. Urology 2003;289(20):677-682.

[47] Laniado M, Ockrim J, Marronaro A, et al: Serum prostate-specific antigen to predict the presence of bladder outlet obstruction in men with urinary symptoms. BJU Int 2004;94(9):1283-1286.

[48] Roehrborn C, McConnell J, Lieber M, et al: Serum prostate-specific antigen concentration is a powerful predictor of acute urinary retention and need for surgery in men with clinical benign prostatic hyperplasia. Urology 1999;53(3):473-480.

[49] Roehrborn C, McConnell J, Bonilla J, et al: Serum prostate specific antigen is a strong predictor of future prostate growth in men with benign prostatic hyperplasia. J Urol 2000;163:13-20. 
[50] Mochtar CA, Kiemeney LALM, Laguna MP, et al: Prognostic role of prostate-specific antigen and prostate volume for the risk of invasive therapy in patients with benign prostatic hyperplasia initially managed with alpha1-blockers and watchful waiting. Urology 2005;65(2):300-305.

[51] Bratt O: The difficult case in prostate cancer diagnosis - when is a "diagnostic TURP" indicated. Eur Urol 2006;49:769-771.

[52] Puppo P: Repeated negative prostate biopsies with persistently elevated or rising PSA: a modern urologic dilemma. Eur Urol 2007;52(3):639-641.

[53] Rovner E, Schanne F, Malkowicz B, et al: Transurethral biopsy of the prostate for persistently elevated or increasing prostate specific antigen following multiple negative transrectal biopsies. J Urol 1997;158:138-142.

[54] Kitamura $\mathrm{H}$, Masumori N, Tanuma $\mathrm{Y}$, et al: Does transurethral resection of the prostate facilitate detection of clinically significant prostate cancer that is missed with systematic sextant and transition zone biopsies? Int J Urol 2002;9:95-99.

[55] Zigeuner R, Schips L, Lipsky K, et al: Detection of prostate cancer by TURP or open surgery in patients with previously negative transrectal prostate biopsies. Urology 2003;62(5):883-887.

[56] Özden C, Inal G, Asan Ö, et al: Detection of prostate cancer and changes in prostatespecific antigen (PSA) six months after surgery for benign prostatic hyperplasia in patients with elevated PSA. Urol Int 2003;71:150-153.

[57] Radhakrishnan S, Dorkin TJ, Sheikh N, et al: Role of transition zone sampling by TURP in patients with raised PSA and multiple negative transrectal ultrasound-guided prostatic biopsies. Prostate Cancer Prostatic Dis 2004;7(4):338-342.

[58] Philip J, Dutta Roy S, Scally J, et al: Importance of TURP in diagnosing prostate cancer in men with multiple negative biopsies. Prostate 2005;64:200-202.

[59] Puppo P, Introini C, Calvi P, et al: Role of transurethral resection of the prostate and biopsy of the peripheral zone in the same session after repeated negative biopsies in the diagnosis of prostate cancer. Eur Urol 2006;49:873-878.

[60] Mitterberger M, Pelzer A, Colleselli D, et al: Contrast-enhanced ultrasound for diagnosis of prostate cancer and kidney lesions. Eur J Radiol 2007;64(2):231-238 
[61] Pallwein L, Mitterberger M, Gradl J, et al: Value of contrast-enhanced ultrasound and elastography in imaging of prostate cancer. Curr Opin Urol 2007;17(1):39-47.

[62] Tang J, Yang JC, Luo Y, et al: Enhancement characteristics of benign and malignant focal peripheral nodules in the peripheral zone of the prostate gland studied using contrastenhanced transrectal ultrasound. Clin Radiol 2008;63(10):1086-1091.

[63] Wink M, Frauscher F, Cosgrove D, et al: Contrast-enhanced ultrasound and prostate cancer; a multicentre European research coordination project. Eur Urol 2008;54:982992.

[64] Garra BS: Imaging and estimation of tissue elasticity by ultrasound. Ultrasound Q 2007;23(4):255-268.

[65] Nelson ED, Slotoroff CB, Gomella LG, et al: Targeted biopsy of the prostate: the impact of color Doppler imaging and elastography on prostate cancer detection and Gleason score. Urology 2007;70(6):1136-1140.

[66] Pallwein L, Aigner F, Faschingbauer R, et al: Prostate cancer diagnosis: value of realtime elastography. Abdom Imaging 2008;33:729-735.

[67] Salomon G, Köllerman J, Thederan I, et al: Evaluation of prostate cancer detection with ultrasound real-time elastography: a comparison with step section pathological analysis after radical prostatectomy. Eur Urol 2008;54:1354-1362.

[68] Kamoi K, Okihara K, Ochiai A, et al: The utility of transrectal real-time elastography in the diagnosis of prostate cancer. Ultrasound Med Biol 2008;34(7):1025-1032.

[69] Pondman KM, Fütterer JJ, ten Haken B, et al: MR-guided biopsy of the prostate: an overview of techniques and a systematic review. Eur Urol 2008;54(3):517-527.

[70] van Renterghem K, Van Koeveringe G, Achten R, et al: Clinical relevance of transurethral resection of the prostate in "asymptomatic" patients with an elevated prostate-specific antigen level. Eur Urol 2007;52:819-826.

[71] van Renterghem K, Van Koeveringe G, Achten R, et al: Long-term clinical outcome of a diagnostic transurethral resection of the prostate in patients with an elevated prostate-specific antigen level and minor lower urinary tract symptoms. Urol Int (accepted for publication).

[72] van Renterghem K, Van Koeveringe G, Achten R, et al: Prospective study of the clinical outcome of a TURP in patients with an elevated prostate specific antigen level, minor 
lower urinary tract symptoms and proven bladder outlet obstruction. Eur Urol 2008;54(6):1385-1392.

[73] Eastham J, Kattan M, Fearn P, et al. Local progression among men with conservatively treated localized prostate cancer: results from the Transatlantic Prostate Group. Eur Urol 2008;53:347-354.

[74] Cheng L, Bergstralh EJ, Scherer BG, et al. Predictors of cancer progression in T1a prostate adenocarcinoma. Cancer. 1999;85:1300-1304.

[75] Aro AR, Pilvikki Absetz $S$, van Elderen TM, et al: False-positive findings in mammography screening induces short-term distress-breast cancer-specific concern prevails longer. Eur J Cancer 2000;26:1089-1097.

[76] Lipkus IM, Halabi S, Strigo TS, et al: The impact of abnormal mammograms on psychological outcomes and subsequent screening. Psycho-oncology 2000;9:402-410.

[77] Katz D, Jarrard D, McHorney C, et al: Health perceptions in patients who undergo screening and workup for prostate cancer. Urology 2007;69:215-220.

[78] Brawer MK, Lin DW, Williford WO, et al: Effect of Finasteride and/or Terazosin on serum PSA: results of VA cooperative study \#359. Prostate 1999;39:234-239.

[79] Pannek J, Marks LS, Pearson JD, et al: Influence of Finasteride on free and total serum prostate specific antigen levels in men with benign prostatic hyperplasia. J Urol 1998;159:449-453.

[80] Sacks SH, Aparicio SA, Bevan A, et al: Late renal failure due to prostatic outflow obstruction: a preventable disease. Br Med J 1989;298:156-159.

[81] Rule AD, Lieber MM, Jacobsen SJ. Is benign prostatic hyperplasia a risk factor for chronic renal failure? J Urol 2005;173:691-696.

[82] Teillac P and Scarpa RM: Economic issues in the treatment of BPH. Eur Urol 2006;S5:1018-1024.

[83] Saigal C and Joyce G: Economic costs of benign prostatic hyperplasia in the private sector. J Urol 2005;173:1309-1313.

[84] Disantostefano R, Biddle A, Lavelle J: An evaluation of the economic costs and patientrelated consequences of treatments for benign prostatic hyperplasia. BJU Int 2006;97:1007-1016. 
[85] Wendt-Nordahl G, Bucher B, Häcker A, et al: Improvement in mortality and morbidity in transurethral resection of the prostate over 17 years in a single center. J Endourol 2007;21(9):1081-1087.

[86] Rassweiler J, Teber D, Kuntz R, et al: Complications of transurethral resection of the prostate (TURP) - Incidence, management and prevention; Eur Urol 2006;50:969-980.

[87] Madersbacher S, Lackner J, Brössner C, et al: Reoperation, myocardial infarction and mortality after transurethral and open prostatectomy: a nation-wide, long term analysis of 23.123 cases. Eur Urol 2005;47:499-504.

[88] Reich O, Gratzke C, Stief CG: Techniques and long-term results of surgical procedures for BPH. Eur Urol 2006;49:970-978.

[89] Müntener M, Aellig S, Küttel R, et al: Peri-operative morbidity and changes in symptom scores after transurethral prostatectomy in Switzerland: results of an independent assessment of outcome. BJU Int 2006;98:381-383.

[90] Hakenberg OW, Pinnock CB, Marshall VR: Preoperative urodynamic and symptom evaluation of patients undergoing transurethral prostatectomy: analysis of variables for outcome. BJU Int. 2003;91(4):375-379.

[91] Rodrigues $P$, Lucon AM, Freire GC, et al: Urodynamic pressure flow studies can predict the clinical outcome after transurethral prostatic resection. J Urol 2001;165:499-502.

[92] Tanaka $\mathrm{Y}$, Masumori N, Itoh N, et al: Is the short-term outcome of transurethral resection of the prostate affected by preoperative degree of bladder outlet obstruction, status of detrusor contractility or detrusor overactivity? Int J Urol 2006;13:1398-1404.

[93] Seki N, Takei M, Yamaguchi A, et al: Analysis of prognostic factors regarding the outcome after transurethral resection for symptomatic benign prostatic enlargement. Neurourol Urodyn 2006;25(5):428-432. 
Chapter 7 - Summarizing discussion and conclusions 
In our Western society, characterised by an increasing ageing population with an improving general health and growing life expectancy, prostatic diseases are more and more frequently encountered. Both BPH and prostate cancer are diseases of the ageing male. For this reason it is not surprising that more and more men become "old enough" to be confronted with a prostatic disease. Since PSA was introduced, urologists had a very interesting diagnostic tool to investigate prostate conditions. Furthermore, it is important to notice a growing awareness of patients especially with the introduction of internet. Men do know and care about their health and in particular "their prostate". Most men are aware of the prevalence of BPH and especially prostate cancer, and above all, prostate cancer related death. This awareness introduced new "prostate related diseases" such as "PSA anxiety" [1].

Therefore, it is not surprising that many patients are referred to the urologists because of "prostatic symptoms" including LUTS, prostatitis, and suspicion of prostate cancer. This implicates that many men are referred to an urologist because of elevated PSA levels. For this reason, general practitioners and especially urologists will be frequently confronted with patients with elevated and/or rising PSA levels.

If PSA levels are elevated and/or rising and rectal examination and/or transrectal ultrasound are suspicious for prostate cancer which is then proven by positive extended prostate biopsies, many books and articles have been written about possible strategies to follow. If however PSA levels are elevated and/or rising, rectal examination and/or transrectal ultrasound are negative, patients do not show any or only minor symptoms and (multiple) extended prostate biopsies are negative for cancer, uncertainty will appear. Especially 
when prostate biopsies remain negative in repeated biopsies, we often do not know how to continue. One option would be to start an antibiotic treatment. However, real scientific evidence in this indication is lacking. Another option is to give dietary supplements, but also this strategy had not been scientifically proven. A third possibility is to give $\alpha 1$ blockers, although these compounds do not have an effect on the PSA level; consequently, they do not have an effect on symptoms since patients show minor symptoms only. Another possible therapy could be to start treatment with $5 \alpha$ reductase inhibitors, but in this case, the effect on the PSA levels is not always following the multiply by two rule; moreover this treatment will once again have no major symptomatical effect on patients with only minor LUTS. Another possibility could be to keep on performing biopsies on those patients. However, we do know that repeating biopsies is useful only to a certain extent; furthermore we might be looking for a cancer that is not present. In this group of patients it is obvious that uncertainty will grow.

In our first paper, we performed a retrospective analysis in patients with (1) no bothersome LUTS (International Prostate Symptoms Score [IPSS] 0-7 or 8-19); (2) elevated and/or rising PSA ( $\geq 4 \mathrm{ng} / \mathrm{ml}$ ); (3) normal rectal examination and/or normal transrectal ultrasound (4) and (multiple) negative prostate biopsies. In this study we have shown that BOO is most likely the reason of the elevated PSA value. We evaluated a group of 82 patients from January 1997 up to 2004. Three of the 82 patients $(4.1 \%)$ had a $P$ det $Q_{\max }$ with an equivocal value (20-40 $\mathrm{cm} \mathrm{H}_{2} \mathrm{O}$ ). However, the remaining 79 patients were clearly obstructed with Pdet $_{\max }>40 \mathrm{~cm} \mathrm{H}$ O (95.9\%) according to Abrams-Griffiths [2]. After demonstrating $\mathrm{BOO}$ in this group of patients, transurethral resection of prostate (TURP) revealed evidence of prostate cancer in 8 of the 82 patients 
(9.8\%), while only BPH was encountered in 74 of the 82 patients $(90.2 \%)$. In the clearly obstructed group a mean PdetQ ${ }_{\max }$ of $89.5 \mathrm{~cm} \mathrm{H}_{2} \mathrm{O}\left(20-200 \mathrm{~cm} \mathrm{H}_{2} \mathrm{O}\right)$ was measured. We concluded that there is a scientific basis for pressure flow studies in patients with elevated and/or rising PSA; minor LUTS; normal rectal examination and/or normal TRUS; (multiple) negative extended prostate biopsies and that pressure flow study will show all patients to be obstructed. For this reason we concluded that $\mathrm{BOO}$ was the reason of the elevated PSA value in this particular group of patients which was probably due to chronically elevated intravesical pressure.

In a second article we evaluated the results in the same group of 82 patients but with particular emphasis on TURP outcome. All of the 82 patients underwent TURP because of proven BOO. As already mentioned, 8 patients (9.8\%) appeared to have prostate cancer, while 74 patients $(90.2 \%)$ had $\mathrm{BPH}$. In this BPH group, the mean preoperative PSA value was $8.8 \mathrm{ng} / \mathrm{ml}$ (range 4.3$25.8 \mathrm{ng} / \mathrm{ml}$ ). Mean PSA values in this group of patients dropped to $1.1 \mathrm{ng} / \mathrm{ml}$ and $1.3 \mathrm{ng} / \mathrm{ml}$ after the first and second year after TURP, respectively. The same observation concerning IPSS evaluation before and after TURP was made. Seven of the 8 patients with prostate cancer had a clinical important and aggressive prostate cancer that needed further treatment. An interesting finding was that if radical prostatectomy was performed, residual prostate cancer was located mostly in the anterior and lateral peripheral zone. The conclusion of this paper was that PSA elevation in this particular group of patients was the result of $\mathrm{BOO}$ and that it can be treated with TURP. This procedure results in a (super)normalisation of PSA and normalisation of IPSS. Furthermore, TURP allows an extensive histological examination. 
In a third paper we evaluated the long term results of the same group of patients. In the retrospective group of 82 patients, 74 patients had BPH after TURP. Of these 74 patients, 36 patients were followed for more than 3 years (mean 62.1 months, range 38-103 months). During this follow-up period, one patient (2.8\%) presented with a new problem of PSA elevation that was caused by prostate cancer, proven by repeated prostate biopsies 4 years after TURP. In the radical prostatectomy specimen of this patient, a residual tumour in the anterior and lateral peripheral zone was shown. The other 35 patients (97.2\%) had a low and stable PSA value. More specifically, PSA had a mean value of 8.2 $\mathrm{ng} / \mathrm{ml}$ (range $4.2-15 \mathrm{ng} / \mathrm{ml}$ ) preoperatively; a mean value of $0.9 \mathrm{ng} / \mathrm{ml}$ (range 0.1-2.7 ng/ml) and $1.1 \mathrm{ng} / \mathrm{ml}$ (range 0.2-3.9 $\mathrm{ng} / \mathrm{ml}$ ) was obtained the first year after TURP and at the end of follow-up, respectively. The same observation could be made regarding the IPSS values. In this third paper we concluded that BOO will be encountered in this group of patients with those particular characteristics and that TURP will result in a long term normalisation of PSA and IPSS values. On the other hand, yearly monitoring remains necessary since in rare cases aggressive prostate cancer can be encountered.

In a fourth paper we performed a prospective analysis in a group of 33 patients with the same characteristics (elevated and/or rising PSA; minor LUTS; normal rectal examination and/or TRUS; (multiple) negative extended prostate biopsies). In this group of patients, the mean PSA was $8.2 \mathrm{ng} / \mathrm{ml}$ (range 5.1$16.4 \mathrm{ng} / \mathrm{ml}$ ) preoperatively. Additionally, PSA velocity, PSA ratio, PSA density, IPSS and $P_{\text {det }} \mathrm{max}_{\max }$ were evaluated. After TURP, only BPH was discovered in 27 patients (81.8\%) after TURP. In 2 patients (6.1\%), aggressive prostate cancer was encountered (taking into account the age of the subject, the Gleason score, and the amount of cancer cells). In 4 patients (12.1\%) only a few chips of 
unaggressive prostate cancer were encountered. The patients with pure BPH and unaggressive cancer were subjected to close surveillance $(81.8 \%+12.1 \%=$ 93.9\%). In this close surveillance group, PSA dropped with a mean value of 0.6 $\mathrm{ng} / \mathrm{ml}$, postoperatively. On the other hand, radical retropubic prostatectomy performed in patients with aggressive prostate cancer proved again residual tumour in the lateral and anterior peripheral prostate. In conclusion, this means that the prospective analysis confirmed the retrospective results.

In a fifth and final paper, we made a proposal for a new algorithm to treat these patients. After an overview of the current strategies in patients with those characteristics (elevated and/or rising PSA; minor LUTS; normal rectal examination and/or TRUS; (multiple) negative extended prostate biopsies), we focused on the value of urodynamic investigation with regard to BOO. Instead of antibiotic treatment, dietary intervention and repeated prostate biopsies, performing a TURP should be discussed with those patients. Besides treating $\mathrm{BOO}$, other arguments in favour of performing a TURP are: a (super)normalisation of PSA, an improvement of IPSS and quality of life, and the possibility to perform extensive histological examination that can show in a few cases potentially life threatening and curable prostate cancer. In this perspective TURP can be considered as a "diagnostic TURP".

Altogether, we have shown in this thesis that these patients are very suspicious of having BOO, implying that an urodynamic evaluation is useful in this particular group. One should know that this is not really surprising since we know that in patients with LUTS, an elevated PSA level is a marker for BOO. Furthermore it is a predictor of future prostate growth, a marker for risk of 
acute urinary retention and well correlated with an elevated need for surgical therapy.

If urodynamic investigation proves BOO, a TURP should be discussed with the patient. The first advantage of this strategy is that PSA will drop dramatically. This will of course take away the uncertainty and proves that BOO was the major cause of elevated PSA levels. Another argument in favour of TURP is subjective improvement of the patient with regard to IPSS and/or quality of life score. Even in patients with "minor LUTS", symptoms can improve. When using symptom scores, caution is required as they are a very subjective tool in assessing symptomatology. For this reason, symptom scores are more useful to monitor treatment over time rather than to assess the severity of the symptoms. Furthermore, the fact that PSA levels "super"normalise without histological evidence of prostate cancer represents a symptomatic benefit in this group of patients.

On the other hand a "diagnostic" TURP implicates that prostate cancer can be encountered in the resected tissue by histological examination. This should be well explained to the patient because in some cases we will diagnose a potentially life threatening and curable prostate cancer. In this perspective we do know that even after TURP, radical prostatectomy can be executed without major complications.

Moreover, we know that if $\mathrm{BOO}$ is not treated, this can end in conditions such as detrusor fatigue and postrenal kidney insufficiency. 
Arguments in favour of a performing TURP instead of starting medical treatment is the fact that we know that $\alpha 1$ blockade has no effect on PSA and $5 \alpha$ reductase inhibitors have a heterogeneous effect. Furthermore, these patients suffer from minor LUTS only. If no TURP is performed, we do not have any histology to explain the elevated PSA values. Moreover the economic aspect needs to be taken into account since medical treatment will mostly only postpone the surgical treatment of a chronic disease in an ageing population.

Histological examination showed that an anterior resection in TURP is vital. We do know that (multiple) extended prostate biopsies are false negative in this group of patients because the tumour is mainly located laterally or anteriorly in the peripheral zone, which is difficult to reach with a biopsy needle.

In conclusion, patients with (1) elevated and/or rising PSA; (2) minor LUTS; (3) negative rectal examination and/or transrectal ultrasound and (4) (multiple) negative extended prostate biopsies are a challenging problem for urologists. So far we had no answer to explain these PSA values and to reassure those patients. We proved that those patients are very likely to have BOO for which a TURP should be discussed since this will result in a "super"normalisation of PSA and a symptomatic benefit for the patient, and allows extensive histological examination. 


\section{References}

[1] Roth A, Nelson CJ, Rosenfeld B, Warshowski A, O'Shea N, Scher H, Holland JC, Slovin S, Curley-Smart T, Reynolds T, Breitbart W. Assessing anxiety in men with prostate cancer: further data on the reliability and validity of the memorial anxiety scale for prostate cancer (MAX-PC). Psychosomatics 2006;47(4):340-347.

[2] Griffiths D, Höfner K, van Mastrigt R, Rollema HJ, Spangberg A and Gleason D. Standardization of terminology of lower urinary tract function: Pressure-flow studies of voiding, urethral resistance, and urethral obstruction. Neurourol Urodyn 1997;16:1-18. 
Chapter 8 - Samenvatting, bespiegeling en conclusies 
Onze westerse maatschappij wordt gekenmerkt door een toename van de vergrijzing en dit samen met een verbetering van de algemene gezondheid en toenemende levensverwachting. Dit impliceert dat prostaataandoeningen steeds frequenter zullen voorkomen. Het is genoegzaam bekend dat BPH (goedaardige prostaat vergroting) en prostaatkanker ziektes zijn van de ouder wordende man (Ageing Male). Het is dan ook niet verwonderlijk dat mannen steeds meer "oud genoeg worden" om geconfronteerd te worden met een of andere prostaataandoening. Na de introductie van een nieuwe prostaattumor merker, prostaat specifiek antigeen (PSA), hadden urologen een zeer interessant werkinstrument om prostaataandoeningen verder te onderzoeken. Ook de toenemende bewustwording bij patiënten, in het bijzonder na de introductie van internet, heeft ervoor gezorgd dat er een groeiende bewustmaking is van allerlei gezondheidsbedreigende situaties en dus ook meer in bijzonder van prostaataandoeningen bij mannen. Mannen zijn dan ook vandaag de dag op de hoogte van, en bezorgd om hun algemene gezondheid en in het bijzonder "hun prostaat". Heel wat mannen zijn zich bewust van het frequent voorkomen van goedaardige prostaatvergroting (BPH) en in het bijzonder van prostaatkanker en zeker ook van door prostaatkanker veroorzaakte overlijdens. Dit bewustzijn introduceerde dan ook nieuwe "prostaat gerelateerde ziekten" zoals "PSA-itis, PSA angst" etc [1].

Om deze redenen mag het dan ook niet verwonderlijk zijn dat heel wat patiënten verwezen worden naar de uroloog omwille van "prostaat symptomen" zoals prostatisme klachten (LUTS), prostatitis symptomatologie en verdenking op prostaatkanker. Dit impliceert dan ook dat heel wat mannen verwezen worden naar een uroloog omwille van een verhoogd en/of oplopend PSA. Uit het bovengaande kan dan ook afgeleid worden dat huisartsen en in 
het bijzonder urologen frequent geconfronteerd zullen worden met patiënten met verhoogde en/of oplopende PSA waarden.

Als het PSA gehalte verhoogd is en/of oplopend en rectaal prostaatonderzoek en/of transrectale prostaatechografie verdacht zijn voor prostaatkanker en wanneer prostaatkanker aangetoond wordt door middel van prostaatbiopten, zijn er heel wat boeken en publicaties geschreven met betrekking tot mogelijke strategieën die gevolgd kunnen worden. Als daarentegen het PSA gehalte verhoogd en/of oplopend is, rectaal prostaatonderzoek en/of transrectale prostaatechografie geen verdenking voor prostaatkanker geven en wanneer patiënten weinig tot geen klachten hebben en wanneer tenslotte (herhaalde) uitgebreide prostaatbiopten geen kanker laten zien, zal onzekerheid de kop op steken. Zeker wanneer prostaatbiopten negatief blijven bij herhaling wordt het op de duur moeilijk om te beslissen hoe het nu verder moet. Een optie zou kunnen zijn het opstarten van een antibiotische behandeling, we moeten echter opmerken dat hiervoor tot op heden geen echt wetenschappelijk bewijs geleverd is. Een andere optie is het adviseren van dieetmaatregelen en/of voedingssupplementen. Ook deze strategie is tot op heden niet wetenschappelijk bewezen. Een andere mogelijkheid is het geven van een medicamenteuze behandeling met een $\alpha 1$-blokker. Hiervan is geweten dat deze geen effect hebben op het PSA gehalte en uiteraard ook weinig effect op de symptomatologie aangezien deze patiënten gekarakteriseerd worden door weinig tot geen symptomatologie. Ook het opstarten van een behandeling met $5 \alpha$-reductase remmers kan overwogen worden. In dit geval is het belangrijk op te merken dat het PSA gehalte zeker zal dalen maar dat de "vermenigvuldig x2" regel bijlange niet altijd opgaat. Ook hier weer zal de behandeling weinig tot geen symptomatisch voordeel opleveren aangezien de populatie patiënten weinig tot geen klachten heeft. Ook het steeds weer opnieuw uitvoeren van 
nieuwe biopten kan bij deze patiënten overwogen worden. Herhalen van biopten ad eternam is echter niet zinvol, temeer daar we misschien op zoek gaan naar een kanker die niet bestaat. Het hoeft dan ook geen betoog dat in deze groep van patiënten onzekerheid en ongerustheid zullen toenemen.

In een eerste publicatie werd een retrospectieve analyse uitgevoerd bij patiënt met volgende karakteristieken:

1) geen storende symptomatologie (LUTS, international prostate symptoms score (IPSS) 0-7 of 8-19),

2) verhoogd en/of oplopend PSA (meer of gelijk aan $4 \mathrm{ng} / \mathrm{ml}$ ),

3) normaal rectaal prostaatonderzoek en/of normaal transrectaal echografisch onderzoek van de prostaat,

4) (veelvuldige) negatieve prostaatbiopten.

In dit onderzoek hebben we kunnen aantonen dat de meest waarschijnlijke oorzaak van het verhoogd PSA infravesicale obstructie is. Tweeëntachtig patiënten met deze karakteristieken werden geëvalueerd vanaf januari 1997 tot eind 2004. Drie van deze 82 patiënten $(4,1 \%)$ hadden een $P \operatorname{det} Q_{\max }$ (blaasdruk op het moment van maximaal straaldebiet) met een waarde van 20$40 \mathrm{~cm} \mathrm{H} \mathrm{H}_{2} \mathrm{O}$, hetgeen een intermediare waarde is. Daarentegen hadden de 79 overige patiënten een zuivere obstructie met een $P d e t Q_{\max }$ van meer dan 40 $\mathrm{cm} \mathrm{H}_{2} \mathrm{O}(95,9 \%)$ en dit volgens de Abrams-Griffiths criteria [2]. Nadat bij deze patiënten infravesicale obstructie was aangetoond, toonde histologisch onderzoek van het prostaatweefsel na transurethrale prostaatresectie (TURP), de aanwezigheid van prostaatkanker in 8 van deze 82 patiënten $(9,8 \%)$. Daarentegen werd er bij 74 van de 82 patiënten enkel goedaardige prostaatvergroting (BPH) aangetroffen (90,2\%). In de zuiver obstructieve groep vonden we een $P_{d e t} Q_{\max }$ van gemiddeld $89,5 \mathrm{~cm} \mathrm{H}_{2} \mathrm{O}\left(20-200 \mathrm{~cm} \mathrm{H}_{2} \mathrm{O}\right)$. We concludeerden dan ook dat er een wetenschappelijke basis bestaat voor het 
uitvoeren van een cystometrie met een pressure flowstudie (blaasdruk versus mictiestraal) bij patiënten met de bovengenoemde kenmerken:

1) verhoogd en/of oplopend PSA,

2) geen uitgesproken mictieklachten,

3) normaal rectaal onderzoek en/of normaal transrectaal prostaatechografisch onderzoek,

4) (veelvuldige) negatieve prostaatbiopten.

Dit onderzoek toonde aan dat alle patiënten met deze karakteristieken lijden aan infravesicale obstructie. Om deze reden werd dan ook geconcludeerd dat infravesicale obstructie de oorzaak was van het verhoogde PSA in patiënten met hoger genoemde criteria, hetgeen meest waarschijnlijk zijn oorsprong vindt in een chronisch verhoogde intravesicale druk.

In een tweede artikel werden de resultaten geëvalueerd van dezelfde groep van 82 patiënten met ditmaal bijzondere aandacht voor de uitkomst van de uitgevoerde TURP. Alle 82 patiënten ondergingen inderdaad een TURP omwille van bewezen infravesicale obstructie. Zoals hierboven vermeld werd bij 8 patiënten $(9,8 \%)$ prostaatkanker aangetroffen, daarentegen hadden 74 patiënten $(90,2 \%)$ enkel $\mathrm{BPH}$. In deze BPH groep bedroeg de gemiddelde preoperatieve PSA waarde $8,8 \mathrm{ng} / \mathrm{ml}(4,3-25,8 \mathrm{ng} / \mathrm{ml})$. De gemiddelde PSA waarden in deze groep daalden tot $1,1 \mathrm{ng} / \mathrm{ml} 1$ jaar na TURP en tot gemiddeld $1,3 \mathrm{ng} / \mathrm{ml}$ het tweede jaar na de TURP. Ook naar symptomatologie toe kon met de IPSS schaal een gelijkaardige conclusie getrokken worden. Zeven van de 8 patiënten waarbij prostaatkanker aangetroffen werd, hadden een klinisch belangrijke en agressieve prostaatkanker met karakteristieken die een verdere behandeling noodzakelijk maakten. Indien in deze groep een radicale prostatectomie werd uitgevoerd, was het frappant de resterende tumor 
telkens in hoofdzaak anterieur en lateraal in de perifere prostaatzone aan te treffen. De conclusie van deze publicatie was dat de PSA verhoging in deze groep van patiënten met deze kenmerken het resultaat was van infravesicale obstructie en dat wanneer de obstructie behandeld werd met een TURP dit leidde tot een (super) normalisatie van het PSA evenals een normalisatie van de symptomatologie (IPSS). Even belangrijk daarentegen was dat door de endoscopische prostaatresectie een uitgebreider histologisch mogelijk was.

In een derde publicatie werden de lange termijn resultaten van deze zelfde groep geanalyseerd. In onze retrospectieve groep van 82 patiënten waren er 74 patiënten met enkel goedaardige prostaatvergroting (BPH) na TURP. Van deze 74 patiënten waren er 36 met een opvolgperiode van meer dan 3 jaar (gemiddeld 62,1 maanden, 38-103 maanden). Tijdens deze opvolgperiode was er 1 patiënt die zich opnieuw met een persisterend oplopend PSA presenteerde $(2,8 \%)$. Dit bleek na controle biopten 4 jaar na TURP te wijten aan een onderliggend prostaatcarcinoom. Deze patiënt onderging een radicale prostatectomie waarbij andermaal de residuele tumor zich in hoofdzaak anterieur en lateraal in de perifere zone situeerde. De andere 35 patiënten $(97,2 \%)$ hadden een stabiel en laag PSA gehalte tijdens de opvolgperiode. Meer precies bedroeg het PSA gemiddeld $8,2 \mathrm{mg} / \mathrm{ml}$ preoperatief $(4,2-15 \mathrm{ng} / \mathrm{ml})$ met een gemiddelde waarde van $0,9 \mathrm{ng} / \mathrm{ml}(0,1-2,7 \mathrm{ng} / \mathrm{ml})$ na 1 jaar en $1,1 \mathrm{ng} / \mathrm{ml}$ $(0,2-3,9 \mathrm{ng} / \mathrm{ml})$ op het einde van de opvolgperiode. Dezelfde observatie werd bekomen met betrekking tot de IPSS waarden. In dit derde artikel concludeerden we dat infravesicale obstructie in een specifieke groep van patiënten met bovenvermelde karakteristieken aangetroffen zal worden en dat een TURP zal resulteren in een langdurige normalisatie van het PSA en van de symptomatologie. Daarentegen blijft een jaarlijkse evaluatie noodzakelijk 
aangezien in zeldzame gevallen toch nog steeds een agressieve prostaatkanker aangetroffen kan worden.

In een vierde publicatie werd een prospectieve analyse uitgevoerd bij 33 patiënten met dezelfde karakteristieken: oplopend en/of stijgend PSA, beperkte symptomatologie, normaal rectaal prostaatonderzoek en/of transrectale prostaatechografie, (veelvuldige) negatieve prostaatbiopten. In deze groep van patiënten was de gemiddelde PSA waarde 8,2 ng/ml (5,1-16,4 $\mathrm{ng} / \mathrm{ml}$ ) bij de preoperatieve bepaling. Bij deze patiënten werd ook een analyse uitgevoerd van de PSA velocity, PSA ratio, PSA density, IPSS score en Pdet $Q_{\max }$. Na TURP werd bij 27 patiënten (81,8\%) enkel BPH aangetroffen. In 2 patiënten $(6,1 \%)$ werd een agressieve, levensbedreigende prostaatkanker aangetroffen. In 4 patiënten $(12,1 \%)$ werd alleen in paar chips een niet levensbedreigende prostaatkanker aangetroffen. Patiënten met zuivere BPH en een niet agressieve prostaatkanker werden gevolgd met een nauwgezet opvolgbeleid $(81,8 \%+$ $12,1 \%=93,9 \%)$. In deze "nauwgezette opvolggroep" zakte het PSA tot een gemiddelde waarde van $0,6 \mathrm{ng} / \mathrm{ml}$ na de TURP. Bij de 2 patiënten met een levensbedreigende prostaatkanker werd een radicale prostatectomie uitgevoerd waarbij eens te meer de residuele tumor gelokaliseerd was lateraal en anterieur in de perifere prostaatzone. Dit betekent dan ook dat onze prospectieve analyse de retrospectieve resultaten kon vestigen.

In een vijfde en finaal onderzoek werd een voorstel uitgewerkt voor een nieuw algoritme om deze patiënten te behandelen. Na een overzicht van de actuele strategieën bij patiënten met deze typische karakteristieken (verhoogd en/of oplopend PSA, beperkte symptomatologie,. normaal rectaal prostaatonderzoek en/of transrectale prostaatechografie, (veelvuldige) negatieve prostaatbiopten 
werd gefocuseerd op de waarde van urodynamisch onderzoek met betrekking tot infravesicale obstructie. In plaats van "antibioticabehandeling", "dieetmaatregelen", nieuwe prostaatbiopten, stellen wij voor een TURP met deze patiënten te bespreken. Argumenten pro-TURP zijn behoudens het behandelen van infravesicale obstructie, een te verwachten "super" normalisatie van het PSA, een verbetering van de symptomatologie en levenskwaliteit en de mogelijkheid om uitgebreid histologisch onderzoek uit te voeren hetgeen in een aantal gevallen een potentieel levensbedreigende en curabele prostaatkanker zal aantonen. Vanuit dit oogpunt kan deze TURP dan ook beschouwd worden als een "diagnostische TURP".

In deze dissertatie werd dan ook aangetoond dat patiënten met deze karakteristieken sterk verdacht zijn op het hebben van infravesicale obstructie hetgeen impliceert dat een urodynamisch onderzoek aangewezen is in deze particuliere groep. In deze context noteren we dat uiteraard ook bij patiënten met LUTS klachten een verhoogde PSA waarde kan gezien worden als een merker voor infravesicale obstructie. Tevens voorspelt deze verhoogde PSA waarde bij symptomatische patiënten een verhoogde kans op toekomstige prostaatgroei, een verhoogde kans op acute urineretentie en een verhoogde nood aan chirurgische behandeling van deze obstructie. Als het urodynamisch onderzoek in deze particuliere groep infravesicale obstructie kan aantonen, zou een TURP met deze patiënten moeten besproken worden. Het eerste voordeel van deze strategie is dat het PSA dramatisch zal zakken. Dit zal dan ook de onzekerheid bij patiënten, huisarts en uroloog wegnemen en bevestigen dat infravesicale obstructie de belangrijkste oorzaak was van de verhoogde PSA waarde. Ook de subjectieve verbetering bij de patiënt met betrekking tot de IPSS score en levenskwaliteit is een argument pro TURP. Ook patiënten met 
"weinig klachten" kunnen verbeteren. Het is in dit verband ook belangrijk op te merken dat symptoomscores met de nodige omzichtigheid moet geïnterpreteerd worden. Deze zijn een zeer subjectief middel om symptomatologie te kwantificeren. Om deze reden zijn symptoomscores dan ook veel interessanter om een behandeling over de tijd te volgen eerder dan om de ernst van de klachten te evalueren. Vermelden we dat ook het "super"normaliseren van PSA zonder aanwezigheid van prostaatkanker bij histologisch onderzoek een symptomatisch voordeel betekent bij deze patiënten.

De term "diagnostisch TURP" impliceert echter dat ook prostaatkanker bij deze patiënten kan aangetroffen worden na histologisch onderzoek van het gereseceerde prostaatweefsel. Dit moet dan ook met de patiënt besproken worden voor de ingreep aangezien bij een aantal patiënten op die manier een potentieel levensbedreigende maar geneesbare prostaatkanker zal aangetroffen worden. In dit perspectief is het dan ook goed te weten dat een radicale prostatectomie zonder al te grote moeilijkheden even succesvol kan uitgevoerd worden bij patiënten na TURP.

Verder is het ook genoegzaam bekend dat wanneer een infravesicale obstructie niet behandeld wordt, deze kan leiden tot o.a. detrusor decompensatie met hypocontractiliteit en postrenale nierinsufficiëntie. Men kan zich ook de vraag stellen waarom deze patiënten niet medicamenteus behandeld kunnen worden. Wanneer we met een a1-blokker starten, weten we dat deze geen effect zal hebben op het PSA. Een $5 \alpha$-reductase remmer heeft daarentegen een heterogeen effect op de PSA waarde. Noteren we in dit verband ook dat deze patiënten enkel beperkte mictie klachten hebben. Tenslotte zal alleen een TURP uitgebreid histologisch onderzoek toelaten. Ook economische 
argumenten moeten in overweging genomen worden aangezien in de meeste gevallen deze medicamenteuze behandelingen enkel een chirurgische behandeling zullen uitstellen bij een chronische ziekte in een steeds ouder wordende populatie.

Het histologisch onderzoek na TURP toonde verder aan dat een anterieure resectie van zeer groot belang is. We weten evenens dat prostaatbiopten vals negatief kunnen zijn omdat bij deze groep van patiënten de tumor meestal lateraal en/of anterieur in de perifere zone gelokaliseerd is, een gebied moeilijk adequaat te bereiken met een biopsienaald.

Concluderend kan men stellen dat bij patiënten met

1) verhoogd en/of oplopend PSA,

2) beperkte mictieklachten,

3) negatief rectaal prostaatonderzoek en/of transrectale prostaatechografie, en

4) (veelvuldige) negatieve prostaatbiopten

de te volgen strategie niet altijd eenduidig is. Deze patiënten zijn dan ook een uitdaging in de urologische praktijk. Tot op heden hadden we geen duidelijke verklaring om deze PSA verhoging uit te leggen om deze patiënten gerust te stellen. We hebben kunnen aantonen dat patiënten met deze karakteristieken zeer waarschijnlijk infravesicale obstructie hebben waarvoor een TURP zou moeten overwogen worden, dit omwille van een te verwachten "super" normalisatie van het PSA, het symptomatische voordeel en de mogelijkheid van een uitgebreid histologisch onderzoek. 


\section{Referenties}

[1] Roth A, Nelson CJ, Rosenfeld B, Warshowski A, O'Shea N, Scher H, Holland JC, Slovin S, Curley-Smart T, Reynolds T, Breitbart W. Assessing anxiety in men with prostate cancer: further data on the reliability and validity of the memorial anxiety scale for prostate cancer (MAX-PC). Psychosomatics 2006;47(4);340-347.

[2] Griffiths K, Höfner K, van Mastrigt R, Rollema HJ, Spangber A and Gleason D. Standardization of terminology of lower urinary tract function: Pressure-flowstudies of voiding, urethral resistance, an urethral obstruction. Neurourol Urodyn 1997;16:118.Arrighi HM, Metter EJ, Guess HA, Fozzard JL. Natural history of benign prostatic hyperplasia and risk of prostatectomy, the Baltimore Longitudinal Study of Aging. Urology 1991;35(Suppl):4-8. 


\section{Dankwoord}

Velen ben ik dankbaar, en zeker de volgende mensen.

Vooreerst dank ik oprecht en hartelijk mijn promotor, Professor Dr. Phillippe E.V.A. van Kerrebroeck, hoofd afdeling urologie van het Academisch Ziekenhuis Maastricht en hoogleraar aan de Universiteit Maastricht. Ik ken hem al geruime tijd, maar wat hij wellicht niet meer weet, is dat ik al in 1991 op aangeven van mijn leermeester destijds, Dr. Johan Mattelaer, een urodynamische opleiding volgde bij hem in Nijmegen. Een paar jaar later kwam ik opnieuw mede in zijn kundige handen terecht, ditmaal als laatstejaarsassistent in de dienst urologie van het Universitair Ziekenhuis Sint-Radboud te Nijmegen, waar hij toen staflid was. Uiteindelijk werden we "buren". Ik dank hem zeer omdat hij met me wilde samenwerken en bereid gevonden werd promotor te worden van dit proefschrift. Hij was inderdaad pro-motor.

Ook Dr. Gommert A.van Koeveringe, staflid afdeling urologie van het Academisch Ziekenhuis Maastricht en co-promotor verdient mijn bijzondere dank omdat hij veel tijd besteedde aan dit project. Zijn inbreng en zeer degelijke en goed onderbouwde opmerkingen waren onmisbaar voor de realisatie van dit proefschrift.

Ik dank de leden van de jury die de tijd vonden hun kritische blik te laten gaan over dit proefschrift, in het bijzonder Professor Dr. Adriaan P. de Bruïne, Professor Dr. Onno van Schayck, Professor Dr. Viviane C.G. Tjan-Heijnen en Professor Dr. Jean J.M.C.H de la Rosette en die bereid waren de examencommissie voor dit proefschrift te vervoegen. 
Ik dank de leden van de corona, Professor Dr. Frans M.J. Debruyne, Prof. Dr. Jack Schalken, Prof. Dr. Dirk Deridder en Prof. Dr. Gerasimos Alivizatos. Ik ben vereerd dat zij niettegenstaande hun drukke eigen klinische en wetenschappelijke activiteiten, dit proefschrift mee wilden beoordelen.

Een bijzonder woord van dank gaat uit naar mijn leermeesters. In de eerste plaats dank ik Professor Dr. Hein Van Poppel, diensthoofd dienst urologie van het Universitair Ziekenhuis van de Katholieke Universiteit te Leuven, in deze functie voorafgegaan door Professor Dr. Luc Baert, die ik eveneens oprecht dank voor het feit dat hij mij de toegang verleende tot het beroep van specialist uroloog. Ik dank hen voor de grondige, degelijke en diepgaande opleiding en het feit dat ik onder hun hoede tot erkend specialist in de urologie kon doorgroeien. Ik dank Professor Dr. Frans Debruyne, emeritus hoogleraar en ere-diensthoofd van de dienst urologie van het Academisch Ziekenhuis SintRadboud Universiteit Nijmegen. Hij was in mijn Nijmeegse tijd, en nu nog, ons "venster op de wereld". Ik dank Professor Dr. Jean de la Rosette en Professor Dr. Pilar Laguna van de Universiteit van Amsterdam en, nogmaals, Professor Dr. Gerasimos Alivizatos van de Dienst Urologie van de University of Athens voor hun steun en opbouwende kritiek tijdens de totstandkoming van dit proefschrift. Zoals Professor Dr. de la Rosette het mooi samenvatte, streek hij soms "zachte zalf over de diepe wonde".

Ik dank voorts Dr. Johan Mattelaer en Dr. Ignace Billiet, urologen te Kortrijk, waar ik mijn eerste stappen in de urologie verder vervolmaakte. Eveneens dank ik Dr. Victor Paul Nolens, chirurg in het Virga Jesseziekenhuis te Hasselt, die mij in de heelkunde op weg hielp. 
Ik dank tevens de Universiteit Maastricht, de Heer Rector Magnificus Prof. mr. Gerard P.M.F. Mols, de Heer Decaan Professor Dr. Martin Paul en de Heren en Dames Professoren Hoogleraren van de Faculteit Geneeskunde, voor de kans die ik kreeg en het voorrecht vandaag te mogen promoveren in dit huis. Verder dank ik mijn Alma Mater, de Katholieke Universiteit Leuven, en de Heren en Dames Professoren Hoogleraren van de Faculteit Geneeskunde die mij inwijdden in de opdracht doctor in de genees-, heel- en verloskunde te zijn.

Ik dank Dr. Ruth Achten, anatoompatholoog in het Virga Jesseziekenhuis te Hasselt, die een grote bijdrage leverde aan het tot stand komen van dit proefschrift door haar histopathologische protocols en door haar oordeelkundig mee nadenken.

Ik dank mijn collega's urologen van het Virga Jesseziekenhuis, toekomstig Jessaziekenhuis, en de leden collega's van de maatschap "Kliniek voor Urologie" die door hun inzicht en toewijding het samenwerken aangenaam maken. In het bijzonder dank ik Dr. Peter Martens die mij onderweg aanmoedigde en steunde en tevens aanvaardde paranymph te zijn. Ik dank het Virga Jesseziekenhuis, haar bestuursorganen en alle medewerkers.

Een uitdrukkelijk en hartelijk woord van dank gaat uit naar Dr. Sven Deferme voor onze diepgaande discussies, voor zijn opmerkingen, die van onschatbare waarde bleken en voor zijn onmiskenbare steun. Ik dank ook van harte de heer Michel Dispaux. 
Ik dank tevens onze secretaresses, in het bijzonder mevrouw An Motmans, met wiens kundige hulp dit werk keurig op schrift gesteld raakte. Ik dank eveneens mevrouw Greet Loix en mevrouw An Vander Mierde, leden van de secretariaatsploeg van de maatschap "Kliniek voor Urologie" werkzaam in de vestiging Laegveld aan de Luikersteenweg te Hasselt. Een woord van dank richt ik tot de verpleegkundigen van de maatschap, de dames Annick Henno, Ilse Evens, Nathalie Heselmans, Nathalie Kielbasa en Sigrid Steegmans. Dat geldt ook voor de heer hoofdverpleegkundige Dirk Baert en alle verpleegkundigen van de verpleegafdeling B3 en het operatiekwartier urologie van het Virga Jesseziekenhuis.

Verder bedank ik mijn naasten, mijn lieve moeder, mevrouw Estella Pyfferoen, mijn schoonmama, mevrouw Dr. Marie-Renée Vanderkerken-Vancauwenberghe en mijn schoonpapa, Dr. Guy Vanderkerken, voor hun uren en uren hulp, voor hun levenswijsheid en hun goede raad. Ik dank tevens mijn familie te Brugge, en mijn schoonbroers en -zusjes, de heer en mevrouw Jim en Annick Vanderkerken-Degroeve, en de heer en mevrouw Dr. Jan Vanderkerken, ook mijn paranymph, en Dr. Tine Vanderkerken-Decraene en mevrouw Catherine Vandermeersch. Dank ook aan mijn petekinderen, Sophie van Renterghem en Toon Seghers. Ik gedenk mijn grootouders die mij bij leven leerden dat er meer in het leven is dan studeren alleen, en mijn jongste schoonzusje Sophie Vanderkerken $\left({ }^{\dagger}\right)$ die ons allen vreugde bracht. 
Als allerlaatsten, dank aan mijn "team" ! Dankjewel aan mijn allerliefste echtgenote, Caroline Vanderkerken, mijn ultieme steun en toeverlaat. Zonder haar was dit niet mogelijk. Zij gaf het goede voorbeeld, promoveerde zelf op een proefschrift tot doctor in de rechten en moedigde mij vervolgens aan om hetzelfde te doen in mijn vakgebied. Ze heeft me vanaf het begin onvoorwaardelijk gesteund. Ook mijn allerliefste kinderen Victoria, Alexander, Laurens en Marie-Sophie van Renterghem bedank ik voor hun warme liefde. Aan hen draag ik dit werk op. Alles voor jullie!

Absque labore nihil

Koenraad M.L.E. van Renterghem 


\section{Curriculum Vitae}

Personalia:

Geboren: $\quad$ 06/05/1962

Geboorteplaats: Tielt - West Vlaanderen - België

Burgerlijke staat: gehuwd met Caroline Vanderkerken

4 kinderen: $\quad$ Victoria (04/12/1994), Alexander (06/06/1997), Laurens (19/11/1999), Marie-Sophie (05/07/2004)

Opleiding:

1968-1974:

Lagere school Sint-Lodewijkscollege Brugge.

1974-1979:

Lager secundair onderwijs richting Latijn-Wiskunde, SintLodewijkscollege Brugge.

1977-1980: Hoger secundair onderwijs, richting Latijn-Wetenschappen, Sint-Lodewijkscollege Brugge.

1980-1983: Kandidaturen genees-, heel- en verloskunde, Katholieke Universiteit Leuven, afdeling Kortrijk.

1983-1987: $\quad$ Doctoraten genees-, heel- en verloskunde, Katholieke Universiteit Leuven.

1987-1989: $\quad$ Opleiding algemene heelkunde, Virga Jesse Ziekenhuis, Hasselt, Dr. Victor Paul Nolens.

1989-1990: $\quad$ Opleiding urologie, Katholieke Universiteit Leuven, Prof Luc Baert - Prof Hendrik Van Poppel.

1990-1992: $\quad$ Opleiding urologie, Sint-Maartensziekenhuis, Kortrijk, Dr. Johan Mattelaer en Dr. Ignace Billiet.

1992-1993: Opleiding urologie Academisch Ziekenhuis Sint-Radboud, Nijmegen, Nederland, Professor Frans Debruyne.

Sinds 01/08/1993 uroloog in het Virga Jesse Ziekenhuis te Hasselt met bijzondere interesse voor de andrologie, uro-oncologie, benigne prostaat hyperplasie.

Lid van

Erkenningscommisie urologie Nederlandstalige kamer. Medische raad Virga Jesse ziekenhuis.

EORTC (European organisation for research and treatment of cancer).

FEBU (Fellow of the European board of Urology).

Hogere opleiding barokfluit en instrumentaal ensemble, Conservatorium Hasselt. 